\title{
Summary of Uranium Solubility Studies in Concrete Waste Forms and Vadose Zone Environments
}

\author{
EC Golovich \\ DM Wellman \\ RJ Serne \\ CC Bovaird
}

September 2011

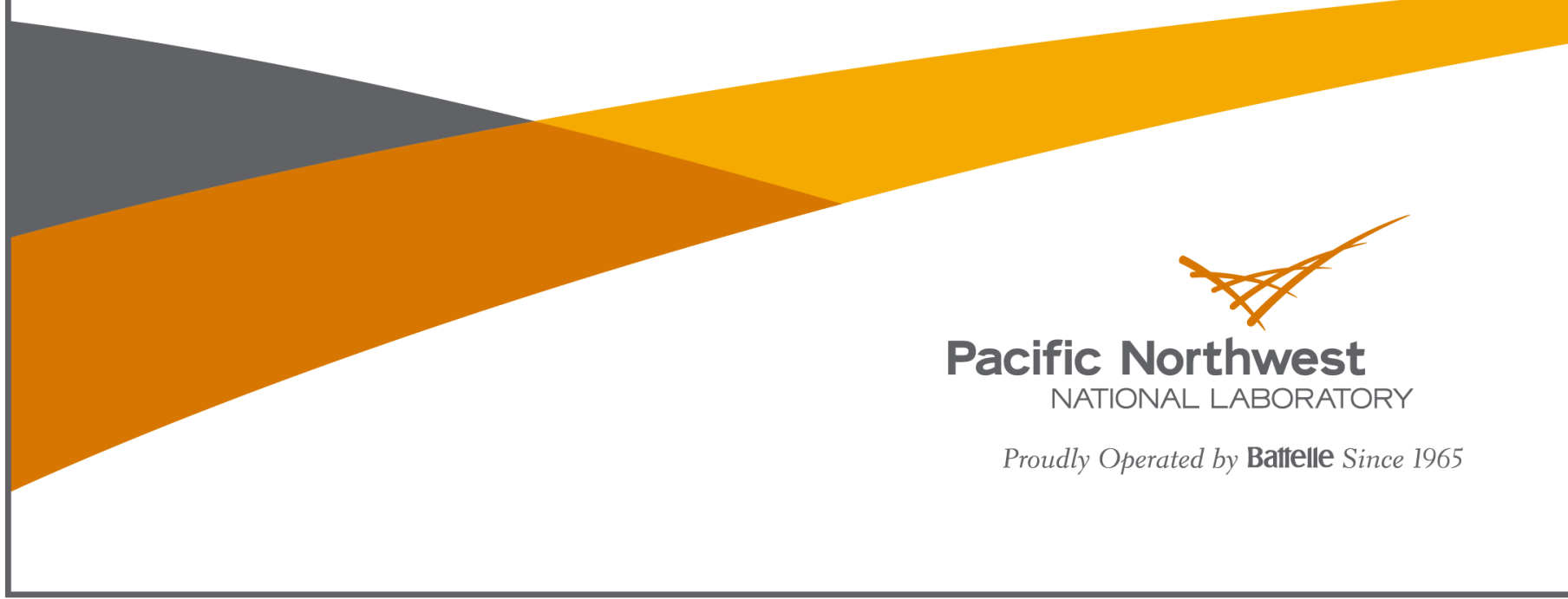




\section{DISCLAIMER}

This report was prepared as an account of work sponsored by an agency of the United States Government. Neither the United States Government nor any agency thereof, nor Battelle Memorial Institute, nor any of their employees, makes any warranty, express or implied, or assumes any legal liability or responsibility for the accuracy, completeness, or usefulness of any information, apparatus, product, or process disclosed, or represents that its use would not infringe privately owned rights. Reference herein to any specific commercial product, process, or service by trade name, trademark, manufacturer, or otherwise does not necessarily constitute or imply its endorsement, recommendation, or favoring by the United States Government or any agency thereof, or Battelle Memorial Institute. The views and opinions of authors expressed herein do not necessarily state or reflect those of the United States Government or any agency thereof.

\section{PACIFIC NORTHWEST NATIONAL LABORATORY operated by \\ BATTELLE for the UNITED STATES DEPARTMENT OF ENERGY under Contract DE-AC05-76RL01830}

Printed in the United States of America

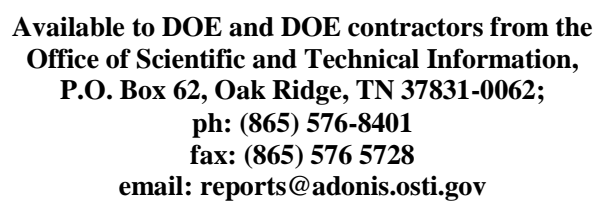

Available to the public from the National Technical Information Service, U.S. Department of Commerce, 5285 Port Royal Rd., Springfield, VA 22161 ph: (800) 553-6847 fax: $(703) 605-6900$

email: orders@nits.fedworld.gov

online ordering: http://www.ntis.gov/ordering.htm 


\section{Summary of Uranium Solubility Studies in Concrete Waste Forms and Vadose Zone Environments}

EC Golovich

DM Wellman

RJ Serne

CC Bovaird

September 2011

Prepared for

the U.S. Department of Energy

Under Contract DE-AC05-76RL01830

Pacific Northwest National Laboratory

Richland, Washington 99352 


\section{Executive Summary}

One of the methods being considered for safely disposing of Category 3 low-level radioactive wastes is to encase the waste in concrete. Concrete encasement would contain and isolate the waste packages from the hydrologic environment and act as an intrusion barrier. The current plan for waste isolation consists of stacking low-level waste packages on a trench floor, surrounding the stacks with reinforced steel, and encasing these packages in concrete. These concrete-encased waste stacks are expected to vary in size with maximum dimensions of $6.4 \mathrm{~m}$ long, $2.7 \mathrm{~m}$ wide, and $4 \mathrm{~m}$ high. The waste stacks are expected to have a surrounding minimum thickness of $15 \mathrm{~cm}$ of concrete encasement. These concreteencased waste packages are expected to withstand environmental exposure (solar radiation, temperature variations, and precipitation) until an interim soil cover or permanent closure cover is installed and to remain largely intact thereafter. Any failure of concrete encasement may result in water intrusion and consequent mobilization of radionuclides from the waste packages.

This report presents the results of investigations elucidating the uranium mineral phases controlling the long-term fate of uranium within concrete waste forms and the solubility of these phases in concrete pore waters and alkaline, circum-neutral vadose zone environments. 



\section{Acronyms and Abbreviations}

$\begin{array}{ll}\text { BFS } & \text { blast furnace slag } \\ \text { GWB } & \text { Geochemist Work Bench } \\ \text { HEIS } & \text { Hanford Environmental Information Systems } \\ \text { L } & \text { limestone } \\ \text { OPC } & \text { ordinary Portland cement } \\ \text { SEM } & \text { scanning electron microscope } \\ \text { SEM-EDS } & \text { SEM-energy dispersive spectroscopy } \\ \text { SRPC } & \text { sulfate-resistant Portland cement } \\ \text { TRLIF } & \text { time-resolved laser induced fluorescence } \\ \text { XRD } & \text { X-ray diffraction } \\ \text { XRF } & \text { X-ray fluorescence }\end{array}$





\section{Contents}

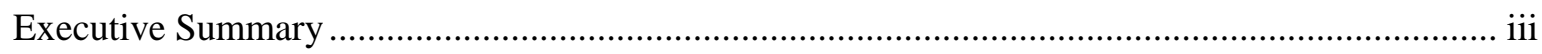

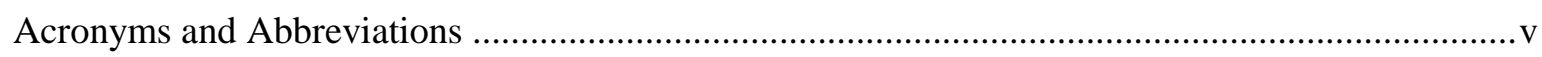

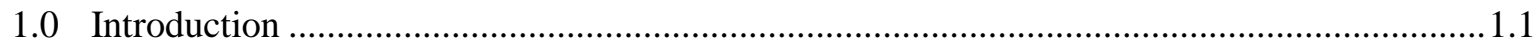

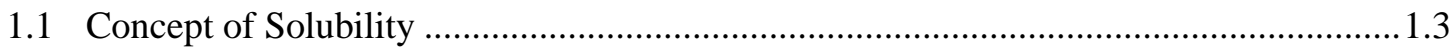

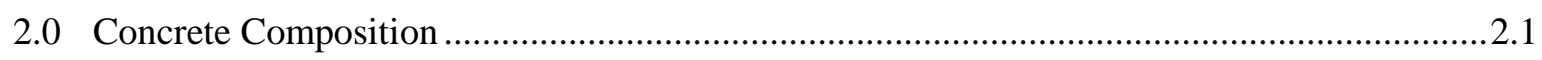

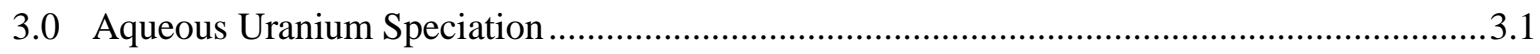

4.0 Solubility of Uranium in Concrete Waste Forms ......................................................... 4.1

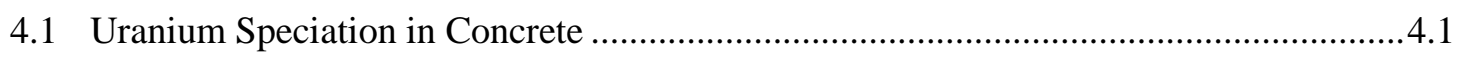

4.2 Uranium Solubility in Ambient Conditions ............................................................ 4.7

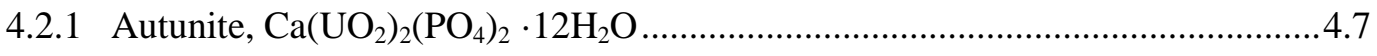

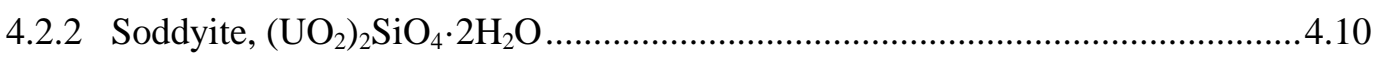

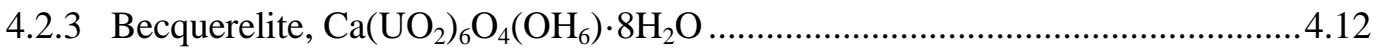

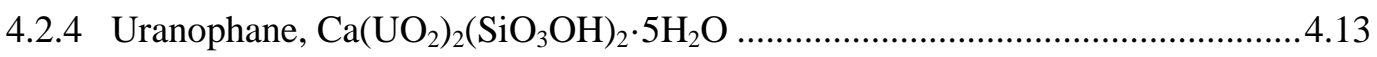

4.3 Uranium Solubility Aqueous and Solid Phase Speciation Modeling ............................4.14

4.4 EXAFS Analysis of Uranium Solubility Solids .........................................................18

5.0 Summary of Uranium Solubility in Vadose Zone Sediment ..............................................5.1

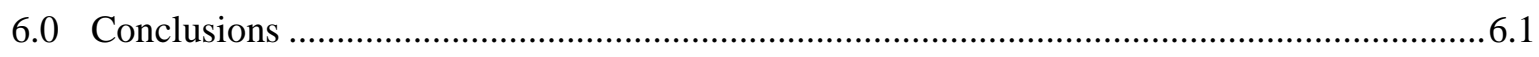

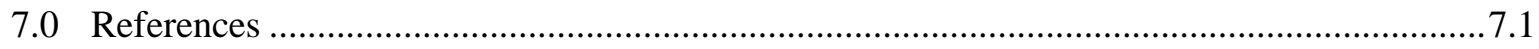

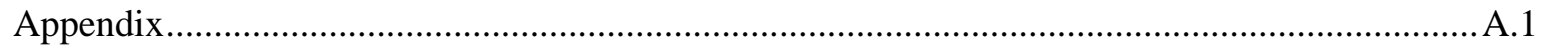




\section{Figures}

3.1 Percent Distribution of $\mathrm{U}^{6+}-\mathrm{H} 2 \mathrm{O}$ System at $25^{\circ} \mathrm{C}, \mathrm{I}=0.1 \mathrm{M}, \mathrm{PCO}_{2}=0$ bar and $\Sigma \mathrm{U}^{6+}=$ $10^{6} \mathrm{M}$ in the Absence of Complexing Ligands Other than Hydroxide.....

3.2 Percent Distribution of $\mathrm{U}^{6+}$ Species Calculated Using MINTEQA2 at $25^{\circ} \mathrm{C}, \mathrm{I}=0.1 \mathrm{M}$, and $\mathrm{pCO}_{2}=10^{-3.5}$ bar for $\sum \mathrm{U}^{6+}=10^{-6} \mathrm{M}$.

3.3 Percent Distribution of $\mathrm{U}^{6+}$ Aqueous Species Calculated Using MINTEQA2 in Hanford Groundwater Well-699-S3-25

4.1 Solubility of Autunite in Simulated Portland Cement-Equilibrated Waters

4.2 Scanning-Electron Photomicrographs of Solids Material from the Reaction of Autunite in OPC/BFS/L Pore Water

4.3 Solubility of Calcium Meta-Autunite as a Function of $\mathrm{pH}$ with Relative Aqueous Phosphate Concentrations of $0.001 \mathrm{M}, 0.01 \mathrm{M}$, and $0.1 \mathrm{M}$

4.4 Solubility of Calcium Meta-Autunite as a Function of Phosphate, 0.001 M, 0.01 M, and $0.1 \mathrm{M}$

4.5 Solubility of Soddyite in Simulated Portland Cement-Equilibrated Waters

4.6 Scanning-Electron Photomicrographs of Solids Material from the Reaction of Soddyite in Harwell Pore Water.

4.7 Scanning-Electron Photomicrographs of Solids Material from the Reaction of Soddyite in OPC/L Pore Water Displaying the Formation of Acicular, Fibrous Coarse-Grained Tuffs

4.8 Solubility of Becquerlite in Simulated Portland Cement-Equilibrated Waters.

4.9 Scanning-Electron Photomicrographs of Solids Material from the Reaction of Becquerlite in Harwell Pore Water Displaying the Formation of Poorly Crystalline, Mixed Sodiumand Calcium-Oxyhydroxide Phase on the Surface of Becquerlite Crystals

4.10 Solubility of Uranophane in Simulated Portland Cement-Equilibrated Waters

4.11 Scanning-Electron Photomicrographs of Solids Material from the Reaction of Uranophane in 9:1 BFS/OPC Pore Water Displaying the Formation of Acicular, Fibrous Fine-Grained Crystal Tuffs

4.12 EXAFS of 3.5 and 1 Year Autunite Mineral Tests Autunite Mineral, Harwell Reacted Autunite After 3.5 Months, Harwell Reacted Autunite After 1 Year, BFS Reacted Autunite After 3.5 Months, and BFS Reacted Autunite After 1 Year

4.13 EXAFS of 3.5 Month Reacted Autunite Mineral Tests Autunite Mineral, SRPC Reacted Autunite After 3.5 Months, Harwell Reacted Autunite After 3.5 Months, and BFS Reacted Autunite After 3.5 Months

4.14 EXAFS of 3.5 Month Reacted Soddyite Mineral Tests Soddyite Mineral, Harwell Reacted Soddyite After 3.5 Months, OPC/L Reacted Soddyite After 3.5 Months, BFS Reacted Soddyite After 3.5 Months, and Uranophane Mineral

4.15 EXAFS of 3.5 Month Reacted Uranophane Mineral Tests Uranophane Mineral, BFS Reacted Uranophane After 3.5 Months, Harwell Reacted Uranophane After 3.5 Months, and OPC/L Reacted Uranophane After 3.5 Months 


\section{Tables}

3.1 Composition of Typical Hanford Groundwater (HGW) from Monitoring Well-699-S3-25 ...... 3.3

4.1 Uraninite Alteration Phases Identified in Wronkiewicz et al. (1997) ........................................ 4.2

4.2 U Steady-State Concentrations for $\mathrm{UO}_{2}$ Pellets in Contact With Various Waters..................... 4.3

4.3 Solubility Product for Soddyite--Literature Values ............................................................. 4.5

4.4 Uranium (VI) Minerals Containing Components Common to Cement ................................... 4.6

4.5 Chemical Composition of Portland Cement-Equilibrated Waters ........................................... 4.7

4.6 Thermodynamic Geochemical Modeling Results for Simulated Concrete Porefluids with Uranium Phases Identified as Primary Controls on Uranium Mobility in

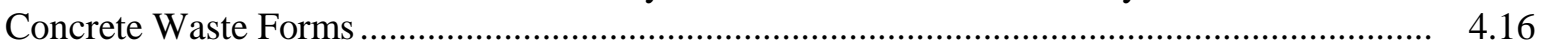

4.7 Aqueous Speciation of GWB Simulation at Final pH ..................................................... 4.17

4.8 Results of Linear Combination Fit of Autunite Mineral Tests................................................ 4.20

4.9 Results of Linear Combination Fit of Soddyite Mineral Tests .............................................. 4.22

4.10 Results of Linear Combination Fit of Uranophane Mineral Tests ......................................... 4.23 


\subsection{Introduction}

One of the methods being considered for safely disposing of Category 3 low-level radioactive wastes is to encase the waste in concrete. Concrete encasement would contain and isolate the waste packages from the hydrologic environment and act as an intrusion barrier. The current plan for waste isolation consists of stacking low-level waste packages on a trench floor, surrounding the stacks with reinforced steel, and encasing these packages in concrete. These concrete-encased waste stacks are expected to vary in size with maximum dimensions of $6.4 \mathrm{~m}$ long, $2.7 \mathrm{~m}$ wide, and $4 \mathrm{~m}$ high. The waste stacks are expected to have a surrounding minimum thickness of $15 \mathrm{~cm}$ of concrete encasement. These concreteencased waste packages are expected to withstand environmental exposure (solar radiation, temperature variations, and precipitation) until an interim soil cover or permanent closure cover is installed and to remain largely intact thereafter. Any failure of concrete encasement may result in water intrusion and consequent mobilization of radionuclides from the waste packages.

Uranium is a significant component and long-term dose contributor in category 3 waste (Wood et al. 1995; Mann et al. 2001). Sorption of uranium to components of cementitous materials has been the subject of several investigations, including the following:

- metal oxides (Plotnikov and Bannykh 1997c, b, a)

- carbonate-rich sediments and minerals (Kaplan et al. 1998; Carroll et al. 1992; Carroll and Bruno 1991 ; Tait et al. 2002; Kelly et al. 2003)

- iron-bearing minerals (Duff et al. 2002 ; Rovira et al. 2000)

- aluminum oxide (Denecke et al. 2003)

- silicon dioxide (Prikryl et al. 2001; Moroni and Glasser 1995)

- cement-specific components such as calcium-silicate-hydrates (Kienzler et al. 2001; Matzen et al. 2000; Altenhein-Hasse et al. 1994) and calcium-oxides (Moroni and Glasser 1995).

Sutton et al. (2003) suggested an apparent two-stage sorption mechanism attributed to surface complexation of uranium with siloxyl groups in grout. Sylwester et al. (1999) supported this hypothesis using X-ray absorption fine structure spectroscopy and X-ray absorption near-edge spectroscopy demonstrating that uranyl interacts with cement components (i.e., $\mathrm{SiO}_{2}$ ) through inner-sphere bonding mechanisms by sharing uranyl, equatorial oxygen atoms with the mineral surface. This is significant in terms of uranium chemistry and retention in concrete waste forms for two reasons. First, in general, inner-sphere sorption complexes, relative to other mechanisms of sorption, are the most stable sorptive complexes and least susceptible to desorption (Sposito 1989). Additionally, sorption occurring via innersphere complexes is believed to be an important precursor step in surface precipitation of uranyl minerals (Sutton et al. 2003). This suggests long-term immobilization of uranium within concrete waste forms may occur through the formation of uranium mineral phases.

The high $\mathrm{pH}$ conditions of grout material, $\mathrm{pH} \sim 12$, limits the solubility of uranium by forming uranyloxides, -hydroxides and uranate salts (Serne et al. 1992a; Serne et al. 1992b; Serne et al. 1995; Serne et al. 1989; Serne et al. 1996a; Serne et al. 1996b; Krupka and Serne 1996; Sutton 1999; Sutton et al. 1999). However, the solubility of uranium in concrete waste forms has generally been investigated from undersaturated, model solutions (Moroni and Glasser 1995; Brownsword et al. 1990 ; Atkins et al. 1988; 
Glasser et al. 1985). Glasser et al. (1986) and Atkins et al. (1988) examined the solubility of uranium in the model $\mathrm{Ca}-\mathrm{UO}_{3}-\mathrm{H}_{2} \mathrm{O}$ system, demonstrating the importance of calcium and sodium uranate phases. Although the results of this investigation provided valuable information regarding the formation of calcium and sodium uranate phases relevant to concrete waste forms, the model system neglects the chemical complexities associated with concrete pore waters given the absence of the dominate component of concrete, $\mathrm{SiO}_{2}$. Brownsword (1990) investigated the solubility of uranium in cement-equilibrated pore waters. Results demonstrated the solubility of uranium under these conditions is equal to or lower than the solubility of sodium and calcium uranates and therefore concluded the solubility-limiting phase corresponded to calcium and/or sodium uranates. However, no additional support or characterization of the solid phases precipitated from cement-equilibrated pore waters was provided to defend this conclusion. Glasser (2001) noted the difficulty of differentiating the solubility limiting phases for uranium in complex matrices such as concrete waste forms. Correlating the solubility of uranium in cement-equilibrated pore waters to calcium and/or sodium uranates without direct evidence is subject to debate within such a complex chemical system. To this end, Moroni and Glasser (1995) investigate the model $\mathrm{CaO}-\mathrm{UO}_{3}-\mathrm{SiO}_{2}-\mathrm{H}_{2} \mathrm{O}$ system and illustrated the significance of uranyl silicate minerals on the retention of uranium within concrete matrices. Moroni and Glasser (1995) noted the solubility of uranium is not solely a function of uranium loading; rather, it is controlled by the nature of uranium-bearing precipitates and within any phase compatibility region, is ideally independent of the amount of each phase.

In efforts to quantify the long-term stability of uranium in concrete waste forms, solubility studies have previously been conducted on proposed uranium mineral phases that have been predicted via geochemical modeling to be the dominant controls on uranium (Sutton 1999; Sutton et al. 1999; Brownsword et al. 1990; Atkins et al. 1988; Glasser et al. 1985; Glasser 2001; Zhao et al. 1999). However, limited experimental conditions (Brownsword et al. 1990) and the presence of multiple uranium phases have complicated experimental solubility results (Brownsword et al. 1990; Glasser et al. 1985; Zhao et al. 1999). This - in conjunction with geochemical predictions rather than experimental determination of uranium phases - hinders the accuracy of predictions regarding the long-term fate or uranium in concrete waste forms (Cooper and Hodgkinson 1987).

Pointeau et al. performed solubility studies on degraded cement mixtures showing that the uptake of uranium increased when comparing the least and most degraded cement pastes. No attempt was made to identify the solid phases observed in these experiments (Pointeau et al. 2004). EXAFS (extended X-ray absorption on spectroscopy) showed synthesis methods had a direct effect on the local coordination environment of U(VI) in a calcium silicate hydrate structure (Harfouche et al. 2006). Tits et al. (2008) found the solubility limits of U(VI) in cementitious pore waters increased with decreasing calcium concentrations. Increasing Si concentrations was shown to increase the solubility limit. In these studies, the solubility of U(VI) was found to be controlled by calcium uranate. The uptake and speciation of $\mathrm{U}(\mathrm{VI})$ in hardened cement paste was investigated using micro-X-ray fluorescence and X-ray absorption spectroscopy. Results showed the U(VI) speciation resembled that of uranophane and was independent of the mechanism (sorption or diffusion). The solubility limit of $U(V I)$ was found to be approximately $6 x$ $10^{-6} \mathrm{M}$ at $\mathrm{pH} 13.3$ (Wieland et al. 2010).

There have also been a number of recent studies researching solubility of uranium minerals, though not in concrete-dominated environments. Ilton et al. looked at the solubility of Na-boltwoodite in sodium carbonate solutions and found that solubility increased with increasing bicarbonate concentration and $\mathrm{pH}$ 
(Ilton et al. 2006). Thermodynamic properties of various uranium minerals were investigated by GormanLewis et al. (2009) including the following:

- metaschoepite

- becquerelite

- compreignatcite

- sodium compreignacite

- clarkeite
- autunite

- uranyl hydrogen phosphate

- uranyl orthophosphate (Gorman-Lewis et al. 2008a; Gorman-Lewis et al. 2008b;

Gorman-Lewis et al. 2009)

Solubility and calorimetric measurements were also made (Gorman-Lewis et al. 2009). Prikryl (2008) examined the dissolution and growth of uranophane in Ca- and Si-rich solutions with both undersaturated and supersaturated conditions at near-neutral pH (Prikryl 2008). A summary of cited solubility measurements is provided in Table A.1 in the appendix.

This report presents the results of investigations elucidating the uranium mineral phases controlling the long-term fate of uranium within concrete waste forms and the solubility of these phases in concrete pore waters and alkaline, circum-neutral vadose zone environments.

\subsection{Concept of Solubility}

The concept of solubility/precipitation is well established from first principles. Solubility constraints are often used in bounding fate and transport analyses to get an estimate of the distribution of a contaminant between the solution phase and solid phase. See the following reports for discussions and examples of why and how solubility is a valuable construct for addressing fate of uranium and other radionuclides (Nitsche 1991; Pennders et al. 1985; Pryke 1985a, b; Rees 1985). Solubility constructs for pure or solid-solution phases give an upper bound on the concentrations that a researcher would expect to observe in a mobile solution phase in equilibrium with solids whereas any coincident adsorptiondesorption reactions should only cause lower amounts of the contaminant to be found in solution.

For simple solubility calculations, researchers must identify the "solubility-controlling" solid and the predominant (or if several aqueous species are present and contribute significantly to the overall solution concentration, researchers needs to know the form and stability of each) aqueous species that forms upon dissolution of the controlling solid. Researchers can then use the thermodynamic solubility product or constant, $\mathrm{K}_{\mathrm{sp}}$, and the stability constant(s), $\mathrm{K}_{\mathrm{i}}$, that describe(s) the formation of the predominant aqueous species to calculate the total solution concentration that should be present in the system of interest. 


\subsection{Concrete Composition}

Concrete is a continuously reacting solid whose component phases continue to change over hundreds of years, albeit very slowly (Taylor 1990; Bogue 1955). The bulk of concrete composition is made of cement, iron blast furnace slag (BFS), fly ash, and water. Additional materials can include steel fibers and various aggregates. Ordinary Portland cement is a finely ground mixture of limestone with other additives balancing out the composition $\left(\mathrm{Al}_{2} \mathrm{O}_{3}, \mathrm{Fe}_{2} \mathrm{O}_{3}, \mathrm{CaO}, \mathrm{MgO} \mathrm{SO}_{3}, \mathrm{~K}_{2} \mathrm{O}\right.$, and $\left.\mathrm{Na}_{2} \mathrm{O}\right)$. In theory, a hydration ratio of only 0.35 is necessary to hydrate all of the cement (Glasser 2001). Although in practice, more water is usually required to create a useable mixture than what is needed to satisfy the hydration demand. The excess water is trapped in pores and becomes strongly alkaline due to two main sources: alkalis in the cement that dissolve in the pore water and aqueous $\mathrm{Ca}(\mathrm{OH})_{2}$. Cement compositions can be tailored in terms of $\mathrm{pH}$, Eh and chemistry to maximize immobilization potential (Atkins and Glasser 1990).

Cements have a high capacity for precipitation. After the radio-species concentration exceeds the threshold value, precipitation will occur. When this occurs, the maximum soluble concentration of the species becomes limited by phase solubility (Glasser 2001). Understanding the phases of uranium found within the concrete waste form is pivotal to predicting long-term uranium mobility. 


\subsection{Aqueous Uranium Speciation}

In concrete and sediment environments, uranium can be found in both solid and liquid phases. Depending on the surrounding conditions, one of two stable valence states [U(IV) and U(VI)] are observed. Under oxidizing conditions, uranium exists as $\mathrm{U}(\mathrm{VI})$ as the uranyl cation $\left(\mathrm{UO}_{2}{ }^{2+}\right)$. Under reducing conditions, uranium transforms to the insoluble $\mathrm{U}(\mathrm{IV})$ state.

Complexation of aqueous uranium can increase the solubility of uranium minerals (Langmuir 1997a, b). Two mechanisms may contribute to the increase in aqueous uranium: 1) a chelating effect, whereby oxygen-containing ligands (i.e., carbonate, phosphate, and hydroxide) bind to uranium in the mineral structure and subsequently release uranium complexes into solution; or 2) release of uranium from the mineral structure is followed by complexation by aqueous ligand. The latter would reduce the activity of uranium in solution allowing further release of uranium from the mineral structure. The composition of the pore waters contains numerous ligands that form stable complexes with uranyl in solution and can significantly increase the aqueous concentration of uranium. Uranyl cations will form strong complexes with hydroxide (Cordfunke 1969, 1964; Grenthe et al. 1992; Langmuir 1997b, 1978); carbonate (Langmuir 1978; Clark et al. 1995); sulfate (Langmuir 1997b, 1978); silicate (Cordfunke 1969, 1964;

Grenthe et al. 1992; Langmuir 1997b, 1978); and phosphate (Sandino and Bruno 1992; Langmuir 1997b, 1978; Grenthe et al. 1992).

System $\mathrm{pH}$ can strongly influence the solubility, hydrolysis, sorption, complexation, and colloid formation of uranium. Hydrolysis reactions are highly sensitive to the activity and concentration of hydrogen ions in solution (Cordfunke 1969; Langmuir 1978; Baes et al. 1953; Sylva and Davidson 1979). For example, Figure 3.1 depicts uranium speciation at $25^{\circ} \mathrm{C}$ in the absence of all ligands except hydroxide, as generated using MINTEQA2 (Allison et al. 1991). The plot shows that stepwise monomeric species dominate the distribution of uranium across the $\mathrm{pH}$ range.

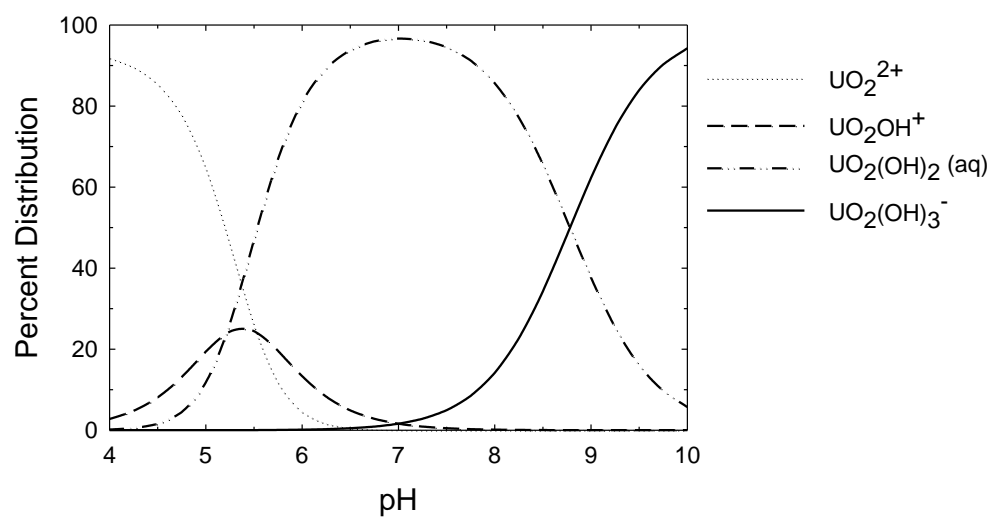

Figure 3.1. Percent Distribution of $\mathrm{U}^{6+}-\mathrm{H} 2 \mathrm{O}$ System at $25^{\circ} \mathrm{C}, \mathrm{I}=0.1 \mathrm{M}, \mathrm{PCO}_{2}=0$ bar and $\Sigma \mathrm{U}^{6+}=10^{6} \mathrm{M}$ in the Absence of Complexing Ligands Other than Hydroxide

Figure 3.2 demonstrates the significance of $\mathrm{pH}$ and ligand identity on the speciation of uranium. The extent to which carbonate competes for uranium over hydroxyl complexes, especially above $\mathrm{pH} 6$, is evident. Uranyl-carbonate species are very significant in the uranium geochemical cycle. They increase 
the solubility of uranium minerals, facilitate uranium (IV) oxidation, and because these species are anionic in nature, they limit the extent of sorption in oxidized waters, thereby increasing the mobility of uranium (Langmuir 1997a, b).

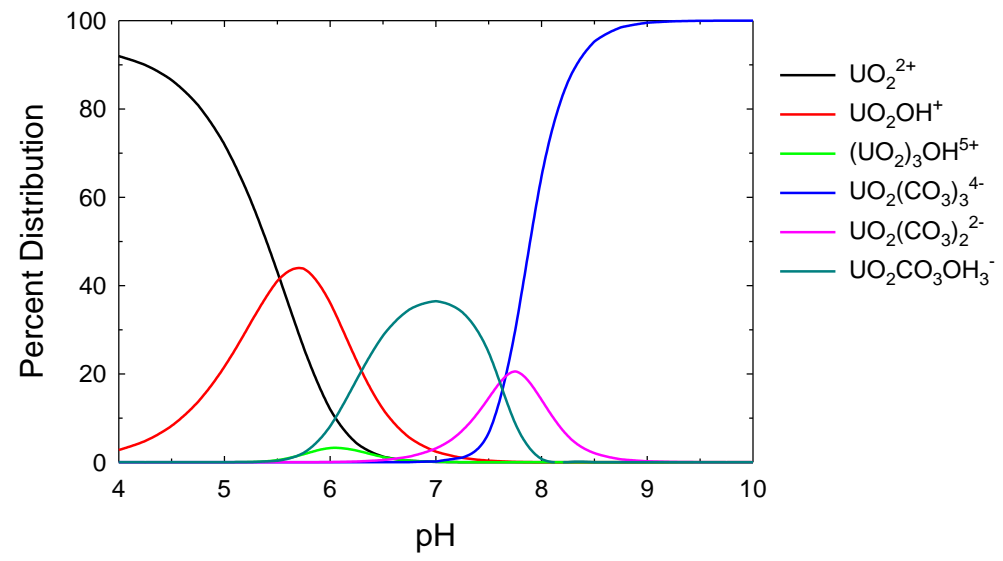

Figure 3.2. Percent Distribution of $U^{6+}$ Species Calculated Using MINTEQA 2 at $25^{\circ} \mathrm{C}, \mathrm{I}=0.1 \mathrm{M}$, and $\mathrm{pCO}_{2}=10^{-3.5}$ bar for $\sum \mathrm{U}^{6+}=10^{-6} \mathrm{M}$

The results shown in Figure 3.3 demonstrate the complexity of the U(VI) speciation in Hanford Site groundwater, and also demonstrate the impact calcium as the $\mathrm{Ca}_{2} \mathrm{UO}_{2} \mathrm{CO}_{3}$ complex can have on the speciation of $\mathrm{U}(\mathrm{VI})$. This complex is expected to be the dominant $\mathrm{U}(\mathrm{VI})$ form under the conditions expected in an alkaline subsurface. Similar to $\mathrm{Ca}^{2+}$, the presence of $\mathrm{Mg}^{2+}$ has been suggested to form a $\mathrm{Mg}_{2} \mathrm{UO}_{2} \mathrm{CO}_{3}$ complex. This complex was not included in the calculations due to a lack of thermodynamic data, but the presence of this complex could have a profound effect on the U(VI) distribution, given the concentration of $\mathrm{Mg}^{2+}$ in Hanford Site groundwater (Table 3.1).

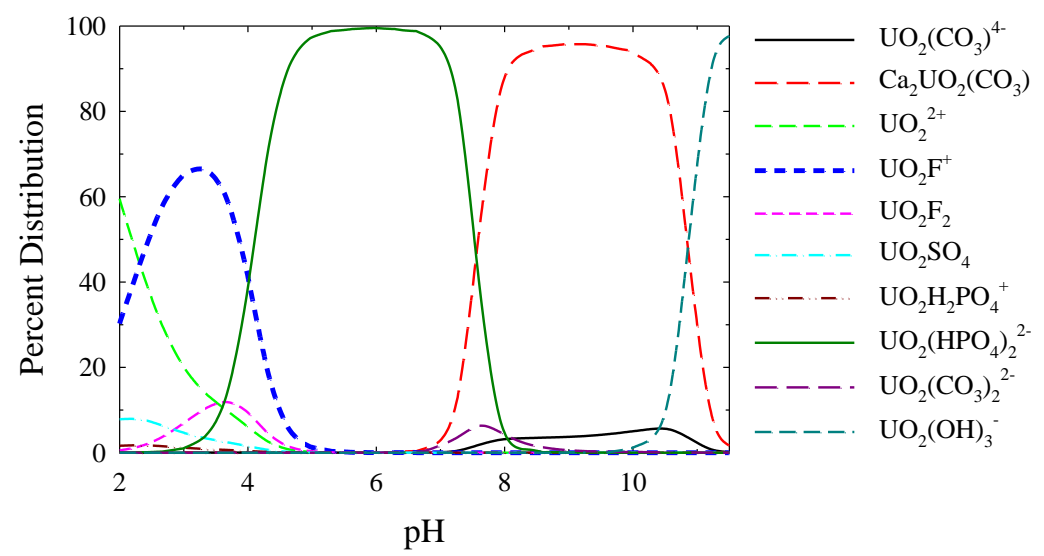

Figure 3.3. Percent Distribution of $\mathrm{U}^{6+}$ Aqueous Species Calculated Using MINTEQA2 in Hanford Site Groundwater Well-699-S3-25

Uranyl-sulfate complexes are important in aqueous environments where $\mathrm{pH}<6$, the evaporation rate is high, sulfides are being oxidized, and carbonate is absent (Ondrus et al. 2003; Garrels and Christ 1965). There are few aqueous uranyl-silicate complexes that are moderately insoluble and readily precipitate to 
form uranyl-silicate minerals. As such, uranyl-silicate minerals are of relatively low solubility and do not rapidly dissolve on exposure to fresh water.

Table 3.1. Composition of Typical Hanford Groundwater (HGW) from Monitoring Well-699-S3-25. Data obtained from (Serne et al. 1995)

\begin{tabular}{|c|c|}
\hline Element & Concentration (mg/L) \\
\hline Alkalinity (as $\mathrm{CaCO}_{3}$ ) & 140.0 \\
\hline $\mathrm{Ba}$ & 0.061 \\
\hline $\mathrm{Br}$ & 0.10 \\
\hline $\mathrm{Ca}$ & 59.0 \\
\hline $\mathrm{CO}_{3}{ }^{2-}$ & 0.80 \\
\hline $\mathrm{Cl}$ & 21.0 \\
\hline Co & 0.0041 \\
\hline $\mathrm{F}$ & 0.60 \\
\hline $\mathrm{Fe}$ & 0.22 \\
\hline $\mathrm{Mg}$ & 15.0 \\
\hline $\mathrm{Mn}$ & 0.09 \\
\hline $\mathrm{NO}_{3}^{-}$ & 1.40 \\
\hline $\mathrm{PO}_{4}{ }^{3-}$ & $<0.34$ \\
\hline $\mathrm{K}$ & 7.70 \\
\hline $\mathrm{Ag}$ & 0.0031 \\
\hline $\mathrm{Na}$ & 26.0 \\
\hline $\mathrm{SO}_{4}^{3-}$ & 110.0 \\
\hline $\mathrm{H}_{4} \mathrm{SiO}_{4}$ & 81.84 \\
\hline $\mathrm{U}$ & 0.01 \\
\hline Specific Conductance $(\mu \mathrm{S} / \mathrm{cm})$ & 557 \\
\hline Temperature $\left({ }^{\circ} \mathrm{C}\right)$ & 19.10 \\
\hline$p H$ & 7.72 \\
\hline$E h(m V)^{(a)}$ & 146.0 \\
\hline Total Hardness as $\mathrm{CaCO}_{3}(\mathrm{mg} / \mathrm{L})$ & 209.48 \\
\hline \multicolumn{2}{|c|}{$\begin{array}{l}\text { (a) Data taken from the Hanford Environmental Information Systems } \\
\text { (HEIS) database using Monitoring Well-699-S6-E14A provides a } \\
\text { general reference for the Hanford Site groundwater redox } \\
\text { conditions. }\end{array}$} \\
\hline
\end{tabular}

In the $\mathrm{pH}$ range of 6-9, phosphate complexes dominant the system when [PO4]/[CO3] $>0.1$. Uranyl forms more stable complexes with phosphate than with any other ligand (Langmuir 1978). For these calculations, the concentration of phosphate is $\sim 1.0 \times 10^{-5} \mathrm{M}$. Under these conditions, aqueous uranyl phosphate phases are minimized due to the hydrolysis and complexation of the uranyl cation with hydroxide and/or carbonate ligands. Sandino and Bruno (1992) noted the difficulty of resolving the solubility of uranium under highly alkaline conditions in the presence of multiple complexing ligands including hydroxide, carbonate, and phosphate (Sandino and Bruno 1992). They surmised the relative stability of phosphate, hydroxide, and carbonate complexes indicated the phosphate complexes dominated even in the presence of strong hydroxyl and carbonato-complexation. However, the formation of mixed 
phases, the exceedingly low solubility of uranyl-phosphate solid phases, and occurrence of phase changes significantly complicates the resolution of solubility data.

Past work (Krupka and Serne 1996; Criscenti et al. 1996) has indicated the solubility-controlling solid is not the common U(VI) oxide, schoepite, that is often used to perform solubility predictions. As shown in work by Serne et al. (1996) and Ewart et al. (1992), it would appear that the uranium solution concentrations in the leachates from cementitious solidified wastes are significantly below values for the solubility of schoepite (Serne et al. 1996b; Ewart et al. 1992). This would also be true for other uraniumbearing solid wastes. Other possible controlling solids that may be present include uranophane, soddyite, calcium uranate, becquerelite, or sodium uranate. 


\subsection{Solubility of Uranium in Concrete Waste Forms}

\subsection{Uranium Speciation in Concrete}

Uranium oxide is a common waste that has been disposed in several U.S. Department of Energy solid waste burial grounds (Wood et al. 1995; Mann et al. 2001; Zachara et al. 2007). The solid $\mathrm{UO}_{2}$ is important as a component in nuclear fuels as well as a primary mineral in important uranium ore deposits. Grambow completed an extensive evaluation of the literature describing the results of dissolution and oxidation studies of spent fuel, $\mathrm{UO}_{2}$, and uraninite (crystalline $\left.\mathrm{UO}_{2}\right)($ Grambow 1989). In general, the sequence of $\mathrm{UO}_{2}$ oxidation products identified in spent fuel and $\mathrm{UO}_{2}$ dissolution studies is shown in Equation (4.1):

$$
\begin{aligned}
\text { reducing conditions } \Rightarrow & \Rightarrow \text { oxidizing conditions } \\
U O_{2} \Rightarrow U_{2+x} & \Rightarrow \Rightarrow U O_{3} \bullet x H_{2} \mathrm{O}
\end{aligned}
$$

The presence of the intermediate oxidation products and the degree of hydration of the uranyl oxide/hydrate depends on temperature and other associated conditions. The review by Grambow contains an extensive bibliography (Grambow 1989). The reader is referred to those references regarding the types and conditions of the experiments that were evaluated by Grambow (1989). In general, once the oxidation reaches the state where $\mathrm{x}$ in Equation (4.1) equals 0.33 (i.e., when the solid becomes $\mathrm{UO}_{2.33}$ ) the dissolution/oxidation rate increases rapidly, especially if the reaction zone on the uraninite surface is a very thin film of water in contact with air.

Erikson et al. conducted characterization and corrosion studies of depleted uranium armor-piercing projectiles (Erikson et al. 1993). Although the geochemical environment associated with these materials is different than those at the Hanford Site, there are similarities in the identified corrosion products of the metallic uranium projectiles. X-ray diffraction (XRD) analysis of a depleted uranium fragments taken from contaminated soil at a target range indicated the presence of a mixture of dehydrated schoepite $\left(\mathrm{UO}_{3} \mathrm{XH}_{2} \mathrm{O}\right)$ and metastudtite $\left(\mathrm{UO}_{4} \cdot 2 \mathrm{H}_{2} \mathrm{O}\right.$, a dehydrated form of studtite). Oxidation products identified in three corrosion experiments of depleted uranium penetrators included a mixture of black and yellow alteration products that contained hyperstoichiometric $\mathrm{U}(\mathrm{IV})$ oxides $\left(\mathrm{UO}_{2+\mathrm{x}}\right)$ (e.g., $\left.\mathrm{UO}_{2.6667} / \alpha \mathrm{U}_{3} \mathrm{O}_{8}\right)$ and schoepite $\left(\mathrm{UO}_{3} \cdot 2 \mathrm{H}_{2} \mathrm{O}\right)$. The formation of metastudtite under these conditions is not understood given that studite usually forms only in highly oxidative environments (such as those formed by hydrogen peroxide or radiolysis products) and these conditions should not be factors in the oxidative corrosion of these uranium penetrators.

The chemistry of the final oxidation products for uranium dioxide is typically more complex when considering aqueous solutions containing dissolved constituents common to soil and groundwater, such as dissolved calcium, silica, and bicarbonate-carbonate. For example, Wronkiewicz et al. and Bates et al. studied the leaching behavior of unirradiated $\mathrm{UO}_{2}$ with a dilute groundwater under unsaturated conditions at $90^{\circ} \mathrm{C}$ (Bates et al. 1990; Wronkiewicz et al. 1991; Wronkiewicz et al. 1992; Wronkiewicz et al. 1996; Wronkiewicz et al. 1997). Phases identified by $\mathrm{XRD}$ on the reacted $\mathrm{UO}_{2}$ surface included schoepite, dehydrated schoepite, compreignacite, uranophane, boltwoodite, sklodowskite, and becquerelite. ${ }^{1}$ In their

\footnotetext{
${ }^{1}$ The formula for becquerelite is often listed different ways by various investigators. The differences are typically in the degree and nature of hydration, such as $\mathrm{CaU}_{6} \mathrm{O}_{19} \cdot 10 \mathrm{H}_{2} \mathrm{O}, \mathrm{CaU}_{6} \mathrm{O}_{19} \cdot 11 \mathrm{H}_{2} \mathrm{O}$, or $\mathrm{Ca}\left(\mathrm{UO}_{2}\right)_{6} \mathrm{O}_{4}(\mathrm{OH})_{6} \cdot 8 \mathrm{H}_{2} \mathrm{O}$.
} 
most recent work, (Wronkiewicz et al. 1997) suggest that the evolution of uranium solids in their oxidation/leaching tests is as shown in Equation (4.2):

$$
\text { Schoepite } \Rightarrow \text { Compreignacite }+ \text { Becquerelite } \Rightarrow \text { Soddyite } \Rightarrow \text { Boltwoodite +Uranophane. }
$$

This progression goes from U(IV) oxide to U(VI) oxide to alkali and alkaline earth U(VI) oxides to $\mathrm{U}(\mathrm{VI})$ silicate to alkali and alkaline earth uranyl silicates and non-uranyl aluminosilicates. Formulas for these minerals are found in Table 4.1.

Ollila also studied the solubility of unirradiated $\mathrm{UO}_{2}$ in several solutions (deionized water, sodium bicarbonate [1 to $10 \mathrm{mmol} / \mathrm{l}$ ], a Swedish groundwater [containing $2.3 \mathrm{mmol} / \mathrm{l} \mathrm{Na}, 0.65 \mathrm{mmol} / \mathrm{l} \mathrm{Ca}$, $2 \mathrm{mmol} / \mathrm{l}$ bicarbonate and $2 \mathrm{mmol} / \mathrm{l} \mathrm{Cl}$ ] and a bentonite saturated water [containing $12 \mathrm{mmol} / \mathrm{l} \mathrm{Na}$, $0.65 \mathrm{mmol} / \mathrm{l} \mathrm{Ca}, 10 \mathrm{mmol} / \mathrm{l}$ bicarbonate and $2.3 \mathrm{mmol} / \mathrm{l} \mathrm{Cl}$ (Ollila 1997). The various batch tests reached a steady-state uranium concentration within 400 to 1000 days. For the tests using deionized water, XRD, and X-ray photoelectron spectroscopy showed the end product was schoepite. The uranium-bearing solid phases present at the end of the other tests did not yield conclusive identification. Computer modeling indicated the phase present in the bentonite-equilibrated solution might be haiweite, a calcium-uranyl silicate with a composition $\left[\mathrm{Ca}\left(\mathrm{UO}_{2}\right)_{2}\left(\mathrm{Si}_{2} \mathrm{O}_{5}\right)_{3} \cdot 5 \mathrm{H}_{2} \mathrm{O}\right]$. The steady state uranium solution concentrations for tests with the four waters are shown in 
Table 4.2. In the comments column, a plausible solubility control based on geochemical modeling is offered based on the closest fit to the observed solution concentrations of uranium.

Table 4.1. Uraninite Alteration Phases Identified in Wronkiewicz et al. (1997)

\begin{tabular}{|c|c|}
\hline \multicolumn{2}{|c|}{ Uranyl-Oxide Hydrates } \\
\hline Schoepite (meta-schoepite) & $\mathrm{UO}_{3} \cdot \mathrm{nH}_{2} \mathrm{O}(\mathrm{n} \# 2)$ \\
\hline Dehydrated Schoepite & $\mathrm{UO}_{3} \cdot(0.8-1.0) \mathrm{H}_{2} \mathrm{O}$ \\
\hline Compreignacite & $(\mathrm{Na}, \mathrm{K})_{2}\left[\left(\mathrm{UO}_{2}\right)_{6} \mathrm{O}_{4}(\mathrm{OH})_{6}\right] \cdot 8 \mathrm{H}_{2} \mathrm{O}$ \\
\hline Becquerlite & $\mathrm{Ca}\left[\left(\mathrm{UO}_{2}\right)_{6} \mathrm{O}_{4}(\mathrm{OH})_{6}\right] \cdot 8 \mathrm{H}_{2} \mathrm{O}$ \\
\hline \multicolumn{2}{|c|}{ Uranyl Silicate Hydrate } \\
\hline Soddyite & $\left(\mathrm{UO}_{2}\right)_{2} \mathrm{SiO}_{4} \cdot 2 \mathrm{H}_{2} \mathrm{O}$ \\
\hline \multicolumn{2}{|c|}{ Uranyl Alkaline Silicate Hydrates } \\
\hline Uranophane & $\mathrm{Ca}\left(\mathrm{UO}_{2}\right) \mathrm{SiO}_{3}(\mathrm{OH})_{2} \cdot 5 \mathrm{H}_{2} \mathrm{O}$ \\
\hline Boltwoodite & $\mathrm{K}_{2}\left(\mathrm{UO}_{2}\right)_{2}\left(\mathrm{SiO}_{4}\right)_{2}\left(\mathrm{H}_{3} \mathrm{O}\right)_{2} \cdot \mathrm{H}_{2} \mathrm{O}$ \\
\hline Na-Boltwoodite & $(\mathrm{Na}, \mathrm{K})\left(\mathrm{UO}_{2}\right)\left(\mathrm{SiO}_{4}\right)\left(\mathrm{H}_{3} \mathrm{O}\right) \cdot \mathrm{H}_{2} \mathrm{O}$ \\
\hline Sklodowskite & $\mathrm{Mg}\left(\mathrm{UO}_{2}\right)_{2}\left(\mathrm{SiO}_{4}\right)_{2}\left(\mathrm{H}_{3} \mathrm{O}\right)_{2} \cdot 2 \mathrm{H}_{2} \mathrm{O}$ \\
\hline \multicolumn{2}{|c|}{ Non-Uranyl Phases } \\
\hline Palygorskite & $\left(\mathrm{Mg}, \mathrm{Al}_{0.12-0.66}\right)_{5}\left(\mathrm{Si}_{,} \mathrm{Al}_{0.12-0.66}\right)_{8} \mathrm{O}_{20}(\mathrm{OH})_{5} \cdot 4 \mathrm{H}_{2} \mathrm{O}$ \\
\hline
\end{tabular}


Table 4.2. U Steady-State Concentrations for $\mathrm{UO}_{2}$ Pellets in Contact With Various Waters

\begin{tabular}{ccc}
\hline Water Type & U Conc. $(\mathrm{M})$ & Comments \\
\hline $\mathrm{NaHCO}_{3}-2 \mathrm{mmol} / \mathrm{l}$ & $6 \times 10^{-5}$ & $\mathrm{U}_{3} \mathrm{O}_{7} / \mathrm{U}_{3} \mathrm{O}_{8}$ redox control \\
Swedish groundwater & 1 to $2 \times 10^{-5}$ & $\mathrm{U}_{3} \mathrm{O}_{7} / \mathrm{U}_{3} \mathrm{O}_{8}$ redox control \\
Deionized water & $6 \times 10^{-6}$ & schoepite @ pO $\mathrm{O}_{2}=0.2$ atm \\
Bentonite equilibrated & $8 \times 10^{-7}$ & Haiweeite \\
\hline
\end{tabular}

Finch and Ewing and Janeczek and Ewing have reviewed the oxidation and dissolution products of the mineral uraninite (crystalline $\mathrm{UO}_{2}$ ) (Finch and Ewing 1990; Finch and Ewing 1992b; Janeczek and Ewing 1992b, a). Their conclusions are based on results from their own mineralogical studies of natural uraninite and uranium ore deposit samples, as well as information gleaned from the literature. The schematic pathway for the dissolution of $\mathrm{UO}_{2}$ in oxidizing aqueous solutions is as follows:

- Initial stage consists of radiolytic surface oxidation of $\mathrm{UO}_{2}$ (Equation 4.3):

$$
\mathrm{UO}_{2}+\frac{x}{2} \mathrm{O}_{2} \rightarrow U O_{2+x}
$$

- Full oxidation follows resulting in the formation of U(VI)-oxide hydrates, which may contain other cations (e.g., calcium and potassium) that are present in the contacting aqueous solution (Equation 4.4):

$$
\begin{gathered}
\mathrm{UO}_{2+x}+\frac{(1-x)}{2} \mathrm{O}_{2}+2 \mathrm{H}_{2} \mathrm{O} \rightarrow \mathrm{UO}_{3} \bullet 2 \mathrm{H}_{2} \mathrm{O} \text { (schoepite) } \\
\mathrm{UO}_{2=x}+\mathrm{O}_{2}+\mathrm{Ca}^{2+}+(16-6 x) \mathrm{H}_{2} \mathrm{O} \rightarrow \underset{\left.\mathrm{O}_{2}\right)_{6} \mathrm{O}_{4}(\mathrm{OH})_{6} \bullet 8 \mathrm{H}_{2} \mathrm{O}}{ } \\
\text { (becquerelite) }
\end{gathered}
$$

- Final alteration may include formation of uranyl silicates or phosphates depending on the presence of these dissolved constituents and their relative proportions (Equation 4.5):

$$
\mathrm{Ca}\left(\mathrm{UO}_{2}\right)_{6} \mathrm{O}_{4}(\mathrm{OH})_{6} \bullet 8 \mathrm{H}_{2} \mathrm{O}+6 \mathrm{SiO}_{2}+2 \mathrm{Ca}^{2+} 9 \mathrm{H}_{2} \mathrm{O} \rightarrow 3 \mathrm{Ca}\left[\left(\mathrm{UO}_{2}\right)\left(\mathrm{SiO}_{3} \mathrm{OH}\right]_{2} \bullet 5 \mathrm{H}_{2} \mathrm{O}+4 \mathrm{H}^{+}\right.
$$

Natural uraninite is not a pure mineral and is always partially oxidized. Although its composition is nominally given as $\mathrm{UO}_{2}$, uraninite is actually nonstoichiometric and has a highly defective structure (Janeczek and Ewing 1992b, a). The nonstoichiometry and defects are caused by oxidation of uranium from +4 to +6 , cationic substitution, and damage from $\alpha$-decay. To reflect this nonstoichiometry and these potential cation substitutions, Janeczek and Ewing have formulated the revised formula $\left[\mathrm{U}^{4+}{ }_{(1-\mathrm{x}-\mathrm{y}-\mathrm{z})} \mathrm{U}^{6+}{ }_{\mathrm{x}} \mathrm{REE}^{3+}{ }_{\mathrm{y}} \mathrm{M}^{2+}{ }_{\mathrm{z}}\right] \mathrm{O}_{(2+\mathrm{x}-0.5 \mathrm{y}-\mathrm{z})}$ for uraninite where $\mathrm{REE}$ are rare earth cations and $\mathrm{M}$ are alkalineearth cations (Janeczek and Ewing 1992b, a). The formula shows the concentrations of excess oxygen required to counteract the increase in positive charge from $\mathrm{U}^{6+}$ is less than that indicated from the amount of $\mathrm{U}^{6+}$ alone. Janeczek and Ewing (1992a, b) suggest the combination of nonstoichiometry and cation substitution may increase the stability field of uraninite under oxidizing conditions relative to synthetic $\mathrm{UO}_{2+\mathrm{x}}$. 
Uraninite remains relatively insoluble as it oxidizes to $\mathrm{UO}_{2.25}$. Oxidation of $\mathrm{UO}_{2}$ beyond $\mathrm{UO}_{2.33}$ (same as $\alpha \mathrm{U}_{3} \mathrm{O}_{7}$ ) in an aqueous environment is rapid and accompanied by hydration to produce the uranyl $[\mathrm{U}(\mathrm{VI})]$ oxide hydrates. Although $\mathrm{U}_{3} \mathrm{O}_{8}$ has not been identified in nature, the sheet structures in uranyl oxide hydrates are similar to the $\mathrm{U}_{3} \mathrm{O}_{8}$ structure (Finch and Ewing 1991). Schoepite is the first uranyl oxide hydrate to form.

In nature, schoepite always coexists with alkali and alkaline earth uranyl oxide hydrates (Finch and Ewing 1991). For example, solubility studies by Sandino and Grambow indicate that uranyl hydroxide transforms essentially spontaneously to becquerelite $\left(\mathrm{CaU}_{6} \mathrm{O}_{19} \cdot 11 \mathrm{H}_{2} \mathrm{O}\right)$ and compreignacite $\left(\mathrm{K}_{2} \mathrm{U}_{6} \mathrm{O}_{19} \cdot 11 \mathrm{H}_{2} \mathrm{O}\right)$ at room temperature after short contact times in solutions containing dissolved calcium and potassium, respectively (Sandino and Grambow 1994). Uranium-series disequilibrium data and microscopic analysis by Finch et al. of natural mineral specimens indicate that becquerelite can remain stable for hundreds of thousands of years or longer in geologic environments. Sodium uranyl hydrates are rare in nature (Finch et al. 1995). The mineral clarkeite $\left[\left(\mathrm{Na}_{2}, \mathrm{Ca}, \mathrm{Pb}\right)_{2} \mathrm{U}_{2}(\mathrm{O}, \mathrm{OH})_{7}\right]$ has only been found at two localities (Finch and Ewing 1992b; Finch and Ewing 1992a). The specimen that they studied was formed by the alteration of uraninite by hydrothermal (i.e., high temperature) alkali solutions. Moreover, although sodium uranyl hydrates such as clarkeite $\left[\left(\mathrm{Na}_{2}, \mathrm{Ca}, \mathrm{Pb}\right)_{2} \mathrm{U}_{2}(\mathrm{O}, \mathrm{OH})_{7}\right]$ are rare in nature, sodium uranates (e.g., $\mathrm{Na}_{2} \mathrm{U}_{2} \mathrm{O}_{7}$ ) have been identified as precipitates in laboratory experiments involving high $\mathrm{pH}$ and high alkali solutions containing dissolved uranium. Phases such as schoepite and becquerelite can then transform into more chemically complex minerals such as uranophane $\left(\mathrm{CaU}_{2} \mathrm{Si}_{2} \mathrm{O}_{11} \cdot 6 \mathrm{H}_{2} \mathrm{O}\right)$ and soddyite $\left(\mathrm{U}_{2} \mathrm{SiO}_{8} \mathrm{~A} 2 \mathrm{H}_{2} \mathrm{O}\right)$ in the presence of dissolved silica, or the autunite series of uranyl phosphate minerals [e.g., $\mathrm{Ca}\left(\mathrm{UO}_{2}\right)_{2}\left(\mathrm{PO}_{4}\right)_{2} \cdot 10 \mathrm{H}_{2} \mathrm{O}$ ] in the presence of dissolved phosphate (Finch and Ewing 1992b; Finch and Ewing 1992a; Sowder et al. 1996).

Phases such as schoepite and becquerelite can in turn transform to more chemically complex minerals such as uranophane $\left(\mathrm{CaU}_{2} \mathrm{Si}_{2} \mathrm{O}_{11} \cdot 6 \mathrm{H}_{2} \mathrm{O}\right)$ and soddyite $\left(\mathrm{U}_{2} \mathrm{SiO}_{8} \cdot 2 \mathrm{H}_{2} \mathrm{O}\right)$ in the presence of dissolved silica, or the autunite series of uranyl phosphate minerals [e.g., $\mathrm{Ca}\left(\mathrm{UO}_{2}\right)_{2}\left(\mathrm{PO}_{4}\right)_{2} \cdot 10 \mathrm{H}_{2} \mathrm{O}$ ] in the presence of dissolved phosphate (Finch and Ewing 1992b; Finch and Ewing 1992a; Sowder et al. 1996). The sequence of alteration reactions depend on the ratio of dissolved silica to phosphate. The results of Sowder et al. indicate that the presence of dissolved silica $\left(10^{-3} \mathrm{M}\right)$ may even impede the transformation of schoepite to becquerelite (Sowder et al. 1996). The general weathering sequence is shown in Equation (4.6):

$$
\mathrm{UO}_{2} \Rightarrow \text { uranyl silicates (e.g. soddyite) } \Rightarrow \text { uranyl alkali silicates (e.g., uranophane). }
$$

Perez et al. performed dissolution tests on soddyite that was prepared from mixing uranyl nitrate and sodium silicate solutions(Perez et al. 1997). After adjusting the $\mathrm{pH}$ to 4.5 and allowing precipitation to occur over 4 days, the precipitate slurry was refluxed at $60^{\circ} \mathrm{C}$ for 6 hours and then hydrothermally heated in a Parr bomb at $110^{\circ} \mathrm{C}$ for 14 days. XRD, scanning electron microscope (SEM), and Fourier Transform Infrared Spectrometry characterization was performed on the uranyl compound before and after dissolution testing to assure that soddyite was the phase present. Leach tests were performed at $25^{\circ} \mathrm{C}$ in stirred batch reactors at a fixed solid to solution ratio of $1 \mathrm{~g}: 400 \mathrm{ml}$ using solution that contained $10^{-3} \mathrm{M}$ sodium silicate, $7 \times 10^{-3} \mathrm{M}$ sodium perchlorate, and variable amounts of sodium bicarbonate $\left(10^{-3}\right.$ to $2 \times$ $\left.10^{-2} \mathrm{M}\right)$. A steady-state solution uranium concentration was observed within 200 hours. Solutions were filtered through $0.2 \mu \mathrm{m}$ membranes and uranium and $\mathrm{pH}$ were measured. By assuming the compound dissolved congruently, the total solution silica concentration was calculated to be that originally present 
(total carbonate) plus that portion dissolved. Using the measured [pH and uranium] and calculated parameters [ $\mathrm{Si}$ and $\mathrm{HCO}_{3}$ ], the geochemical computer code HARPHRQ was used to speciate the solution and correct for ionic strength effects. The dissolution reaction was assumed to be as shown in Equation (4.7):

$$
\left(\mathrm{UO}_{2}\right)_{2} \mathrm{SiO}_{4} \mathrm{X} 2 \mathrm{H}_{2} \mathrm{O}+6 \mathrm{HCO}_{3} \underset{-}{\rightleftarrows} 2 \mathrm{UO}_{2}\left(\mathrm{CO}_{3}\right)_{3}{ }^{4-}+\mathrm{H}_{4} \mathrm{SiO}_{4}+2 \mathrm{H}^{+}+2 \mathrm{H}_{2} \mathrm{O}
$$

The log solubility product for soddyite was then calculated at $3.9 \pm 0.7$ for solutions that had greater than 5 mmole total carbonate present. This value compares to literature values as shown in Table 4.3. Perez et al. argue that the past literature on soddyite solubility was generally obtained at acid conditions with no carbonate present in the system (Perez et al. 1997). The presence of carbonate reduces the possibility of secondary reactions that change the uranium speciation in both the solution and solid.

Table 4.3. Solubility Product for Soddyite--Literature Values

\begin{tabular}{cc}
\hline $\log \mathrm{K}_{\text {so }}$ & Reference \\
\hline $3.9 \pm 0.7$, if $\mathrm{HCO}_{3}>0.005 \mathrm{M}$ & (Perez et al. 1997) \\
5.74 & (Nguyen et al. 1992) \\
$6.03 \pm 0.45$ & (Moll et al. 1996) \\
$3.0 \pm 2.9$ & (Casas et al. 1994) \\
\hline
\end{tabular}

Murphy and Codell reviewed the literature on uranium (IV) oxidation and uranium (VI) solubility in the context of nuclear repository source-term issues (Murphy and Codell 1999). Murphy and Codell (1999) point out that schoepite and perhaps other U(VI) compounds formed when uranium fuel oxidizes and weathers show retrograde solubility. That is, schoepite, uranophane, and other U(VI) solids are more soluble at lower temperatures than at higher temperatures. Further, the solubilities of U(VI) compounds reported in Murphy and Codell (1999) are fraught with uncertainties in the reaction stoichiometries and possibility that several solid phases were present in the tests. Murphy and Codell (1999) continues the discussion on soddyite solubility as addressed by Perez et al. (1997). The results of Nguyen et al. (1992) may have been influenced by excess silicon found in the solid used to determine solubility, and the tests were only performed from the undersaturation direction. Moll et al. (1996) tests likely had $\mathrm{SiO}_{2}(\mathrm{am})$ precipitating in the test prior to soddyite reaching equilibrium. Murphy and Codell (1999) state that uranophane shows even more retrograde solubility than schoepite such that as repositories cool, schoepite and $\mathrm{SiO}_{2}(\mathrm{am})$ are favored over formation of uranophane. Despite the retrograde observations, Murphy and Codell (1999) reviewed the Pena Blanca natural analog studies and concluded that the uranium weathering sequence was as follows (Equation 4.8):

$$
\text { uraninite } \Rightarrow \text { schoepite } \Rightarrow \text { soddyite } \Rightarrow \text { uranophane. }
$$

Finch reviews the solubility products for U(VI) minerals reported in the literature and calculates estimates for some of the observed minerals that have not been studied in laboratory tests (Finch 1997). Finch used the method of Tardy and Garrels that relies on the simple relationship that the Gibbs free energy of formation of a mineral is the sum of the Gibbs free energies of the component oxides needed to create the mineral (Tardy and Garrels 1976). After tabulating the thermodynamic free energies, Finch 
(1997) developed activity-activity diagrams that plot the stability of various U(VI) solids as a function of solution variables. Becquerlite is the most common U(VI) mineral and should be in equilibrium with silica-poor groundwaters that are in equilibrium with atmospheric $\mathrm{CO}_{2}$ and also saturated with calcite. If the groundwaters are rich in dissolved silica, then uranophane is the more stable U(VI) compound that can form.

Wellman et al. provided in-situ identification of uranium-bearing minerals formed within concrete (Wellman et al. 2007). In this work, Portland cement grout specimens were prepared with a U(VI) nitrate spike and the specimens were aged for various time spans ranging from 2 weeks to 1 year. SEM-energy dispersive spectroscopy (SEM-EDS) and XRD were used to identify the uranium-bearing compounds formed in the specimens. These investigations demonstrated the formation of uranium minerals, after only 2 weeks, within concrete waste forms that were under saturated with respect to uranium solid phases and where sorption was believed to be the mechanism of retention. Concrete matrices over saturated with respect to uranium mineral phases exhibited extensive formation of uranium oxyhydroxide phases during the initial 2-week period. The significance of the uranium paragenetic sequence was clearly demonstrated during the subsequent 2-month time frame. Uranyl oxyhydroxide phases were followed by the formation of mixed uranyl-oxyhydroxide/silicates, leading to the formation of uranyl-silicates, then mixed uranylsilicate/phosphate phases and finally uranyl-phosphate phases. In this work (Wellman et al. 2007), uranium phases were identified to be those of soddyite, becquerelite, uranophane, and autunite. This finding is consistent with that of Ewart et al (1992), Serne et al (1996b), Krupka and Serne (1996), and Criscenti et al. (1996) that uranium phases other than schoepite could be the controlling phase. A short list of uranium minerals containing components common to cement are provided in Table 4.4.

Table 4.4. Uranium (VI) Minerals Containing Components Common to Cement

\begin{tabular}{|c|c|}
\hline Minerals & Chemical Formula \\
\hline \multicolumn{2}{|l|}{ Hydrates } \\
\hline Schoepite & $\mathrm{UO}_{3} \cdot 2 \mathrm{H}_{2} \mathrm{O}$ \\
\hline Becquerelite & $\mathrm{Ca}\left(\mathrm{UO}_{2}\right)_{6} \mathrm{O}_{4}(\mathrm{OH})_{6} \cdot 8 \mathrm{H}_{2} \mathrm{O}$ \\
\hline Compreignacite & $\mathrm{K}_{2}\left(\mathrm{UO}_{2}\right)_{6} \mathrm{O}_{4}(\mathrm{OH})_{6} \cdot 8 \mathrm{H}_{2} \mathrm{O}$ \\
\hline Calcium uranate & $\mathrm{CaUO}_{4}, \mathrm{CaU}_{2} \mathrm{O}_{7}$ \\
\hline Sodium uranate & $\mathrm{Na}_{2} \mathrm{UO}_{4}, \mathrm{Na}_{2} \mathrm{U}_{2} \mathrm{O}_{7}, \mathrm{Na}_{6} \mathrm{U}_{7} \mathrm{O}_{24}$, or $\mathrm{Na}_{2} \mathrm{U}_{6} \mathrm{O}_{19} \cdot 11 \mathrm{H}_{2} \mathrm{O}$ \\
\hline \multicolumn{2}{|l|}{ Silicates } \\
\hline Soddyite & $\left(\mathrm{UO}_{2}\right)_{2}\left(\mathrm{SiO}_{4}\right) \cdot 2 \mathrm{H}_{2} \mathrm{O}$ \\
\hline Weeksite & $\mathrm{K}_{2}\left(\mathrm{UO}_{2}\right)\left(\mathrm{Si}_{2} \mathrm{O}_{5}\right)_{3} \cdot 4 \mathrm{H}_{2} \mathrm{O}$ \\
\hline Boltwoodite & $\mathrm{K}\left(\mathrm{H}_{3} \mathrm{O}\right)\left(\mathrm{UO}_{2}\right)\left(\mathrm{SiO}_{4}\right)$ \\
\hline Uranophane & $\mathrm{Ca}\left(\mathrm{UO}_{2}\right)_{2}\left(\mathrm{SiO}_{3} \mathrm{OH}\right)_{2} \cdot 5 \mathrm{H}_{2} \mathrm{O}$ \\
\hline Haiweeite & $\mathrm{CaO} \cdot 2 \mathrm{UO}_{3} \cdot 6 \mathrm{SiO}_{2} \cdot 5 \mathrm{H}_{2} \mathrm{O}$ \\
\hline Kasolite & $\mathrm{Pb}\left(\mathrm{UO}_{2}\right)\left(\mathrm{SiO}_{4}\right) \cdot \mathrm{H}_{2} \mathrm{O}$ \\
\hline Sklodowskite & $\mathrm{Mg}\left(\mathrm{H}_{3} \mathrm{O}\right)_{2}\left(\mathrm{UO}_{2}\right)\left(\mathrm{SiO}_{4}\right)_{2} \cdot 4 \mathrm{H}_{2} \mathrm{O}$ \\
\hline \multicolumn{2}{|l|}{ Phosphates } \\
\hline Autunite & $\mathrm{Ca}\left(\mathrm{UO}_{2}\right)_{2}\left(\mathrm{PO}_{4}\right)_{2} \cdot 12 \mathrm{H}_{2} \mathrm{O}$ \\
\hline \multicolumn{2}{|l|}{ Carbonates } \\
\hline Andersonite & $\mathrm{Na}_{2} \mathrm{CaUO}_{2}\left(\mathrm{CO}_{3}\right)_{3} \cdot 6 \mathrm{H}_{2} \mathrm{O}$ \\
\hline Grimselite & $\mathrm{K}_{3} \mathrm{Na}\left(\mathrm{UO}_{2}\right)\left(\mathrm{CO}_{3}\right) \cdot \mathrm{H}_{2} \mathrm{O}$ \\
\hline
\end{tabular}




\subsection{Uranium Solubility in Ambient Conditions}

Investigations of uranium solubility have been dominated by work done in inert environments to eliminate the effect of ambient concentrations of oxygen and carbon dioxide. This type of environment is not an effective representation of a real-world scenario. What follows is a summary of the work done by Wellman et al. (2008) to examine uranium solubility in simulate concrete pore water under ambient conditions (Mattigod et al. 2009; Wellman et al. 2008; Wellman et al. 2007).

Previous studies by Wellman et al. (2007) identified autunite, soddyite, becquerelite, and uranophane as major uranium phases in aged Portland cement grout specimens. The solubility of these minerals was measured in simulated concrete pore water by (Wellman et al. 2008) under ambient conditions over a period of 405 days. The pore water compositions were based on measurements by Ewart et al. (1992) of the elemental compositions of pore waters equilibrated with a series of Portland cement compositions: sulfate-resistant Portland cement (SRPC)/limestone (L), ordinary Portland cement (OPC)/BFS/L, BFS/OPC, OPC/L, and Harwell (Ewart et al. 1992). Chemical compositions can be found in Table 4.5.

Table 4.5. Chemical Composition of Portland Cement-Equilibrated Waters (from Ewart et al. 1992)

\begin{tabular}{lccccccccc}
\hline \multicolumn{1}{c}{ Cement } & $\mathrm{Ca}$ & $\mathrm{Na}$ & $\mathrm{Mg}$ & $\mathrm{Cl}$ & $\mathrm{SO}_{4}{ }^{2-}$ & $\mathrm{CO}_{3}{ }^{2-}$ & $\mathrm{Al}$ & $\mathrm{Si}$ & $\mathrm{pH}$ \\
\hline SRPC/L & $6.7 \mathrm{E}-3$ & $2 \mathrm{E}-4$ & $<8 \mathrm{E}-8$ & $4 \mathrm{E}-5$ & $4 \mathrm{E}-5$ & $8.5 \mathrm{E}-5$ & $7.4 \mathrm{E}-4$ & $5.3 \mathrm{E}-6$ & 12.5 \\
$9: 1 \mathrm{BFS} / \mathrm{OPC}$ & $6.8 \mathrm{E}-3$ & $3.4 \mathrm{E}-3$ & $4.7 \mathrm{E}-7$ & $6.2 \mathrm{E}-5$ & & $1 \mathrm{E}-4$ & $8 \mathrm{E}-5$ & $2.3 \mathrm{E}-5$ & 12.2 \\
OPC/BFS/L & $6.7 \mathrm{E}-3$ & $5 \mathrm{E}-3$ & $<8 \mathrm{E}-7$ & $2.4 \mathrm{E}-3$ & $6 \mathrm{E}-3$ & $2.8 \mathrm{E}-4$ & $9.5 \mathrm{E}-5$ & $7 \mathrm{E}-4$ & 12.1 \\
OPC/L & $2 \mathrm{E}-2$ & $8.3 \mathrm{E}-4$ & $<4 \mathrm{E}-8$ & $9 \mathrm{E}-5$ & $1 \mathrm{E}-5$ & $2 \mathrm{E}-5$ & $1 \mathrm{E}-5$ & & 12 \\
Harwell & $1 \mathrm{E}-2$ & $5 \mathrm{E}-5$ & $5 \mathrm{E}-6$ & $2 \mathrm{E}-3$ & $3 \mathrm{E}-3$ & $3 \mathrm{E}-5$ & & & 12 \\
\hline
\end{tabular}

\subsubsection{Autunite, $\mathrm{Ca}\left(\mathrm{UO}_{2}\right)_{2}\left(\mathrm{PO}_{4}\right)_{2} \cdot 12 \mathrm{H}_{2} \mathrm{O}$}

The aqueous concentrations of uranium obtained for autunite in the simulated Portland cementequilibrated pore waters are represented in Figure 4.1 in the form of $\log _{10}[\mathrm{U}(\mathrm{VI})]_{\mathrm{aq}}$ (molality) versus time. The aqueous concentration of uranium reached steady-state within 403 days in the 9:1 BFS/OPS, OPS/BFS/L, and Harwell simulated pore waters. The aqueous concentration of uranium in the OPC/L pore waters deviated widely throughout the first 100 days, but attained a steady concentration between 100 and 403 days. The SRPC/L pore water deviated widely throughout the 400 days of testing. Test periods longer than those presented in this report are necessary to reach steady-state for autunite in SRPC/L pore waters. The aqueous, equilibrium uranium concentration increases in the respective pore waters in the following order: Harwell $<$ OPC/BFS/L < 9:1 BFS/OPC. The increase in aqueous uranium concentrations is correlated with the decrease in the concentration of calcium in the simulated pore water. There was no clear correlation with any other aqueous ligands. 


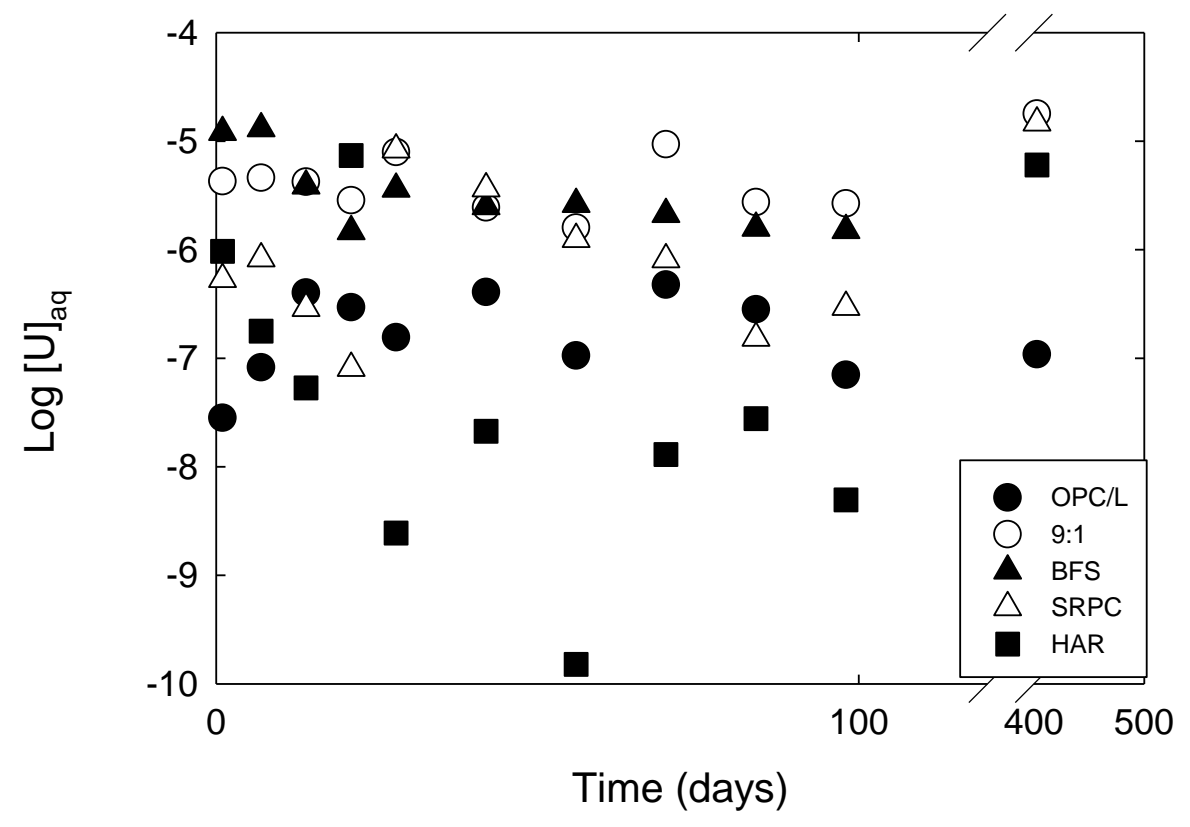

Figure 4.1. Solubility of Autunite in Simulated Portland Cement-Equilibrated Waters

The SEM analyses do not indicate the formation of secondary phases in 9:1 BFS/OPC, OPC/L, Harwell, or SRPC/L pore waters. The formation of secondary phases was observed in the OPC/BFS/L pore water (Figure 4.2). Analysis using EDS indicates the spherical phase is a mixed sodium-calciumbearing uranium-phosphate containing $1.22 \mathrm{wt} \% \mathrm{Na}, 16.57 \mathrm{wt} \% \mathrm{Ca}, 10.10 \mathrm{wt} \% \mathrm{P}, 16.15 \mathrm{wt} \% \mathrm{U}$, and $55.97 \mathrm{wt} \% \mathrm{O}$. The rod-like phase is a mixed sodium-calcium-bearing uranium-phosphate containing $1.31 \mathrm{wt} \% \mathrm{Na}, 14.34 \mathrm{wt} \% \mathrm{Ca}, 8.30 \mathrm{wt} \% \mathrm{P}, 28.02 \mathrm{wt} \% \mathrm{U}$, and $46.26 \mathrm{wt} \% \mathrm{O}$.

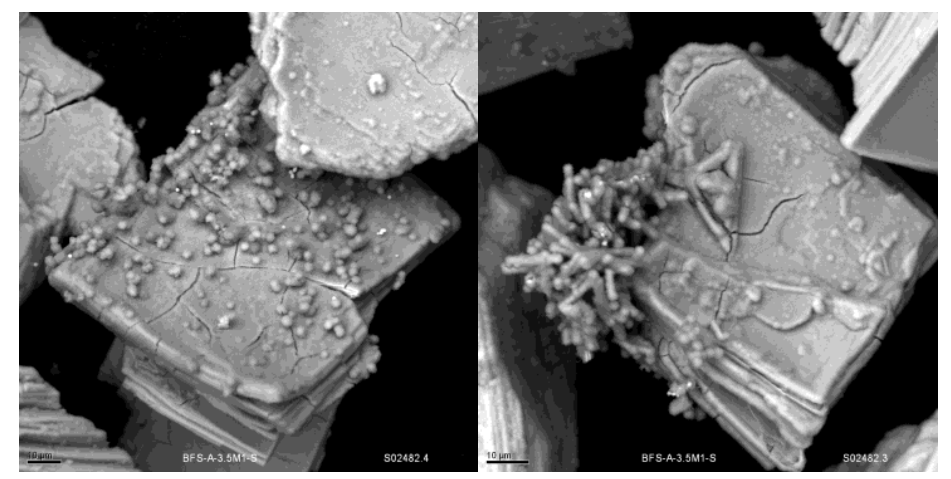

Figure 4.2. Scanning-Electron Photomicrographs of Solids Material from the Reaction of Autunite in $\mathrm{OPC} / \mathrm{BFS} / \mathrm{L}$ Pore water. Photo on the left displays the formation of spherical secondary precipitates; photo on the right indicates the formation of a rod-like secondary phase. 
Figure 4.3 displays the solubility of calcium meta-autunite under the $\mathrm{pH}$ range of 8 to 13 in the presence of $0.001,0.01$, and $0.1 \mathrm{M}$ aqueous phosphate, respectively. Given an aqueous phosphate concentration of $0.001 \mathrm{M}$, the apparent solubility of calcium meta-autunite appears invariant under the $\mathrm{pH}$ range of 8 to 10 . However, at $\mathrm{pH} 11$, the solubility of calcium meta-autunite decreases by an order of magnitude. At $\mathrm{pH}$ values of 12 and 13, the solubility is equal to that measured under the $\mathrm{pH}$ range of 8 to 10. Increasing the aqueous phosphate concentration to $0.01 \mathrm{M}$ increases the apparent solubility by $5 \mathrm{x}$ over the $\mathrm{pH}$ range of 8 to 10 . Consistent with results in $0.001 \mathrm{M}$ phosphate, within analytical error the solubility of calcium meta-autunite is invariant within the $\mathrm{pH}$ range of 8 to 10 . As observed in the presence of $0.001 \mathrm{M}$ phosphate, the apparent solubility of calcium meta-autunite decreases by an order of magnitude at $\mathrm{pH} 11$. However, in contrast to the apparent solubility in $0.001 \mathrm{M}$ phosphate, at $\mathrm{pH} 12-13$ the solubility is not equal to that measured over the $\mathrm{pH}$ range of 8 to 10. Rather, within analytical error, there is no measurable difference in the solubility of calcium meta-autunite over the $\mathrm{pH}$ range of 11 to 13. Additionally, the apparent solubility at $12-13$ is equal to that measured in $0.001 \mathrm{M}$ phosphate. This indicates the apparent solubility of uranium may be influenced by the formation of secondary uraniumphosphate phases. In the presence of $0.1 \mathrm{M}$ phosphate, the apparent solubility of calcium meta-autunite is invariant over the $\mathrm{pH}$ range of 8 to 11 . In contrast to solubility measurements conducted in the presence of $0.001 \mathrm{M}$ and $0.01 \mathrm{M}$ phosphate, there is no decrease in the apparent solubility at $\mathrm{pH} 11$. However, the apparent solubility decreases by 5 times at $\mathrm{pH} 12$ and 10x at $\mathrm{pH} 13$. Moreover, the measured solubility at $\mathrm{pH} 13$ is equal to that measured in $0.001 \mathrm{M}$ and $0.01 \mathrm{M}$ phosphate. This suggests that under highly alkaline conditions, the solubility of uranium is controlled by precipitation of a secondary uranium phase that is invariant with respect to the concentration of aqueous phosphate.

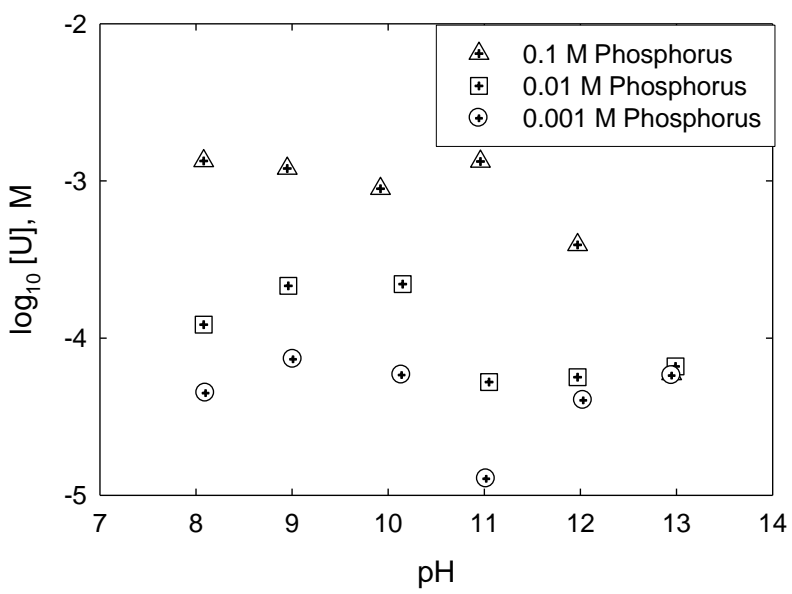

Figure 4.3. Solubility of Calcium Meta-Autunite as a Function of $\mathrm{pH}$ with Relative Aqueous Phosphate Concentrations of $0.001 \mathrm{M}, 0.01 \mathrm{M}$, and $0.1 \mathrm{M}$

The solubility of calcium meta-autunite increases linearly as a function of phosphate, $0.001 \mathrm{M}$, $0.01 \mathrm{M}$, and $0.1 \mathrm{M}$, over the $\mathrm{pH}$ range of 8-12 (Figure 4.4). However, at $\mathrm{pH} 13$ the concentration of uranium is invariant with respect to phosphate concentration. This suggests secondary uranium phases may rapidly precipitate influencing the aqueous concentration of uranium. 


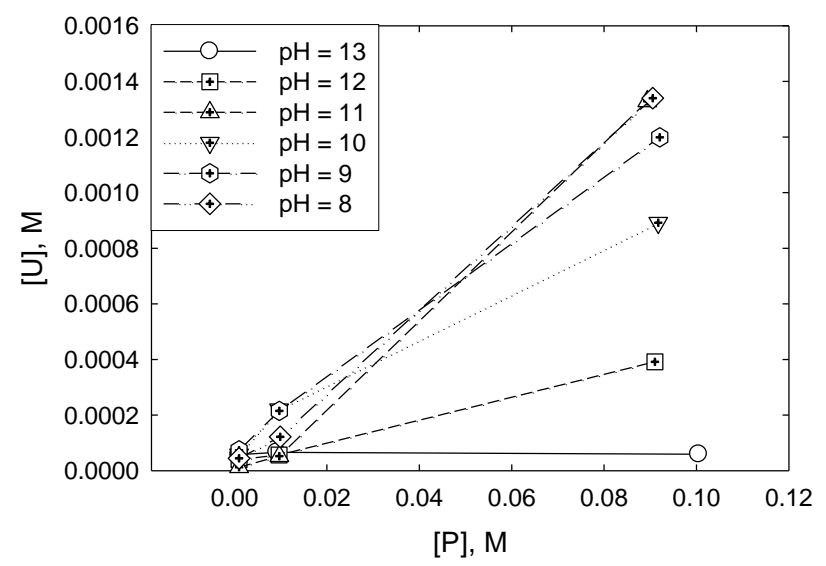

Figure 4.4. Solubility of Calcium Meta-Autunite as a Function of Phosphate, $0.001 \mathrm{M}, 0.01 \mathrm{M}$, and $0.1 \mathrm{M}$

\subsubsection{Soddyite, $\left(\mathrm{UO}_{2}\right)_{2} \mathrm{SiO}_{4} \cdot 2 \mathrm{H}_{2} \mathrm{O}$}

The aqueous concentrations of uranium obtained for soddyite in the simulated Portland cementequilibrated pore waters are represented in Figure 4.5 in the form or $\log _{10}[\mathrm{U}(\mathrm{VI})]_{\mathrm{aq}}$ (molality) versus time. The aqueous concentration of uranium reached steady-state within 403 days in all simulated pore waters, except Harwell. The aqueous concentration of uranium in the Harwell solution appeared to reach steady-state at $\sim 10$ days. However, at 70 days the aqueous concentration of uranium began to increase again. This increase in concentration is seen as far as 403 days. Test periods longer than those presented here are necessary to reach steady-state for soddyite in Harwell pore waters. Moreover, the rate at which equilibrium is reached in the other pore waters differs depending on the pore water composition. Equilibrium is rapidly attained within $\leq 50$ days for soddyite in BFS and 9:1 BFS/OPC. Longer time frames, such as 60 to 100 days, are required to reach equilibrium in SRPC/L and OPC/L pore waters. The aqueous, equilibrium uranium concentration increases in the respective pore waters in the following order: of Harwell $<$ OPC/L < OPC/BFS/L < 9:1 BFS/OPC $=$ SPRC/L. Comparable to aqueous uranium concentrations measured from solubility tests conducted with autunite, the increase in aqueous uranium concentrations is correlated with decreasing concentration of calcium in the simulated pore water. Moreover, the increase in aqueous uranium concentration in OPC/BFS/L, 9:1 BFS/OPC, SPRC/L exhibits a relationship with increasing concentration of aqueous silicon.

The SEM of soddyite in BFS and 9:1 BFS/OPC at 100 days does not reveal the formation of any secondary phases. XRD results confirming that there was no change in mineralogy during solubility testing is pending. The SEM analysis of soddyite in Harwell pore waters reveals a morphologically different phase is present as a minor component of the solid phase (Figure 4.6). Analysis using EDS indicates the phase is a calcium-bearing uranium-silicate containing 1.43-2.01 wt\% Ca, 4.55-5.62 wt\% $\mathrm{Si}, 47.83-62.99 \mathrm{wt} \% \mathrm{U}$, and 29.40-44.04 wt\% O. The morphology is suggestive of uranophane; however, the chemical composition is not strictly consistent with any one calcium-uranium-silicate phase. The formation of a minor inclusion of acicular, fibrous fine-grained crystal tuffs, comparable to the results in Harwell, were also observed in OPC/BFS/L, 9:1 BFS/OPC, SRPC/L pore waters; no additional secondary phases were observed. 
Soddyite in all waters

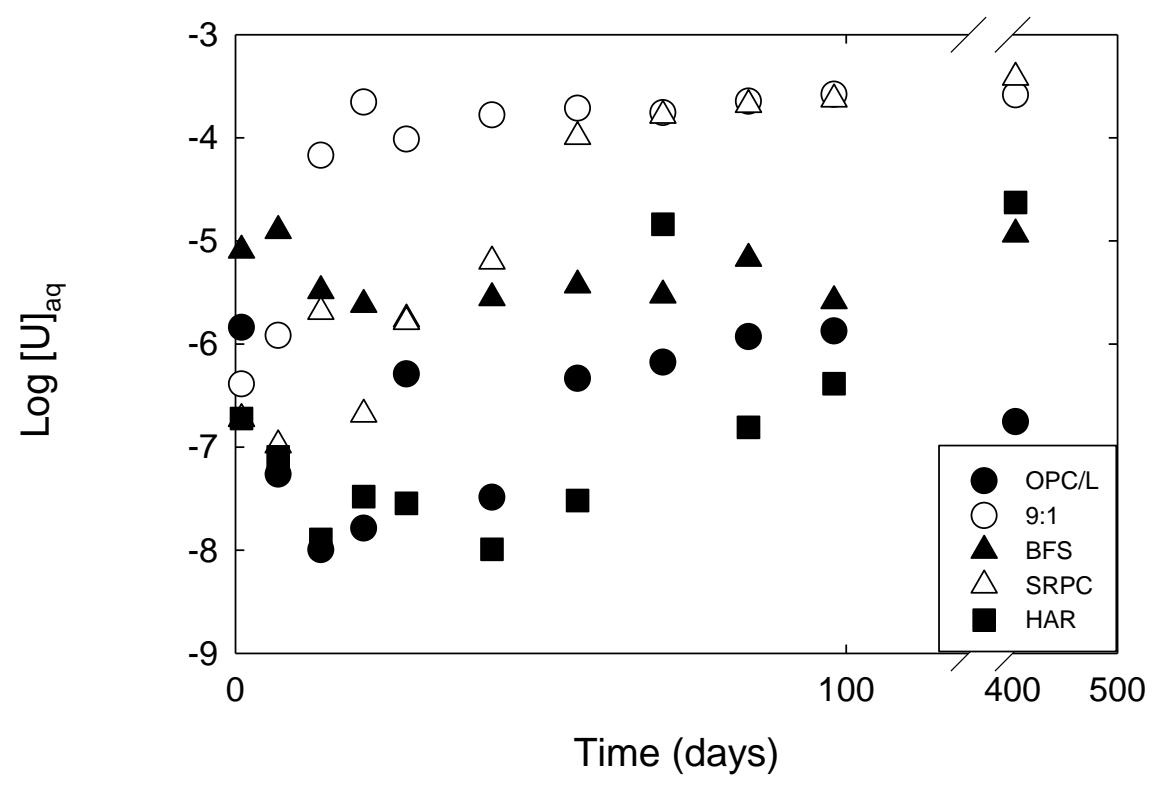

Figure 4.5. Solubility of Soddyite in Simulated Portland Cement-Equilibrated Waters

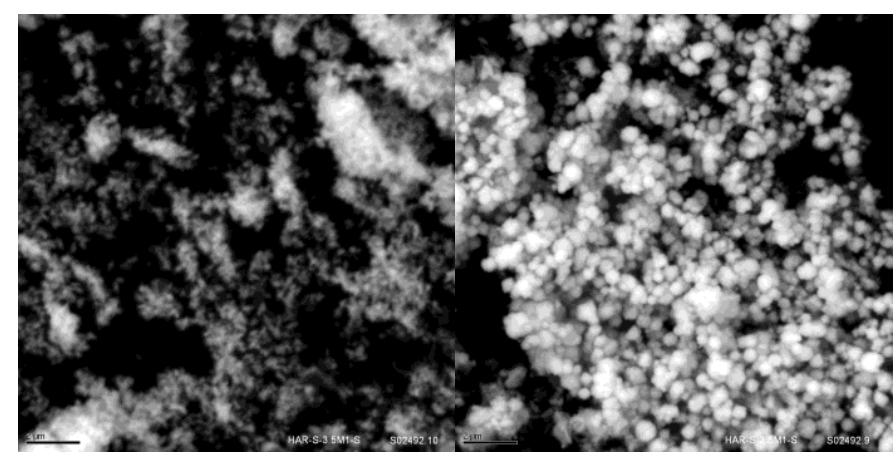

Figure 4.6. Scanning-Electron Photomicrographs of Solids Material from the Reaction of Soddyite in Harwell Pore water. The image on the right shows the persistence of soddyite; the image on the left displays the formation of acicular, fibrous fine-grained crystal tuffs.

Similar results were observed from SEM images of reacted solid phases extracted from the reaction of soddyite in OPC/L. However, the higher concentration of calcium present in OPC/L relative to the Harwell solution resulted in substantial formation of calcium-bearing, fibrous fine-grained tuffs; additionally, the formation acicular, fibrous coarse-grained crystal tuffs also was observed (Figure 4.7). EDS analysis indicates the phase is a sodium-bearing uranium-silicate containing $3.27 \mathrm{wt} \% \mathrm{Na}, 6.29 \mathrm{wt} \%$ $\mathrm{Si}, 51.33 \mathrm{wt} \% \mathrm{U}$, and $39.11 \mathrm{wt} \% \mathrm{O}$. The morphology is consistent with sodium-boltwoodite, an uranophane-group mineral. 


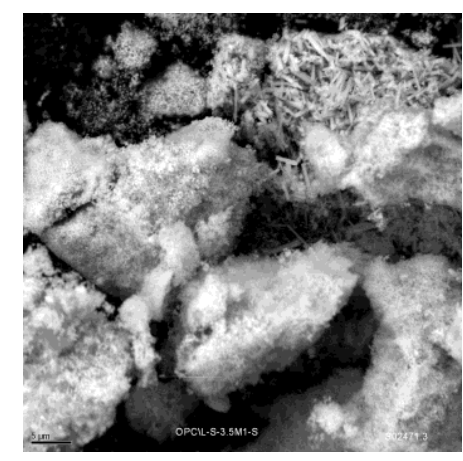

Figure 4.7. Scanning-Electron Photomicrographs of Solids Material from the Reaction of Soddyite in OPC/L Pore water Displaying the Formation of Acicular, Fibrous Coarse-Grained Tuffs

\subsubsection{Becquerelite, $\mathrm{Ca}\left(\mathrm{UO}_{2}\right)_{6} \mathrm{O}_{4}\left(\mathrm{OH}_{6}\right) \cdot 8 \mathrm{H}_{2} \mathrm{O}$}

The aqueous concentration of uranium obtained for becquerlite in the simulated Portland cement-equilibrated pore waters are represented in Figure 4.8 in the form of $\log 10$ [U(VI)]aq (molality) versus time. The aqueous concentrations of uranium reached steady-state within 403 days in the $\mathrm{OPC} / \mathrm{BFS} / \mathrm{L}$ and Harwell simulated pore waters. The aqueous concentration in the OPC/L pore water appeared to attain steady state through 100 days; however, between 83 days and 403 days, the concentration of uranium increased from $3.1 \times 10-9$ moles and $1.75 \times 10-7 \mathrm{M}$. The aqueous concentration of uranium in the 9:1 BFS/OPC pore water deviated widely throughout the duration of testing, increasing to $1 \times 10-4 \mathrm{M}$ after 403 days. The SRPC/L pore water appeared to reach steady state after 21 days; however, the 403-day test had a highly elevated concentration of uranium at $1 \times 10-4 \mathrm{M}$ from $8.8 \times 10-8 \mathrm{M}$. Test periods longer than those presented here are necessary to reach steady state for becquerlite in 9:1 BFS/OPC, SRPC/L and OPC/L pore waters.

Becquerelite in all waters

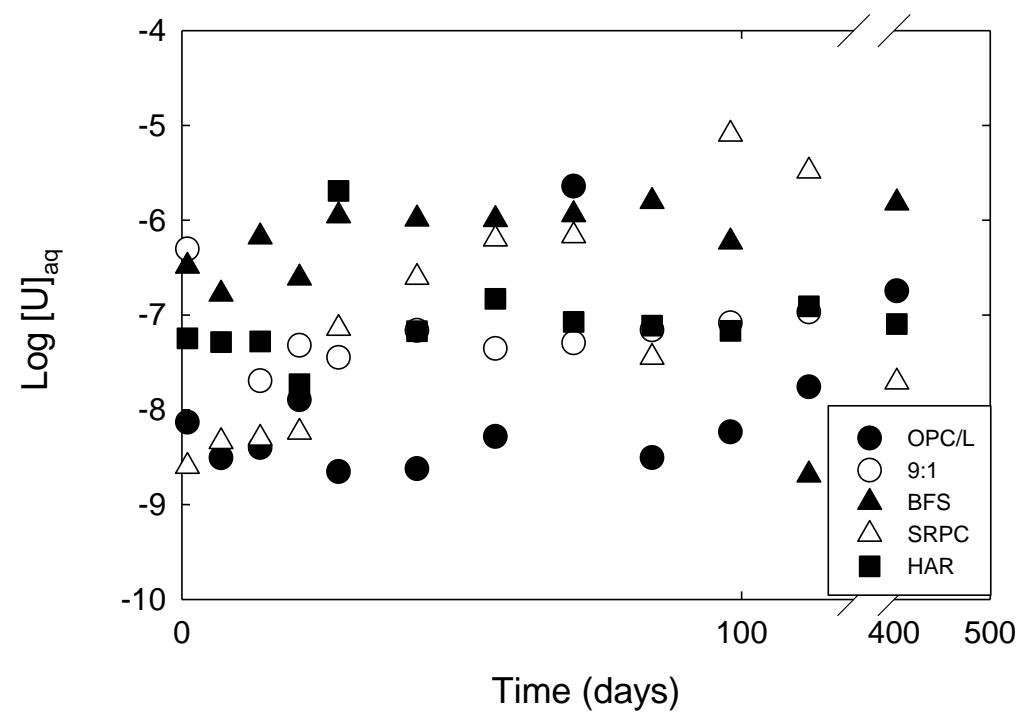

Figure 4.8. Solubility of Becquerlite in Simulated Portland Cement-Equilibrated Waters 
The SEM analyses do not indicate the formation of secondary phases in 9:1 BFS/OPC, OPC/L, $\mathrm{OPC} / \mathrm{BFS} / \mathrm{L}$, or SRPC/L pore waters. In the Harwell pore water, however, the formation of a secondary precipitate that did not possess a well-defined morphology was observed on the surface of some becquerelite crystals (Figure 4.9). The EDS analyses indicated this was a mixed calcium-sodium-uranium phase that was composed of $1.45 \mathrm{wt} \%$ sodium, $2.66 \mathrm{wt} \%$ calcium, and 54.99-92.36 wt\% uranium. This phase is poorly crystalline mixed sodium- and calcium- oxyhydroxide.

Results presented here indicate becquerlite attains equilibrium conditions rapidly within concrete pore waters. There was no observed effect of carbonate or sulfate within the pore waters on the stability of becquerlite, or the formation of secondary phases. The becquerelite will persist within concrete waste forms as a long-term control on uranium.

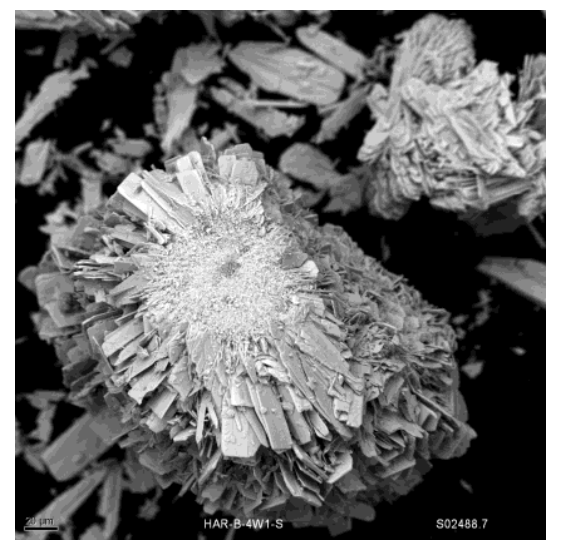

Figure 4.9. Scanning-Electron Photomicrographs of Solids Material from the Reaction of Becquerlite in Harwell Pore water Displaying the Formation of Poorly Crystalline, Mixed Sodium- and Calcium-Oxyhydroxide Phase on the Surface of Becquerlite Crystals

\subsubsection{Uranophane, $\mathrm{Ca}\left(\mathrm{UO}_{2}\right)_{2}\left(\mathrm{SiO}_{3} \mathrm{OH}\right)_{2} \cdot 5 \mathrm{H}_{2} \mathrm{O}$}

The aqueous concentrations of uranium obtained for uranophane in the simulated Portland cementequilibrated pore waters are represented in Figure 4.10 in the form of $\log _{10}[\mathrm{U}(\mathrm{VI})]_{\mathrm{aq}}$ (molality) versus time. The aqueous concentration of uranium reached steady-state within 403 days in all simulated pore waters. Additionally, the rate at which equilibrium was reached is relatively consistent and does not depend on the pore water composition. Equilibrium is rapidly attained within $\leq 30$ days. The aqueous, equilibrium uranium concentration increases in the respective pore waters in the following order: Harwell $\approx \mathrm{OPC} / \mathrm{L}<9: 1 \mathrm{BFS} / \mathrm{OPC}<\mathrm{SPRC} / \mathrm{L}<\mathrm{OPC} / \mathrm{BFS} / \mathrm{L}$. As observed with autunite, becquerelite, and soddyite, the increase in aqueous uranium concentrations is correlated with decreasing concentration of calcium in the simulated pore water. There was no clear correlation with any other aqueous ligands.

No secondary phases were identified in any of the other pore waters. The morphology of all reacted solid phases was the acicular, fibrous fine-grained tuffs consistent with the unreacted uranophane (Figure 4.11). Further, the lack of secondary phases supports the possibility that the acicular, fibrous finegrained tuff phase present in the soddyite post-reaction solids (discussed above) is an uranophane group phase. 


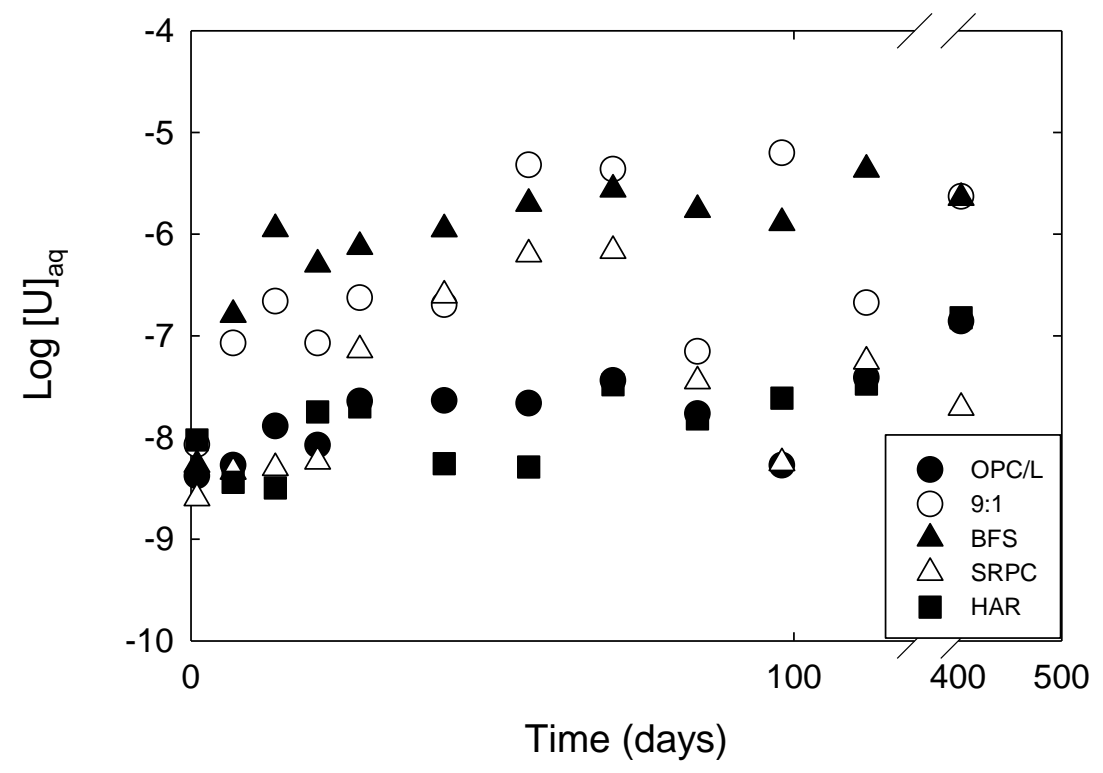

Figure 4.10. Solubility of Uranophane in Simulated Portland Cement-Equilibrated Waters

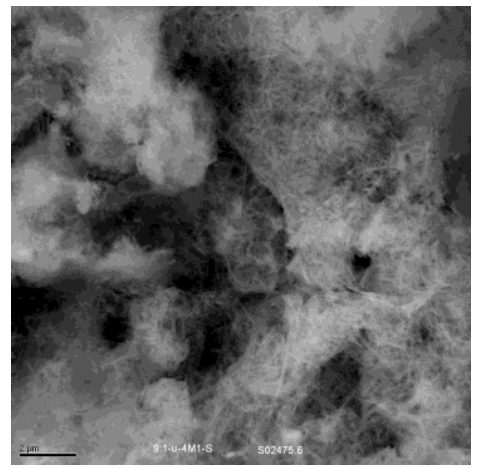

Figure 4.11. Scanning-Electron Photomicrographs of Solids Material from the Reaction of Uranophane in 9:1 BFS/OPC Pore water Displaying the Formation of Acicular, Fibrous Fine-Grained Crystal Tuffs

The equilibrium concentrations of primary elements U, Ca, P, and Si are presented in Error! Reference source not found. in the appendix. All concentrations are presented in molarity.

\subsection{Uranium Solubility Aqueous and Solid Phase Speciation Modeling}

The react program from the Geochemist Work Bench (GWB) geochemical model was applied to initial element concentrations to evaluate the aqueous speciation and saturation state of the effluent solutions with respect to key minerals, solids, and aqueous phases over time. The model was run in the presence of the each uranium mineral and the $\mathrm{pH}$ was slid to reflect the change from the initial $\mathrm{pH}$ to the 
final recorded $\mathrm{pH}$. The uranium species $\mathrm{CaUO}_{4}$ was suppressed during modeling because the high silicic acid concentrations found in the pore water favors the formation of uranium silicates over uranium oxide phases. Thermodynamic databases from numerous literature sources were used to update the computer codes (Alwan and Williams 1980; Chen et al. 1999; Finch 1997; Grenthe et al. 1992; Kalmykov and Choppin 2000; Langmuir 1978; Nguyen et al. 1992; O'Hare et al. 1976; Sergeyeva et al. 1972; Vochten and Haverbeke 1990). Because of the complex chemistry of uranium, there is significant debate regarding the stoichiometry and the thermodynamic values assigned to aqueous uranium species and secondary mineral phases. As such, the solubility calculations are based on current knowledge but may have significant uncertainty associated with them.

The aqueous concentration of uranium released from all potential $\mathrm{U}(\mathrm{VI})$-bearing solid phases in the simulated Portland cement-equilibrate pore waters ranged from $\log _{10}[\mathrm{U}(\mathrm{VI})]_{\mathrm{aq}}=-5$ to -9 , indicating that pore water cations and anions may be influencing the solubility of uranium through complexation (Table 4.6). The significance of $\mathrm{pH}$, and pore water cation and anions on the uranium mineral solubility, is also indicated by the formation of different secondary phases under differing cation and anion concentrations and changing $\mathrm{pH}$ regimes. Regarding the substantial change in $\mathrm{pH}$ seen in some samples over the course of the solubility experiments, note these experiments were run solely in the presence of concrete pore fluids; under normal solidification and stabilization conditions, concrete in contact with the pore fluids will keep the solution at highly alkaline values (> pH 12).

There was no observed effect of carbonate or sulfate within the pore waters on the stability of the uranyl minerals or on the formation of secondary phases. However, there was a clear effect of calcium and silicon in the pore waters on the stability of all uranium minerals, as well as on the formation of secondary phases. Results presented in Table 4.6 represent species that were saturated during the modeling reaction. The results do not indicate, for example, that all becquerelite will form uranophane in the OPC/BFS/L pore water. The modeling results indicate the speciation of secondary phases that could form under the chemical conditions found in the solubility experiments, but not the extent to which such transformation occurs. Autunite is a particularly clear example; uranium phosphates are among the most stable uranium phases, and the results from the solubility experiments indicate the autunite was fairly unreactive over the experimental duration. The modeling results for autunite yield a mix of silicate and phosphate phases; however, due to the stability of uranium phosphate minerals, the original phase will control the long-term release of uranium. Geochemical modeling results suggest the formation of 1) uranium silicate group minerals from soddyite, 2) uranium silicates and uranium oxyhydroxides from becquerelite, 3) uranophane reprecipitation from the dissolution of uranophane, and 4) uranium silicate and uranium phosphates from autunite.

The model simulation results for the aqueous speciation of uranium at the final $\mathrm{pH}$ are presented in Table 4.7. For soddyite, becquerelite, and uranophane the majority of uranium species at the final pHs are uranium hydroxides. Uranium carbonates form a large percentage of the total for the 9:1 BFS/OPC and OPC/BFS/L samples, which can be attributed to their elevated carbonate concentrations relative to other pore waters. The autunite samples were dominated by uranium phosphate species in the 9:1 BFS/OPC, OPC/BFS/L, and SRPC/L samples, with uranium hydroxides dominating the Harwell, and $\mathrm{OPC} / \mathrm{L}$ pore waters. 
Table 4.6. Thermodynamic Geochemical Modeling Results for Simulated Concrete Porefluids with Uranium Phases Identified as Primary Controls on Uranium Mobility in Concrete Waste Forms

\begin{tabular}{|c|c|c|c|c|}
\hline \multicolumn{5}{|c|}{ Soddyite } \\
\hline Pore water & $\begin{array}{c}\text { Initial } \\
\mathrm{pH}\end{array}$ & Final pH & Phase/End-Member & pH Range \\
\hline \multirow[t]{4}{*}{ 9:1 BFS/OPC } & 12.2 & 6.0 & $\mathrm{Na}_{2} \mathrm{U}_{2} \mathrm{O}_{7}$ & 11.0 to 11.5 \\
\hline & & & Uranophane: $\mathrm{Ca}\left(\mathrm{UO}_{2}\right)_{2} \mathrm{SiO}_{3}(\mathrm{OH})_{2} \cdot 5\left(\mathrm{H}_{2} \mathrm{O}\right)$ & 6.5 to 11.0 \\
\hline & & & Becquerelite: $\mathrm{Ca}\left(\mathrm{UO}_{2}\right)_{6} \mathrm{O}_{4}(\mathrm{OH})_{6} \bullet 8\left(\mathrm{H}_{2} \mathrm{O}\right)$ & 7.0 to 10.0 \\
\hline & & & Schoepite: $\left(\mathrm{UO}_{2}\right)_{8} \mathrm{O}_{2}(\mathrm{OH})_{12} \bullet 12\left(\mathrm{H}_{2} \mathrm{O}\right)$ & 6.0 to 7.0 \\
\hline $\mathrm{OPC} / \mathrm{BFS} / \mathrm{L}$ & 12.1 & 6.5 & Uranophane: $\mathrm{Ca}\left(\mathrm{UO}_{2}\right)_{2} \mathrm{SiO}_{3}(\mathrm{OH})_{2} \cdot 5\left(\mathrm{H}_{2} \mathrm{O}\right)$ & 6.5 to 11.0 \\
\hline Harwell & 12.0 & 5.0 & Uranophane: $\mathrm{Ca}\left(\mathrm{UO}_{2}\right)_{2} \mathrm{SiO}_{3}(\mathrm{OH})_{2} \cdot 5\left(\mathrm{H}_{2} \mathrm{O}\right)$ & 8.0 to 10.0 \\
\hline $\mathrm{OPC} / \mathrm{L}$ & 12.0 & 10.0 & Uranophane: $\mathrm{Ca}\left(\mathrm{UO}_{2}\right)_{2} \mathrm{SiO}_{3}(\mathrm{OH})_{2} \cdot 5\left(\mathrm{H}_{2} \mathrm{O}\right)$ & 10.0 to 11.0 \\
\hline \multirow[t]{3}{*}{$\mathrm{SRPC} / \mathrm{L}$} & 12.5 & 5.0 & Uranophane: $\mathrm{Ca}\left(\mathrm{UO}_{2}\right)_{2} \mathrm{SiO}_{3}(\mathrm{OH})_{2} \cdot 5\left(\mathrm{H}_{2} \mathrm{O}\right)$ & 6.5 to 11.5 \\
\hline & & & Becquerelite: $\mathrm{Ca}\left(\mathrm{UO}_{2}\right)_{6} \mathrm{O}_{4}(\mathrm{OH})_{6} \bullet 8\left(\mathrm{H}_{2} \mathrm{O}\right)$ & 7.0 to 11.0 \\
\hline & & & Schoepite: $\left(\mathrm{UO}_{2}\right)_{8} \mathrm{O}_{2}(\mathrm{OH})_{12} \bullet 12\left(\mathrm{H}_{2} \mathrm{O}\right)$ & 5.0 to 7.0 \\
\hline \multicolumn{5}{|c|}{ Becquerelite } \\
\hline Pore water & $\begin{array}{c}\text { Initial } \\
\mathrm{pH}\end{array}$ & Final pH & Phase/End-Member & pH Range \\
\hline \multirow[t]{3}{*}{ 9:1 BFS/OPC } & 12.2 & 7.5 & $\mathrm{Na}_{2} \mathrm{U}_{2} \mathrm{O}_{7}$ & 11.0 to 11.5 \\
\hline & & & Uranophane: $\mathrm{Ca}\left(\mathrm{UO}_{2}\right)_{2} \mathrm{SiO}_{3}(\mathrm{OH})_{2} \cdot 5\left(\mathrm{H}_{2} \mathrm{O}\right)$ & 7.5 to 11.0 \\
\hline & & & Becquerelite: $\mathrm{Ca}\left(\mathrm{UO}_{2}\right)_{6} \mathrm{O}_{4}(\mathrm{OH})_{6} \cdot 8\left(\mathrm{H}_{2} \mathrm{O}\right)$ & 7.5 to 8.0 \\
\hline $\mathrm{OPC} / \mathrm{BFS} / \mathrm{L}$ & 12.1 & 9.5 & Uranophane: $\mathrm{Ca}\left(\mathrm{UO}_{2}\right)_{2} \mathrm{SiO}_{3}(\mathrm{OH})_{2} \cdot 5\left(\mathrm{H}_{2} \mathrm{O}\right)$ & 9.5 to 10.5 \\
\hline Harwell & 12.0 & 9.0 & No phase predicted & N/A \\
\hline $\mathrm{OPC} / \mathrm{L}$ & 12.0 & 11.5 & $\mathrm{Na}_{2} \mathrm{U}_{2} \mathrm{O}_{7}$ & 11.5 to 12.0 \\
\hline $\mathrm{SRPC} / \mathrm{L}$ & 12.5 & 7.5 & Uranophane: $\mathrm{Ca}\left(\mathrm{UO}_{2}\right)_{2} \mathrm{SiO}_{3}(\mathrm{OH})_{2} \cdot 5\left(\mathrm{H}_{2} \mathrm{O}\right)$ & 8.5 to 9.5 \\
\hline \multicolumn{5}{|c|}{ Uranophane } \\
\hline Pore water & $\begin{array}{c}\text { Initial } \\
\mathrm{pH}\end{array}$ & Final $\mathrm{pH}$ & Phase/End-Member & pH Range \\
\hline 9:1 BFS/OPC & 12.2 & 9.0 & Uranophane: $\mathrm{Ca}\left(\mathrm{UO}_{2}\right)_{2} \mathrm{SiO}_{3}(\mathrm{OH})_{2} \cdot 5\left(\mathrm{H}_{2} \mathrm{O}\right)$ & 9 to 9.5 \\
\hline $\mathrm{OPC} / \mathrm{BFS} / \mathrm{L}$ & 12.1 & 10.0 & Uranophane: $\mathrm{Ca}\left(\mathrm{UO}_{2}\right)_{2} \mathrm{SiO}_{3}(\mathrm{OH})_{2} \cdot 5\left(\mathrm{H}_{2} \mathrm{O}\right)$ & 10.0 to 11.25 \\
\hline Harwell & 12.0 & 9.0 & Uranophane: $\mathrm{Ca}\left(\mathrm{UO}_{2}\right)_{2} \mathrm{SiO}_{3}(\mathrm{OH})_{2} \cdot 5\left(\mathrm{H}_{2} \mathrm{O}\right)$ & 9.0 to 9.5 \\
\hline $\mathrm{OPC} / \mathrm{L}$ & 12.0 & 9.0 & Uranophane: $\mathrm{Ca}\left(\mathrm{UO}_{2}\right)_{2} \mathrm{SiO}_{3}(\mathrm{OH})_{2} \cdot 5\left(\mathrm{H}_{2} \mathrm{O}\right)$ & 9.0 to 10.25 \\
\hline SRPC/L & 12.5 & 9.0 & Uranophane: $\mathrm{Ca}\left(\mathrm{UO}_{2}\right)_{2} \mathrm{SiO}_{3}(\mathrm{OH})_{2} \cdot 5\left(\mathrm{H}_{2} \mathrm{O}\right)$ & 9.0 to 11.0 \\
\hline \multicolumn{5}{|c|}{ Autunite } \\
\hline Pore water & $\begin{array}{c}\text { Initial } \\
\mathrm{pH}\end{array}$ & Final $\mathrm{pH}$ & Phase/End-Member & pH Range \\
\hline 9:1 BFS/OPC & 12.2 & 7.5 & Uranophane: $\mathrm{Ca}\left(\mathrm{UO}_{2}\right)_{2} \mathrm{SiO}_{3}(\mathrm{OH})_{2} \cdot 5\left(\mathrm{H}_{2} \mathrm{O}\right)$ & 7.5 to 10.5 \\
\hline $\mathrm{OPC} / \mathrm{BFS} / \mathrm{L}$ & 12.1 & 8.0 & Uranophane: $\mathrm{Ca}\left(\mathrm{UO}_{2}\right)_{2} \mathrm{SiO}_{3}(\mathrm{OH})_{2} \cdot 5\left(\mathrm{H}_{2} \mathrm{O}\right)$ & 8.0 to 11.0 \\
\hline Harwell & 12.0 & 6.5 & No phases predicted & N/A \\
\hline $\mathrm{OPC} / \mathrm{L}$ & 12.0 & 6.0 & No phases predicted & N/A \\
\hline $\mathrm{SRPC} / \mathrm{L}$ & 12.5 & 5.5 & $\left(\mathrm{UO}_{2}\right)_{3}\left(\mathrm{PO}_{4}\right)_{2} \cdot \mathrm{H} 2 \mathrm{O}$ & 5.5 \\
\hline
\end{tabular}


Table 4.7. Aqueous Speciation of GWB Simulation at Final pH

\begin{tabular}{|c|c|c|c|c|}
\hline \multicolumn{5}{|c|}{ Soddyite } \\
\hline Pore water & Initial $\mathrm{pH}$ & Final pH & Aqueous Species & $\%$ Total \\
\hline \multirow[t]{7}{*}{ 9:1 BFS/OPC } & 12.2 & 6.0 & $\left(\mathrm{UO}_{2}\right)_{3}(\mathrm{OH})_{5}^{+}$ & $34.95 \%$ \\
\hline & & & $\left(\mathrm{UO}_{2}\right)_{2} \mathrm{CO}_{3}(\mathrm{OH})_{3}$ & $29.29 \%$ \\
\hline & & & $\mathrm{UO}_{2}(\mathrm{OH})_{2}(\mathrm{aq})$ & $22.20 \%$ \\
\hline & & & $\left(\mathrm{UO}_{2}\right)_{4}(\mathrm{OH})_{7}^{+}$ & $7.98 \%$ \\
\hline & & & $\mathrm{UO}_{2} \mathrm{OH}^{+}$ & $2.99 \%$ \\
\hline & & & $\mathrm{UO}_{2} \mathrm{CO}_{3}$ & $1.91 \%$ \\
\hline & & & $\left(\mathrm{UO}_{2}\right)_{2}(\mathrm{OH})_{2}{ }^{2+}$ & $0.69 \%$ \\
\hline \multirow[t]{5}{*}{ OPC/BFS/L } & 12.1 & 6.5 & $\left(\mathrm{UO}_{2}\right)_{2}(\mathrm{OH})_{2}{ }^{2+}$ & $53.48 \%$ \\
\hline & & & $\left(\mathrm{UO}_{2}\right)_{2} \mathrm{CO}_{3}(\mathrm{OH})_{3}$ & $25.32 \%$ \\
\hline & & & $\mathrm{UO}_{2} \mathrm{CO}_{3}$ & $11.38 \%$ \\
\hline & & & $\mathrm{UO}_{2}\left(\mathrm{CO}_{3}\right)_{2}{ }^{2-}$ & $7.36 \%$ \\
\hline & & & $\mathrm{UO}_{2} \mathrm{OH}^{+}$ & $2.45 \%$ \\
\hline \multirow[t]{5}{*}{ Harwell } & 12.0 & 5.0 & $\mathrm{UO}_{2} \mathrm{SO}_{4}$ & $38.72 \%$ \\
\hline & & & $\mathrm{UO}_{2}^{2+}$ & $24.57 \%$ \\
\hline & & & $\mathrm{UO}_{2}\left(\mathrm{HPO}_{4}\right)_{2}{ }^{2-}$ & $17.00 \%$ \\
\hline & & & $\mathrm{UO}_{2} \mathrm{OH}^{+}$ & $11.52 \%$ \\
\hline & & & $\mathrm{UO}_{2}(\mathrm{OH})_{2}(\mathrm{aq})$ & $8.20 \%$ \\
\hline \multirow[t]{2}{*}{$\mathrm{OPC} / \mathrm{L}$} & 12.0 & 10.0 & $\mathrm{UO}_{2}(\mathrm{OH})_{3}^{-}$ & $92.85 \%$ \\
\hline & & & $\mathrm{UO}_{2}(\mathrm{OH})_{2}(\mathrm{aq})$ & $7.15 \%$ \\
\hline \multirow[t]{5}{*}{ SRPC/L } & 12.5 & 5.0 & $\left(\mathrm{UO}_{2}\right)_{3}(\mathrm{OH})_{5}^{+}$ & $34.56 \%$ \\
\hline & & & $\mathrm{UO}_{2}^{2+}$ & $26.23 \%$ \\
\hline & & & $\left(\mathrm{UO}_{2}\right)_{2}(\mathrm{OH})_{2}{ }^{2+}$ & $14.68 \%$ \\
\hline & & & $\mathrm{UO}_{2} \mathrm{OH}^{+}$ & $14.06 \%$ \\
\hline & & & $\mathrm{UO}_{2}(\mathrm{OH})_{2}(\mathrm{aq})$ & $10.47 \%$ \\
\hline \multicolumn{5}{|c|}{ Becquerelite } \\
\hline Pore water & Initial $\mathrm{pH}$ & Final $\mathrm{pH}$ & Aqueous Species & $\%$ Total \\
\hline \multirow[t]{5}{*}{ 9:1 BFS/OPC } & 12.2 & 7.5 & $\left.\mathrm{UO}_{2(} \mathrm{OH}\right)_{2}^{-2}$ & $48.97 \%$ \\
\hline & & & $\left(\mathrm{UO}_{2}\right)_{2} \mathrm{CO}_{3}(\mathrm{OH})_{3}$ & $46.89 \%$ \\
\hline & & & $\left.\mathrm{UO}_{2(} \mathrm{OH}\right)_{3}^{-}$ & $2.01 \%$ \\
\hline & & & $\mathrm{UO}_{2}\left(\mathrm{CO}_{3}\right)_{2}{ }^{2-}$ & $1.55 \%$ \\
\hline & & & $\mathrm{UO}_{2} \mathrm{CO}_{3}$ & $0.58 \%$ \\
\hline \multirow[t]{4}{*}{ OPC/BFS/L } & 12.1 & 9.5 & $\mathrm{UO}_{2}(\mathrm{OH})_{3}^{-}$ & $61.85 \%$ \\
\hline & & & $\mathrm{UO}_{2}\left(\mathrm{CO}_{3}\right) 3^{-}$ & $20.44 \%$ \\
\hline & & & $\left.\mathrm{UO}_{2(} \mathrm{OH}\right)_{2}{ }^{-2}$ & $14.27 \%$ \\
\hline & & & $\mathrm{UO}_{2}\left(\mathrm{CO}_{3}\right)_{2}{ }^{2-}$ & $3.44 \%$ \\
\hline \multirow[t]{2}{*}{ Harwell } & 12.0 & 9.0 & $\left.\mathrm{UO}_{2(} \mathrm{OH}\right)_{3}^{-}$ & $58.26 \%$ \\
\hline & & & $\mathrm{UO}_{2}(\mathrm{OH})_{2}{ }^{-2}$ & $41.74 \%$ \\
\hline \multirow[t]{2}{*}{$\mathrm{OPC} / \mathrm{L}$} & 12.0 & 11.5 & $\mathrm{UO}_{2}(\mathrm{OH})_{3}^{-}$ & $99.24 \%$ \\
\hline & & & $\left.\mathrm{UO}_{2(} \mathrm{OH}\right)_{4}$ & $0.76 \%$ \\
\hline \multirow[t]{3}{*}{ SRPC/L } & 12.5 & 7.5 & $\left.\mathrm{UO}_{2(} \mathrm{OH}\right)_{2}^{-2}$ & $93.79 \%$ \\
\hline & & & $\mathrm{UO}_{2}(\mathrm{OH})_{3}{ }^{-}$ & $3.85 \%$ \\
\hline & & & $\mathrm{UO}_{2}\left(\mathrm{CO}_{3}\right)_{2}{ }^{2-}$ & $2.35 \%$ \\
\hline
\end{tabular}


Table 4.7. (contd)

\begin{tabular}{|c|c|c|c|c|}
\hline \multicolumn{5}{|c|}{ Uranophane } \\
\hline Pore water & Initial $\mathrm{pH}$ & Final $\mathrm{pH}$ & Aqueous Species & $\%$ Total \\
\hline \multirow[t]{3}{*}{ 9:1 BFS/OPC } & 12.2 & 9.0 & $\left.\mathrm{UO}_{2(} \mathrm{OH}\right)_{3}{ }^{-}$ & $55.73 \%$ \\
\hline & & & $\mathrm{UO}_{2}(\mathrm{OH})_{2}{ }^{-2}$ & $42.81 \%$ \\
\hline & & & $\mathrm{UO}_{2}\left(\mathrm{CO}_{3}\right)_{2}{ }^{2-}$ & $1.46 \%$ \\
\hline \multirow[t]{4}{*}{ OPC/BFS/L } & 12.1 & 10.0 & $\mathrm{UO}_{2(}(\mathrm{OH})_{3}{ }^{-}$ & $83.65 \%$ \\
\hline & & & $\mathrm{UO}_{2}\left(\mathrm{CO}_{3}\right)_{3}{ }^{4-}$ & $9.77 \%$ \\
\hline & & & $\mathrm{UO}_{2}(\mathrm{OH})_{2}{ }^{-2}$ & $5.89 \%$ \\
\hline & & & $\mathrm{UO}_{2}\left(\mathrm{CO}_{3}\right)_{2}{ }^{2-}$ & $0.68 \%$ \\
\hline \multirow[t]{2}{*}{ Harwell } & 12.0 & 9.0 & $\mathrm{UO}_{2}(\mathrm{OH})_{3}^{-}$ & $57.83 \%$ \\
\hline & & & $\mathrm{UO}_{2}(\mathrm{OH})_{2}{ }^{-2}$ & $42.17 \%$ \\
\hline \multirow[t]{2}{*}{$\mathrm{OPC} / \mathrm{L}$} & 12.0 & 9.0 & $\mathrm{UO}_{2}(\mathrm{OH})_{3}^{-}$ & $56.43 \%$ \\
\hline & & & $\mathrm{UO}_{2}(\mathrm{OH})_{2}{ }^{-2}$ & $43.57 \%$ \\
\hline \multirow[t]{5}{*}{ SRPC/L } & 12.5 & 9.0 & $\mathrm{UO}_{2}(\mathrm{OH})_{3}{ }^{-}$ & $50.92 \%$ \\
\hline & & & $\mathrm{UO}_{2}(\mathrm{OH})_{2}{ }^{-2}$ & $39.19 \%$ \\
\hline & & & $\left(\mathrm{UO}_{2}\right)_{2} \mathrm{CO}_{3}(\mathrm{OH})_{3}$ & $8.75 \%$ \\
\hline & & & $\mathrm{UO}_{2}\left(\mathrm{CO}_{3}\right)_{2}{ }^{2-}$ & $0.90 \%$ \\
\hline & & & $\mathrm{UO}_{2}\left(\mathrm{CO}_{3}\right)_{3}{ }^{4-}$ & $0.24 \%$ \\
\hline \multicolumn{5}{|c|}{ Autunite } \\
\hline Pore water & Initial $\mathrm{pH}$ & Final $\mathrm{pH}$ & Aqueous Species & $\%$ Total \\
\hline \multirow[t]{4}{*}{ 9:1 BFS/OPC } & 12.2 & 7.5 & $\mathrm{UO}_{2} \mathrm{PO}_{4}^{-}$ & $58.08 \%$ \\
\hline & & & $\mathrm{UO}_{2}(\mathrm{OH})_{2}(\mathrm{aq})$ & $31.96 \%$ \\
\hline & & & $\left(\mathrm{UO}_{2}\right)_{2} \mathrm{CO}_{3}(\mathrm{OH})_{3}^{-}$ & $5.97 \%$ \\
\hline & & & $\mathrm{UO}_{2}\left(\mathrm{HPO}_{4}\right)_{2}{ }^{2-}$ & $3.99 \%$ \\
\hline \multirow[t]{5}{*}{ OPC/BFS/L } & 12.1 & 8.0 & $\mathrm{UO}_{2} \mathrm{PO}_{4}^{-}$ & $75.02 \%$ \\
\hline & & & $\mathrm{UO}_{2}(\mathrm{OH})_{2}(\mathrm{aq})$ & $14.71 \%$ \\
\hline & & & $\mathrm{UO}_{2}\left(\mathrm{CO}_{3}\right)_{2}{ }^{2-}$ & $5.07 \%$ \\
\hline & & & $\left(\mathrm{UO}_{2}\right)_{2} \mathrm{CO}_{3}(\mathrm{OH})_{3}^{-}$ & $2.16 \%$ \\
\hline & & & $\mathrm{UO}_{2} \mathrm{CO}_{3}(\mathrm{aq})$ & $1.15 \%$ \\
\hline \multirow[t]{2}{*}{ Harwell } & 12.0 & 6.5 & $\mathrm{UO}_{2}(\mathrm{OH})_{2}(\mathrm{aq})$ & $93.32 \%$ \\
\hline & & & $\mathrm{UO}_{2} \mathrm{PO}_{4}^{-}$ & $6.68 \%$ \\
\hline \multirow[t]{3}{*}{$\mathrm{OPC} / \mathrm{L}$} & 12.0 & 6.0 & $\mathrm{UO}_{2}(\mathrm{OH})_{2}(\mathrm{aq})$ & $79.18 \%$ \\
\hline & & & $\mathrm{UO}_{2} \mathrm{OH}^{+}$ & $10.41 \%$ \\
\hline & & & $\mathrm{UO}_{2}\left(\mathrm{HPO}_{4}\right)_{2}{ }^{2-}$ & $10.41 \%$ \\
\hline \multirow[t]{4}{*}{$\mathrm{SRPC} / \mathrm{L}$} & 12.5 & 5.5 & $\mathrm{UO}_{2}\left(\mathrm{HPO}_{4}\right)^{2-}$ & $69.58 \%$ \\
\hline & & & $\mathrm{UO}_{2}(\mathrm{OH})_{2}(\mathrm{aq})$ & $14.32 \%$ \\
\hline & & & $\mathrm{UO}_{2} \mathrm{PO}_{4}^{-}$ & $10.05 \%$ \\
\hline & & & $\mathrm{UO}_{2} \mathrm{OH}^{+}$ & $6.05 \%$ \\
\hline
\end{tabular}

\subsection{EXAFS Analysis of Uranium Solubility Solids}

Although SEM-EDS and XRD provided preliminary information regarding the possible secondary phases that form and may control uranium mobility in concrete pore fluids, limited structural and speciation information on phases present at $<5 \mathrm{wt} \%$ were provided. Therefore, to precisely understand 
the mechanisms of transformation and identity of uranium phases controlling the long-term mobility of uranium in concrete waste forms, EXAFS analysis was conducted on pristine uranium phases, and the uranium phases reacted with simulated concrete pore fluids.

Uranium $\mathrm{L}_{\mathrm{III}}$ EXAFS measurements of the samples were conducted at room temperature on the Molecular Environmental Sciences Beamline 11-2 (Bargar et al. 2002) at the Stanford Synchrotron Radiation Laboratory using a cryogenically cooled Si (220), $\phi=0^{\circ}$, double-crystal monochromator. Fluorescence-yield data were collected using a high throughput 30-element solid-state Ge detector. A collimating mirror before the monochromator was used for harmonic rejection, with a cutoff of $19.6 \mathrm{keV}$. Yttrium metal foil was mounted between two ionization chambers downstream of the sample for energy calibration; the first inflection point in the yttrium K-edge was set to $17038 \mathrm{eV}$. Backgroundsubtracted $\mathrm{k}^{3}$-weighted EXAFS data were analyzed using the SixPACK (Webb 2004) interface to IFEFFIT(Newville 2001). Data were fit as linear combinations of the $\chi$ data from $\mathrm{k}=3-12, \mathrm{k}^{3}$ weighted for the original uranium mineral and potential secondary phase minerals. A suite of model compound combinations were run to determine the best possible fit of the spectra. Combinations of autunite, schoepite, boltwoodite, uranium rich calcite, soddyite, and uranophane were run based on starting mineral, pore water chemistry, and secondary phases suggested from SEM-EDS analysis and geochemical modeling. Samples were selected based on results from SEM-EDS and geochemical modeling, which indicated the formation of secondary phases.

Figure 4.12 shows EXAFS analysis of autunite minerals in Harwell and OPC/BFS/L porewaters for 3.5 months and 1 year. The spectra indicate the retention of uranium phosphate minerals over the course of 3.5 months and 1 year for both the Harwell and OPC/BFS/L porewaters. The results of linear combination fits for Figure 4.12 are presented in Table 4.8. The fits were well fit using solely autunite. The fits indicate that Harwell reacted autunite was $95 \%$ autunite after 3.5 months and $89 \%$ autunite after 1 year. When fitting EXAFS spectra, a linear combination equaling 100\% is rare. As with all modeling

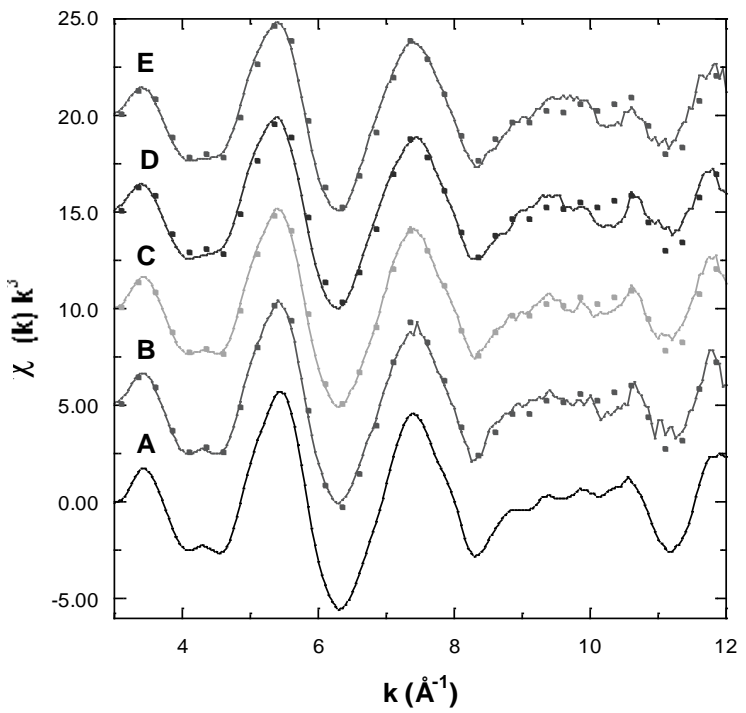

Figure 4.12. EXAFS of 3.5 and 1 Year Autunite Mineral Tests (a) Autunite Mineral, (b) Harwell Reacted Autunite After 3.5 Months (HAR_A_3.5M), (c) Harwell Reacted Autunite After 1 Year (HAR_A_1YR), (d) BFS Reacted Autunite After 3.5 Months (BFS_A_3.5M), and (e) BFS Reacted Autunite After 1 Year. The dots are the best fit to the EXAFS spectra using linear combination of autunite and uranophane mineral. 
Table 4.8. Results of Linear Combination Fit of Autunite Mineral Tests

\begin{tabular}{cc}
\hline & Autunite \\
\hline HAR_A_3.5M & 0.95 \\
HAR_A_1YR & 0.89 \\
BFS_A_3.5M & 0.84 \\
BFS_A_1YR & 0.85 \\
SRPC_A_3.5M & 0.93 \\
\hline
\end{tabular}

and spectroscopic fitting, there is a degree of uncertainty that results in a less than $100 \%$ fit. Harwell autunite reacted for 3.5 months is well fit as a 95\% linear combination fit for autunite. Harwell autunite reacted for 1 year is well fit with an $89 \%$ linear combination. This indicates the material is predominately autunite; the exact composition did not fit the model compounds. It is possible the low percentage of the fit is due to a change in cation (from calcium to sodium or magnesium). The OPC/BFS/L reacted autunite was $84 \%$ autunite after 3.5 months and $85 \%$ autunite after 1 year. As above, the best-fit spectra consisted of solely autunite.

Figure 4.13 shows the EXAFS spectra for autunite reacted for 3.5 months in Harwell, OPC/BFS/L, and SRPC porewaters. As in Figure 4.12, the EXAFS spectra indicate that after 3.5 months in the different concrete porewaters, the autunite was either unreactive or transformed to another uranium phosphate phase. Table 4.8 gives the results of linear combination fits from the 3.5 month reacted autunite mineral experiments. The autunite reacted in SRPC pore water for 3.5 months was best fit as 95\% autunite.

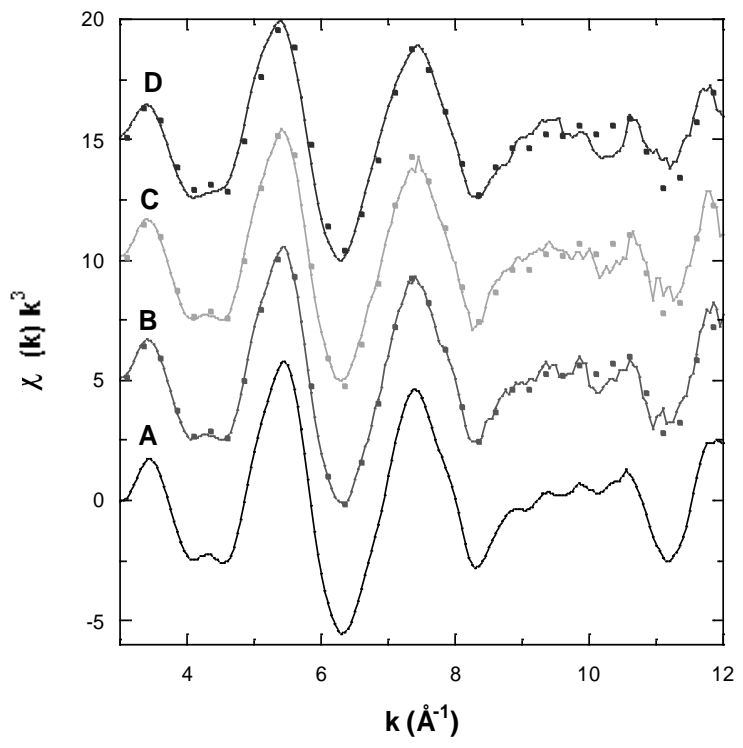

Figure 4.13. EXAFS of 3.5 Month Reacted Autunite Mineral Tests (a) Autunite Mineral, (b) SRPC Reacted Autunite After 3.5 Months, (c) Harwell Reacted Autunite After 3.5 Months, and (d) BFS Reacted Autunite After 3.5 Months. The dots are the best fit to the EXAFS spectra using linear combination of autunite. 
Uranium phosphate minerals are structurally very similar, which affords spectroscopic analyses that are relatively indistinguishable from one another (Catalano and Jr. 2004). Because autunite was the known starting phase within these experiments, the reacted minerals were fit using autunite as a model mineral for comparison. However, it cannot be ascertained from EXAFS data alone whether the autunite mineral tests were stable over the duration of the test or if secondary uranium-phosphate phases were also formed. SEM-EDS analysis supported the formation of secondary phase(s) on the autunite reacted samples, with mixed sodium-calcium uranium phosphates tentatively identified through EDS analysis. The combination of SEM imaging, which showed secondary phase formation; EDS analysis, which indicated the formation of uranium phosphate secondary phases; and EXAFS linear combination fits, which indicated the reacted autunite sample contained only uranium phosphates, support the hypothesis that in contact with Portland cement pore waters, autunite undergoes a dissolution-precipitation reaction that results in the formation of uranium phosphate species. From these results, the ability of concrete waste forms to retain uranium is high, due to the re-precipitation of high stability phosphate phases. Among the paragenetic sequence of uranium, phosphate species are among the most stable.

Figure 4.14 and Table 4.9 show the results from EXAFS analysis of soddyite mineral tests. Provided in Figure 4.14 are the EXAFS spectra of soddyite and uranophane model compounds, Harwell reacted soddyite after 3.5 months, OPC/L reacted soddyite after 3.5 months, and OPC/BFS/L reacted soddyite after 3.5 months. Based on the sharpening of the peak between $\mathrm{k} 7$ and 8 , the introduction of the uranophane hump around $\mathrm{k} 9.2$, and the minimization of the soddyite peak at $\mathrm{k} 10$, the EXAFS spectra indicate that soddyite changes to a mixture of soddyite uranophane across the three different pore waters (Harwell, OPC/L, and OPC/BFS/L). Table 4.9 lists the results from the linear combination fits. The spectra were well fit using a mixture of soddyite and uranophane. For the Harwell-reacted soddyite, the best fit was 59\% soddyite and 33\% uranophane; for OPC/L it was 55\% soddyite and 33\% uranophane and for OPC/BFS/L it was $19 \%$ soddyite and $72 \%$ uranophane. These results indicate that irrespective of pore water silicate concentration, soddyite minerals transform into a more stable uranophane group mineral, which will further control the stability of these minerals within concrete pore waters. These results correspond to geochemical modeling and SEM-EDS data that suggested the formation of uranophane/becquerelite group mineral phases for the soddyite mineral tests (Wellman et al. 2008; Mattigod et al. 2009).

Figure 4.15 shows EXAFS analysis of uranophane minerals in Harwell and OPC/BFS/L, and OPC/L pore waters for 3.5 months. The spectra indicate the stability of uranophane group minerals under these conditions. The results of linear combination fits for Figure 4.15 are presented in Table 4.10. The fits were well fit using solely uranophane. The linear combination fits resulted in fits of 94 to 100\% uranophane across all three pore waters. These results are consistent with previous investigations into uranium retention in concrete, which suggested the primary coordination of uranium in these environments is that of uranophane (Harfouche et al. 2006; Kienzler et al. 2010; Wieland et al. 2010). These results are also consistent with SEM-EDS analysis that indicated secondary phases did not form during the uranophane experiments. In addition, modeling results indicate that any secondary phases that formed under these conditions would be dominated by the uranophane phase.

EXAFS analysis of the becquerelite mineral test was performed. However, a suitable model compound for becquerelite was not available and linear combination fits were unable to be performed. 


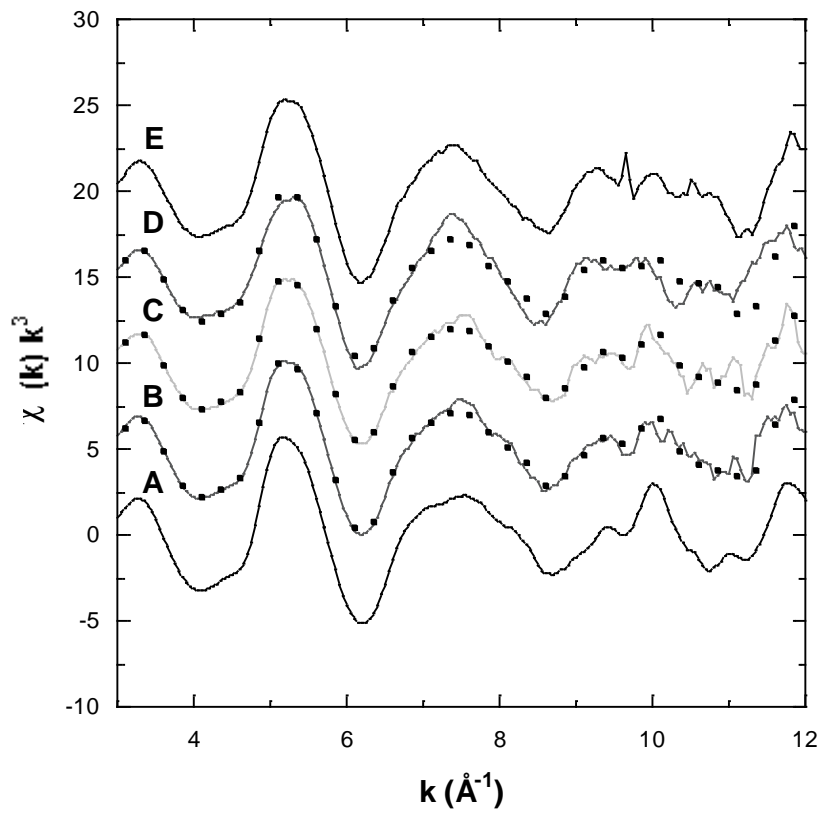

Figure 4.14. EXAFS of 3.5 Month Reacted Soddyite Mineral Tests (a) Soddyite Mineral, (b) Harwell Reacted Soddyite After 3.5 Months, (c) OPC/L Reacted Soddyite After 3.5 Months,

(d) BFS Reacted Soddyite After 3.5 Months, and (e) Uranophane Mineral. The dots are the best fit to the EXAFS spectra using linear combination of soddyite and uranophane.

Table 4.9. Results of Linear Combination Fit of Soddyite Mineral Tests

\begin{tabular}{lcc}
\hline & Soddyite & Uranophane \\
\hline HAR_S_3.5M & 0.59 & 0.33 \\
OPC_S_3.5M & 0.55 & 0.33 \\
BFS_S_3.5M & 0.19 & 0.72 \\
\hline
\end{tabular}




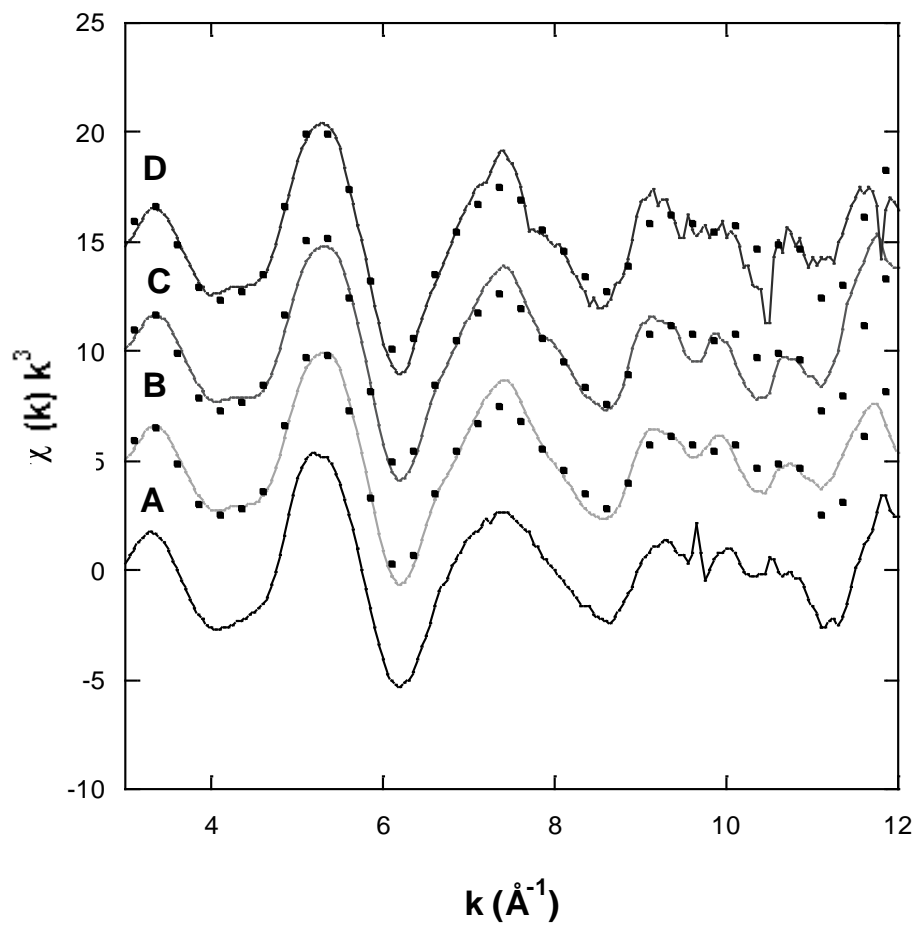

Figure 4.15. EXAFS of 3.5 Month Reacted Uranophane Mineral Tests (a) Uranophane Mineral, (b) BFS Reacted Uranophane After 3.5 Months, (c) Harwell Reacted Uranophane After 3.5 Months, and (d) OPC/L Reacted Uranophane After 3.5 Months. The dots are the best fit to the EXAFS spectra using linear combination of uranophane.

Table 4.10. Results of Linear Combination Fit of Uranophane Mineral Tests

\begin{tabular}{lc}
\hline & Uranophane \\
\hline BFS_U_3.5M & 0.94 \\
Har_U_3.5M & 1.00 \\
OPC_U_3.5M & 0.97 \\
\hline
\end{tabular}




\subsection{Summary of Uranium Solubility in Vadose Zone Sediment}

There are variations in the sedimentary, hydrologic and geochemical properties within the vadose zone of the Hanford Site, as well as from region to region. These differences will have an effect on the speciation and mobility of uranium within these regions. Understanding the phases of uranium found within the vadose zone is pivotal to remediation efforts and the prediction of long-term uranium mobility. Zachara et al. composed a detailed reference that is a summary of uranium geochemistry at the Hanford Site (Zachara et al. 2007). In 2008, Peterson et al. summarized the uranium contamination beneath the 300 Area at the Hanford Site (Peterson et al. 2008). McKinley et al. discuss the contamination and characterization of samples from the 200 Area BX tank farm and the 300 Area Process Pond (McKinley et al. 2007), some of which is briefly described below.

Samples from multiple boreholes in various locations through the Hanford Site have been collected and characterized using X-ray absorption fine structure (XAFS), X-ray fluorescence (XRF), and timeresolved laser induced fluorescence (TRLIF) to determine speciation found within the samples. In 2002, Catalano et al. showed that vadose zone sediments collected from borehole 299-E33-45 under the BX-102 single-shell tank contained species from the uranophane group, specifically sodium boltwoodite (Catalano et al. 2004; Catalano et al. 2002). Fluorescence emission and time-resolved fluorescence of sediments revealed the presence of one dominant fluorescence species whose composition/structure was not changed by the electrolyte. Sediment spectra were not exact matches for any of the reference materials, but similar to the uranophane group. Best fit of data came from a combination of boltwoodite (53\%), uranophane (42\%), and soddyite (4\%) (Wang et al. 2005; McKinley et al. 2006). Liu et al. found that uranyl silicate microprecipitates in fractures, cleavages, and cavities within Hanford Site sediment samples (Liu et al. 2004). Laser-induced fluorescence spectroscopy revealed the observed species remained unchanged by the dissolution process. Depending on experimental conditions, steady-state concentrations of aqueous $\mathrm{U}(\mathrm{VI})$ ranged from 8.4 to $231 \mu \mathrm{M}$, which are consistent with the solubility of Na-boltwoodite and/or uranophane (Liu et al. 2004; Ilton et al. 2008). Studies of sediments collected from boreholes (C5124, C5132, and C5134) near the BX-101 and BX-102 tanks also showed the dominating uranium species to be uranophane and boltwoodite. The presence of uranyl phosphates, possibly in the form of autunite, were also observed during these experiments (Um et al. 2010).

Experimental results by Um et al. from samples collected at borehole C5602 (near the U-104 and U-105 tanks) show that U(VI) exists as different surface phases as a function of depth below ground surface (Um et al. 2009). Boltwoodite and uranophane species dominate at shallow depths (15-16 m). Adsorbed U(VI) phases and polynuclear surface precipitates were found at intermediate depths (20-25 m). At depths greater than $28 \mathrm{~m}$, only natural uranium was found (Um et al. 2009). The summary by Peterson et al. suggests that the native uranium in Hanford sediments is from the betafite group (Peterson et al. 2008). Structurally similar to brannerite, betafite is highly resistant to weathering (Lumpkin and Ewing 1996).

Sediments gathered from locations near the 300 Area North Process Ponds have also been characterized. Uranyl copper-phosphate has been identified (Arai et al. 2007; Stubbs et al. 2009; Singer et al. 2009; Ilton et al. 2010), as well as uranyl silicate materials (Brown et al. 2010). In addition to finding uranium in mineral form, uranium was also found in zirconium-rich amorphous material, void linings in basalt clasts, banded palagonite surrounding fragments of glass; and iron- and manganeseoxides (Stubbs et al. 2009). 
The observations made on Hanford Site sediment differ from investigations of soil from DOE Fernald site in Ohio. In the Fernald sediments, three different types of precipitates were observed: an autunitelike phase, a schoepite-like phase, and an uranyl organic phase that was not well defined (Morris et al. 1996). At both the Hanford Site and Fernald site, similar uranium concentrations and significant phosphate are found in the sediment samples. In Hanford Site soils, preferential formation of uranophane is possibly due to 1) unweathered silicates in sediment; 2) silicon dissolution brought on by $\mathrm{pH}(9-10)$ and temperatures $\left(60^{\circ} \mathrm{C}\right.$ to $\left.80^{\circ} \mathrm{C}\right) ; 3$ ) presence of $\mathrm{Ca}^{2+}$ to react and precipitate with $\mathrm{PO}_{4}{ }^{3-}$; and 4) low water content found within the sediment (Wang et al. 2005). Sodium-calcium uranyl tricarbonates and $\mathrm{U}(\mathrm{VI})$-hydroxide or hydroxycarbonate precipitates were found in California evaporation pond sediment (Duff et al. 2000). 


\subsection{Conclusions}

The solubility of uranium phases in contact with concrete pore water has been investigated using aqueous chemical analysis, SEM-EDS, geochemical modeling, and EXAFS analysis. The results suggest the following:

- The time it took to reach steady-state concentrations of aqueous uranium varied greatly. In all pore waters, uranophane reached equilibrium in $<30$ days. In some cases, equilibrium had not been reached after 403 days.

- There was no observed effect of carbonate or sulfate within the porewaters on the stability of the uranyl minerals or on the formation of secondary phases. However, there was a clear effect of calcium and silicon in the pore waters on the stability of all uranium minerals, as well as on the formation of secondary phases.

- The formation of uranium silicate group minerals from soddyite, uranium silicates and uranium oxyhydroxides from becquerelite, uranophane reprecipitation from the dissolution of uranophane, and uranium silicate and uranium phosphates from autunite.

The characterization of uranium phases in vadose zone sediments indicate that:

- Throughout the Hanford Site, uranium was found as uranyl silicates (as boltwoodite and uranophane), uranyl phosphates (as autunite) and as uranyl copper phosphate (near the 300 North Processing Ponds).

- Natural uranium was suggested to be in the form of betafite, a mineral highly resistant to weathering.

- At the DOE Fernald site in Ohio, uranium was found as an autunite-like phase, a schoepite-like phase, and an undefined uranyl-organic phase. 


\subsection{References}

Allison, JD, DS Brown, and KJ Novo-Gradac. 1991. Minteqa2/Prodefa2, a Geochemical Assessment Model for Environmental Systems: Version 3 User's Manual. Report, Environmental Research Laboratory, Office of Research and Development, U.S. EPA, Athens, Georgia.

Altenhein-Hasse, C, H Bischoff, L Fu, J Mao, and G Marx. 1994. "Adsorption of Actinides on Cement Compounds." Journal of Alloys and Compounds 213/214:554-56.

Alwan, AK and PA Williams. 1980. "The Aqueous Chemistry of Uranium Minerals. Part 2. Minerals of the Liebigite Group." Mineralogical Magazine 43:665-67.

Arai, Y, MK Marcus, N Tamura, JA Davis, and JM Zachara. 2007. "Spectroscopic Evidence for Uranium Bearing Precipitates in Vadose Zone Sediments at the Hanford 300-Area Site." Environmental Science \& Technology 41(13):4633-39. 10.1021/es062196u.

Atkins, M, AN Beckley, and FP Glasser. 1988. "Influence of Cement on the near Field Environment and Its Specific Interactions with Uranium and Iodine." Radiochimica Acta 44/45:255-61.

Atkins, M and FP Glasser. 1990. Encapsulation of Radioiodine in Cementitious Waste Forms. Scientific Basis for Nuclear Waste Management Xiii 176.

Baes, J, C.F., JM Schreyer, and JM Lesser. 1953. The Chemistry of Uranium (Vi) Orthophosphate Solutions: Part I. A Spectrophotometric Investigation of Uranyl Phosphate Complex Formation in Perchloric Acid Solution. Report, Oak Ridge National Laboratory, Oak Ridge, Tennessee.

Bargar, JR, GEB Jr., I Evans, T Rabedeau, M Rowen, and J Rogers. 2002. "A New Hard X-Ray Xafs Spectorscopy Facility for Environmetnal Samples, Including Actinides, at the Stanford Synchrotron Radiation Laboratory.

Precedings of the Euroconference and Nea Workshop on Seciation, Techniques and Facilities for Radioactive Materials at Synchrotron Light Sources." NEA/OECD Paris:57-68.

Bates, JK, BS Tani, E Veleckis, and DJ Wronkiewicz. 1990. Identification of Secondary Phases Formed During Unsaturated Reaction of Uo2 with Ej-13 Water. Scientific Basis for Nuclear Waste Management Xiii 176.

Bogue, RH. 1955. Chemistry of Portland Cement. Reinhold Publishing Corporation, New York.

Brown, CF, RJ Serne, JG Catalano, KM Krupka, and JP Icenhower. 2010. "Mineralization of Contaminant Uranium and Leach Rates in Sediments from Hanford, Washington." Applied Geochemistry 25(1):97-104. 10.1016/j.apgeochem.2009.10.005.

Brownsword, M, AB Buchan, FT Ewart, R McCrohon, GJ Ormerod, JL Smith-Briggs, and HP Thomason. 1990. The Solubility and Sorption of U(Vi) in a Cementitious Repository. In Proceedings of Materials Research Symposium Society Proceedings, 557-82 pp.

Carroll, SA and J Bruno. 1991. "Mineral-Solution and Interactions in the U(Vi)- $\mathrm{Co}_{2}-\mathrm{H}_{2} \mathrm{O}$ System." Radiochimica Acta 52/53:187-93. 
Carroll, SA, J Bruno, JC Petit, and JC Dran. 1992. "Intractions of U(Vi), Nd, and Th(Iv) at the CalciteSolution Incterface." Radiochimica Acta 58/59:245-52.

Casas, I, J Bruno, E Cera, RJ Finch, and RC Ewing. 1994. Kinetic and Thermodynamic Studies of Uranium Minerals. Assessment of the Long-Term Evolution of Spent Nuclear Fuel. Report.

Catalano, JG, SC Heald, JM Zachara, and GE Jr. Brown. 2004. "Spectroscopic and Diffraction Study of Uranium Speciation in Contaminated Vadose Zone Sediments from the Hanford Site, Washington State." Environmental Science and Technology 38:2822-28.

Catalano, JG and GEB Jr. 2004. "Analysis of Uranyl-Bearing Phases by Exafs Spectroscopy: Interferences, Multiple Scattering, Accuracy of Structural Parameters, and Spectral Differences." American Mineralogist 89:1004-21.

Catalano, JG, JA Warner, CC Ainsworth, JM Zachara, SJ Traina, and GE Brown. 2002. "Xafs Studies of Chromium and Uranium Speciation in Hanford Vadose Zone Sediments." Abstracts of Papers of the American Chemical Society 223:U612-U12.

Chen, F, RC Ewing, and SB Clark. 1999. "The Gibbs Free Energies and Enthalpies of Formation of U ${ }^{6+}$ Phases: An Empirical Method of Prediction." American Mineralogist 84:650-64.

Clark, DL, DE Hobart, and MP Neu. 1995. "Actinide Carbonate Complexes and Their Importance in Actinide Environmental Chemistry." Chemical Reviews 95:25 - 48.

Cooper, MJ and DP Hodgkinson. 1987. Report.

Cordfunke, EHP. 1969. The Chemistry of Uranium. Elsevier Publishing Company, Amsterdam, The Netherlands.

Cordfunke, EHP. 1964. "Heats of Formation of Some Hexavalent Uranium Compounds." Journal of Physcial Chemistry 68(11):3353-56.

Criscenti, LJ, RJ Serne, KM Krupa, and MI Wood. 1996. Predictive Calculations to Assess the LongTerm Effect of Cemtentitious Materials on the Ph and Solubility of Uranium (Vi) in a Shallow and Disposal Environment. Report, Pacific Northwest National Laboratory, Richland, WA.

Denecke, MA, J Rothe, K Dardenne, and P Lindqvist-Reis. 2003. "Grazing Incidence (Gi) Xafs Measurements of Hf(Iv) and U(Vi) Sorption onto Mineral Surfaces." Physical Chemisty, Chemical Physics 5:939-46.

Duff, MC, DE Morris, D Hunter, B., and PM Bertsch. 2000. "Spectroscopic Characterization of Uranium in Evaporation Basin Sediments." Geochimica et Cosmochimica Acta 64(9):1535-50.

Duff, MC, J Urbanik-Coughlin, and D Hunter, B. 2002. "Uranium Co-Precipitation with Iron Oxide Minerals." Geochimica et Cosmochimica Acta 66(20):3533-47.

Erikson, RL, CJ Hostetler, RJ Serne, JR Divine, and MA Parkhurst. 1993. Geochemical Factors Affecting Degradation and Environmental Fate of Depleted Uranium Penetrators in Soil and Water. Report No. PNL-8527, Pacific Northwest Nation Laboratory, Richland, WA. 
Ewart, FT, JL Smith-Briggs, HP Thomason, and SJ Williams. 1992. "The Solubility of Actinides in a Cementitious near-Field Environment." Waste Management 12:241-52.

Finch, RJ. 1997. "Thermodynamic Stabilities of U(Vi) Minerals: Estimated and Observed Relationships." Material Research Society Symposium Proceedings 465:1185-92.

Finch, RJ and R Ewing. 1990. Uraninite Alteration in an Oxidizing Environment and Its Relevance to the Disposal of Spent Nuclear Fuel. Report No. SKB Technical Report 91-15, Svensk Kärnbränslehantering AB (Swedish Nuclear Fuel and Waste Management Company), Stockholm, Sweden.

Finch, RJ and RC Ewing. 1992a. Alteration of Natural Uranyl Oxide Hydrates in Si-Rich Groundwaters Implications for Uranium Solubility. Scientific Basis for Nuclear Waste Management Xv 257.

Finch, RJ and RC Ewing. 1992b. "The Corrosion of Uraninite under Oxidizing Conditions." Journal of Nuclear Materials 190:133-56.

Finch, RJ and RC Ewing. 1991. Phase-Relations of the Uranyl Oxide Hydrates and Their Relevance to the Disposal of Spent Fuel. Scientific Basis for Nuclear Waste Management Xiv 212.

Finch, RJ, J Suksi, K Rasilainen, and RC Ewing. 1995. "The Long-Term Stability of Becquerelite." In Scientific Basis for Nuclear Waste Management Xviii, Pts 1 and 2, ed. TERC Murakami, Vol 353, pp. 647-52.

Garrels, RM and CL Christ. 1965. Solutions, Minerals and Equilibria. Harper and Row Publ. Co., New York.

Glasser, FP. 2001. "Mineralogical Aspects of Cement in Radioactive Waste Disposal." Mineralogical Magazine 65(5):621-33.

Glasser, FP, AA Rahman, D Macphee, MJ Angus, and M Atkins. 1985. Immobilization of Radioactive Waste in Cement-Based Matrices. Report, University of Aberdeen, Old Aberdeen.

Gorman-Lewis, D, PC Burns, and JB Fein. 2008a. "Review of Uranyl Mineral Solubility Measurements." Journal of Chemical Thermodynamics 40(3):335-52. DOI 10.1016/j.jct.2007.12.004.

Gorman-Lewis, D, JB Fein, PC Burns, JES Szymanowski, and J Converse. 2008b. "Solubility Measurements of the Uranyl Oxide Hydrate Phases Metaschoepite, Compreignacite, Na-Compreignacite, Becquerelite, and Clarkeite." Journal of Chemical Thermodynamics 40(6):980-90. 10.1016/j.jct.2008.02.006.

Gorman-Lewis, D, T Shvareva, KA Kubatko, PC Burns, DM Wellman, B McNamara, JES Szymanowski, A Navrotsky, and JB Fein. 2009. "Thermodynamic Properties of Autunite, Uranyl Hydrogen Phosphate, and Uranyl Orthophosphate from Solubility and Calorimetric Measurements." Environmental Science \& Technology 43(19):7416-22. 10.1021/es9012933.

Grambow, B. 1989. Spent Fuel Dissolution and Oxidation: An Evaluation of Literature Data. Report, Hanh-Meitner-Institut, Berlin.

Greenfield, BF, DJ Ilett, M Ito, R McCrohon, TG Heath, CJ Tweed, SJ Williams, and M Yui. 1998. "The Effect of Cement Additives on Radionuclide Solubilities." Radiochimica Acta 82:27-32. 
Grenthe, I, J Fuger, RJM Konings, RJ Lemire, AB Muller, C Nguyen-Trung, and H Wanner. 1992. Chemical Thermodynamics of Uranium. Chemical Thermodynamics 1, OECD Nuclear Energy Agency, Amsterdam.

Harfouche, M, E Wieland, R Dahn, T Fujita, J Tits, D Kunz, and M Tsukamoto. 2006. "Exafs Study of U(Vi) Uptake by Calcium Silicate Hydrates." Journal of Colloid and Interface Science 303(1):195-204. 10.1016/j.jcis.2006.07.019.

Ilton, ES, C Liu, W Yantasee, Z Wang, DA Moore, AR Felmy, and JM Zachara. 2006. "The Dissolution of Synthetis Na-Boltwoodite in Sodium Carbonate Solutions." Geochimica et Cosmochimica Acta 70:4836-49.

Ilton, ES, NP Qafoku, C Liu, DA Moore, and JM Zachara. 2008. "Advective Removal of Intraparticle Uranium from Contaminated Vadose Zone Sediments, Hanford, U.S." Environmental Science \& Technology 42:1565-71.

Ilton, ES, JM Zachara, DA Moore, JP McKinley, AD Eckberg, CL Cahill, and AR Felmy. 2010. "Dissolution Study of Metatorbernite: Thermodynamic Properties and the Effect of Ph and Phosphate." Environmental Science \& Technology 44(19):7521-26. 10.1021/es101619f.

Janeczek, J and RC Ewing. 1992a. "Dissolution and Alteration of Uraninite under Reducing Conditions." Journal of Nuclear Materials 190:157-73. 10.1016/0022-3115(92)90084-x.

Janeczek, J and RC Ewing. 1992b. "Structural Formula of Uraninite." Journal of Nuclear Materials 190:128-32. 10.1016/0022-3115(92)90082-v.

Kalmykov, SN and GR Choppin. 2000. "Mixed $\mathrm{Ca}^{2+} / \mathrm{Uo}_{2}{ }^{2+} / \mathrm{Co}_{3}{ }^{2-}$ Complex Formation at Different Ionic Strengths." Radiochimica Acta 88:603-06.

Kaplan, DI, TL Gervais, and KM Krupka. 1998. "Uranium (Vi) Sorption to Sediments under High Ph and Ionic Strength Conditions." Radiochimica Acta 80:201-11.

Kelly, SD, MG Newville, L Cheng, KM Kemner, SR Sutton, P Fenter, NC Sturchio, and C Spotl. 2003. "Uranyl Incorporation in Natural Calcite." Environmental Science and Technology 37:1284-87.

Kienzler, B, B Luckscheiter, and S Wilhelm. 2001. "Waste Form Corrosion Modeling Comparison with Experimental Results." Waste Management 21:741-52.

Kienzler, B, V Metz, B Brendebach, N Finck, M Plaschke, T Rabung, J Rothe, and D Schild. 2010. "Chemical Status of U(Vi) in Cemented Waste Forms under Saline Conditions." Radiochimica Acta 98(911):675-84. 10.1524/ract.2010.1768.

Kienzler, B, V Metz, J Lutzenkirchen, E Korthaus, and T Fanghanel. 2007. "Geochemically Based Safety Assessment." Journal of Nuclear Science and Technology 44(3):470-76. 10.3327/jnst.44.470.

Krupka, KM and RJ Serne. 1996. Performance Assessment of Low-Level Radioactive Waste Disposal Facilities: Effects on Radionuclide Concentrations by Cement/Ground-Water Interactions. Report, U.S. Nuclear Regulatory Commission, Washington, D.C.

Langmuir, D. 1997a. Aqueous Environmental Chemistry. Prentice-Hall, Upper Saddle River, NJ. 
Langmuir, D. 1997b. "Aqueous Geochemistry of Uranium." In Aqueous Environmental Chemistry, ed. R McConnin, pp. 494 - 512. Prentice-Hall, Upper Saddle River.

Langmuir, D. 1978. "Uranium Solution-Mineral Equilbria at Low Temperatures with Applications to Sedimentary Ore Deposits." Geochimica et Cosmochimica Acta 42:547-69.

Liu, C, JM Zachara, O Qafoku, JP McKinley, SC Heald, and Z Wang. 2004. "Dissolution of Uranyl Microprecipitates in Subsurface Sediments at Hanford Site, USA." Geochimica Cosmochimica Acta 68(22):4519-37.

Lumpkin, GR and RC Ewing. 1996. "Geochemical Alteration of Pyrochlore Group Minerals: Betafite Subgroup." American Mineralogist 81(9-10):1237-48.

Mann, FM, RJ Puigh II, SH Finfrock, J Freeman, E.J., R Khaleel, DH Bacon, MP Bergeron, PB McGrail, and SK Wurstner. 2001. Hanford Immobilized Low-Activity Waste Performance Assessment: 2001 Version. Report, Pacific Northwest National Laboratory, Richland, WA.

Mattigod, SV, DM Wellman, EA Cordova, CC Bovaird, DJ Skinner, and MI Wood. 2009. Effect of Concrete Wasteform Properties on Radionuclide Migration. Report, Pacific Northwest National Laboratory, Richland, WA.

Matzen, SL, JM Beiriger, PC Torretto, P Zhao, and BE Viani. 2000. "Uranium(Vi) and Neptunium(V) Transport through Fractured, Hydrothermally Altered Concrete." Radiochimica Acta 88:657-64.

McKinley, JP, JM Zachara, C Liu, SC Heald, BI Prenitzer, and BW Kempshall. 2006. "Microscale Controls on the Fate of Contaminant Uranium in the Vadose Zone, Hanford Site, Washington."

Geochimica Cosmochimica Acta 70:1873-87.

McKinley, JP, JM Zachara, J Wan, DE McCready, and SM Heald. 2007. "Geochemical Controls on Contaminant Uranium in Vadose Hanford Formation Sediments at the 200 Area and 300 Area, Hanford Site, Washington." Vadose Zone Journal 6(4):1004-17.

Moll, H, G Geipel, W Matz, G Bernhard, and H Nitsche. 1996. "Solubility and Speciation of (Uo2)2sio4 . 2h2o in Aqueous Systems." Radiochimica Acta 74:3-7.

Moroni, LP and FP Glasser. 1995. "Reactions between Cement Components and U (Vi) Oxide." Waste Management 15(3):243-54.

Morris, DE, PG Allen, JM Berg, CJ Chisholm-Brause, SD Conradson, RJ Donohoe, NJ Hess, JA Musgrave, and CD Tait. 1996. "Speciation of Uranium in Fernald Soils by Molecular Spectroscopic Methods: Characterization of Untreated Soils." Environmental Science and Technology 30(7):2322-31.

Murphy, WM and RB Codell. 1999. "Alternate Source Term Models for Yucca Mountain Performance Assessment Based on Natural Analog Data and Secondary Mineral Solubility." In Scientific Basis for Nuclear Waste Management Xxii, eds. DJ Wronkiewicz and JH Lee, Vol 556, pp. 551-58. Materials Research Society, Warrendale.

Newville, M. 2001. "Ifeffit: Interactive Xafs Anaylsis and Feff Fitting." Journal of Synchrotron Radiation 8:322-24. 
Nguyen, SN, RJ Silva, HC Weed, and J Andrews, John E. 1992. "Standard Gibbs Free Energies of Formation at the Temperature 303.15k of Four Uranyl Silicates: Soddyite, Uranophane, Sodium Boltwoodite, and Sodium Weeksite." Journal of Chemical Thermodynamics 25:359-76.

Nitsche, H. 1991. "Solubility Studies of Transuranium Elements for Nuclear Waste-Disposal - Principles and Overview." Radiochimica Acta 52-3:3-8.

O'Hare, PAG, HR Hoekstra, and DR Frederickson. 1976. "Thermochemistry of Uranium Compounds : Vii. Solution Calorimetry of Alpha and Beta- $\mathrm{Na}_{2} \mathrm{uO}_{4}$, Standard Enthalpy of Formation of Beta- $\mathrm{Na}_{2} \mathrm{UO}_{4}$ and the Enthalpy of the Alpha to Beta Transition at 298.15 K." Journal of Chemical Thermodynamics 8:25558 .

Ollila, K. 1997. "Dissolution of Unirradiated Uo2 Fuel under Oxidizing Conditions: Evaluation of Solubility (Steady State) Limiting Factors (Eq3/6)." In Scientific Basis for Nuclear Waste Management $X x$, eds. WJ Gray and IR Triay, Vol 465, pp. 549-56. Materials Research Society, Warrendale.

Ondrus, P, R Skala, F Veselovsky, J Sejkora, and C Vitti. 2003. "Cejkaite, the Triclinic Polymorph of $\mathrm{Na}_{4}\left(\mathrm{Uo}_{2}\right)\left(\mathrm{Co}_{3}\right)_{3}$ - a New Mineral from Jachymov, Czech Republic." American Mineralogist 88:686-93.

Pennders, RMJ, M Prins, and MJ Frissel. 1985. "The Influence of Environmental Factors on the Solubility of Pu, Am, and Np in Soil-Water Systems." In Speciation of Fission and Activation Products in the Environment, pp. 38-46. Elsevier Science Publishing Co. Inc., New York.

Perez, I, C I., ME Torrero, E Cera, L Duro, and J Bruno. 1997. "Dissolution Studies of Soddyite as a Long-Term Analogue of the Oxidative Alteration of the Spent Nuclear Fuel Matrix." Mat. Res. Soc. Symp. Proc. 465:565-72.

Peterson, RE, ML Rockhold, RJ Serne, PD Thorne, and MD Williams. 2008. Uranium Contamination in the Subsurface beneath the 300 Area, Hanford Site, Washington. Report, PNNL, Richland, WA.

Plotnikov, VI and VI Bannykh. 1997a. "Sorption of Uranium(Vi) by Metal Hydroxides .1. Sorption of Uranium(Vi) by Tetravalent Metal Hydroxides." Radiochemistry 39(2):158-61.

Plotnikov, VI and VI Bannykh. 1997b. "Sorption of Uranium(Vi) by Metal Hydroxides .2. Sorption of Uranium(Vi) by Trivalent Metal Hydroxides." Radiochemistry 39:162-64.

Plotnikov, VI and VI Bannykh. 1997c. "Sorption of Uranium(Vi) by Metal Hydroxides .3. Sorption of Uranium(Vi) by Bivalent Metal Hydroxides and by Mixed Hydroxides of Metals with Different Valence." Radiochemistry 39:165-68.

Pointeau, I, C Landesman, E Giffaut, and P Reiller. 2004. "Reproducibility of the Uptake of U(Vi) onto Degraded Cement Pastes and Calcium Silicate Hydrate Phases." Radiochimica Acta 92:645-50.

Prikryl, JD. 2008. "Uranophane Dissolution and Growth in Cacl2-Sio2(Aq) Test Solutions." Geochimica et Cosmochimica Acta 72(18):4508-20. 10.1016/j.gca.2008.06.022.

Prikryl, JD, A Jain, DR Turner, and RT Pabalan. 2001. "Uranium(Vi) Sorption Behavior on Silicate Mineral Mixtures." Journal of Contaminant Hydrology 47:241-53.

Pryke, DC. 1985a. "Prediction of Actinide Solubilities in the near-Field by a Modeling Study." Nuclear Energy-Journal of the British Nuclear Energy Society 24(3):175-80. 
Pryke, DC. 1985b. "A Simple Model for the Calculation of Actinide Solubilities in a Repository for Nuclear Waste." In Speciation of Fisson and Activation Products in the Environment, pp. 157-61. Elsevier Science Publishing Co. Inc., New York.

Rees, JH. 1985. "The Theoretical Derivation of Solubilities of Long-Lived Radionuclides in Disposal." Journal of Nuclear Materials 130(FEB):336-45. 10.1016/0022-3115(85)90322-8.

Rovira, M, FZE Aamrani, L Duro, I Casas, Jd Pablo, J Bruno, C Domenech, and C Ayora. 2000. "Experimental Study and Modeling of Uranium (Vi) Transport through Ferrous Olivine Rock Columns." Radiochimica Acta 88:665-71.

Sandino, A and J Bruno. 1992. "The Solubility of $\left(\mathrm{Uo}_{2}\right)_{3}\left(\mathrm{Po}_{4}\right)_{2} 4 \mathrm{~h}_{2} \mathrm{O}(\mathrm{S})$ and the Formation of U (Vi) Phosphate Complexes: Their Influence Speciation in Natural Waters." Geochimica et Cosmochimica Acta 56:4135-45.

Sandino, MCA and B Grambow. 1994. "Solubility Equilibria in the U(Vi)-Ca-K-Cl-H2o System: Transformation of Schoepite into Becquerelite and Compreignacite." Radiochimica Acta 66/67:37-43.

Sergeyeva, EI, AA Nikitin, IL Khodakovkiy, and GB Naumov. 1972. "Experimental Investigation of Equilibria in the System $\mathrm{Uo}_{3}-\mathrm{Co}_{2} \mathrm{~h}_{2} \mathrm{O}$ in $25-200^{\circ} \mathrm{C}$ Temperature Interval." Geochemistry International 9:900-10.

Serne, RJ, LL Ames, PF Martin, VL LeGore, CW Lindenmeier, and SJ Phillips. 1992a. Leach Testing of in Situ Stabilization Grouts Containing Additives to Sequester Contaminants. Report, Pacific Northwest Laboratory, Richland, Washington.

Serne, RJ, RO Lokken, and LJ Criscenti. 1992b. "Characterization of Grouted Llw to Support Performance Assessment." Waste Management 12:271-87.

Serne, RJ, WJ Martin, and VL LeGore. 1995. Leach Test of Cladding Removal Waste Grout Using Hanford Groundwater. Report, Pacific Northwest Laboratory, Richland, Washington.

Serne, RJ, WJ Martin, VL LeGore, CW Lindenmeier, SB McLaurine, PFC Martin, and RO Lokken. 1989. Leach Tests on Grouts Made with Actual and Trace Metal-Spiked Synthetic Phosphate/Sulfate Waste. Report, Pacific Northwest Laboratory, Richland, Washington.

Serne, RJ, AT Owen, and CW Lindenmeier. 1996a. Solubility of U(Vi) in Sorbond Lpc Ii Solidified Waste from 183-H Basin. Report, Pacific Northwest National Laboratory, Richland,Washington.

Serne, RJ, D Rai, PF Martin, AR Felmy, L Rao, and S Ueta. 1996b. Leachability of Nd, U, Th, and Sr from Cements in a $\mathrm{Co}_{2}$ Free Atmosphere. In Proceedings of Scientific Basis for Nuclear Waste Management XIX, 459-67 pp. Materials Research Society,

Singer, DM, JM Zachara, and GE Brown. 2009. "Uranium Speciation as a Function of Depth in Contaminated Hanford Sediments - a Micro-Xrf, Micro-Xrd, and Micro- and Bulk-Xafs Study." Environmental Science \& Technology 43(3):630-36. 10.1021/es8021045.

Sowder, AG, SB Clark, and RA Fjeld. 1996. "The Effect of Silica and Phosphate on the Transformation of Schoepite to Becquerelite and Other Uranyl Phases." Radiochimica Acta 74:45-49.

Sposito, G. 1989. The Chemistry of Soils. Oxford University Press, New York, NY. 
Stubbs, JE, LA Veblen, DC Elbert, JM Zachara, JA Davis, and DR Veblen. 2009. "Newly Recognized Hosts for Uranium in the Hanford Site Vadose Zone." Geochimica Et Cosmochimica Acta 73(6):1563-76. 10.1016/j.gca.2008.12.004.

Sutton, M. 1999. "Uranium Solubility, Speciation and Complexation at High Ph." Loughborough University, PhD Doctoral.

Sutton, M, P Warwick, and A Hall. 2003. "Uranium (Vi) Interactions with Opc/Pfa Grout." J. Environ. Monit. 5:922-28.

Sutton, M, P Warwick, A Hall, and C Jones. 1999. "Carbonate Induced Dissolution of Uranium Containing Precipitates under Cement Leachate Conditions." Journal of Environmental Monitoring $1: 177$.

Sylva, RN and MR Davidson. 1979. "The Hydrolysis of Metal Ions. Part 2. Dioxouranium (Vi)." Dalton Transactions 8:465-71.

Sylwester, ER, PG Allen, P Zhao, and BE Viani. 1999. Interactions of Uranium and Neptunium with Cementitious Materials Studied by Xafs. Report, Lawrence Livermore National Laboratory, Livermore, CA.

Tait, CD, RJ Reeder, J Rakovan, DE Morris, EJ Elzinga, DJ Cherniak, and M Nugent. 2002. "Abstracts of the Papers of the American Chemistry Society." Journal of the American Chemical Society (INORG-59).

Tardy, Y and RM Garrels. 1976. "Prediction of Gibbs Energies of Formation .1. Relationships among Gibbs Energies of Formation of Hydroxides, Oxides and Aqueous Ions." Geochimica et Cosmochimica Acta 40(9):1051-56. 10.1016/0016-7037(76)90046-6.

Taylor, HFW. 1990. Cement Chemistry. Academic Press, New York.

Tits, J, N Mace, G Geipel, M Eilzer, and E Wieland. 2008. "U(Vi) Uptake by Calcium Silicate Hydrates." Geochimica et Cosmochimica Acta 72(12):A948-A48.

Um, W, JP Icenhower, CF Brown, RJ Serne, ZM Wang, CJ Dodge, and AJ Francis. 2010.

"Characterization of Uranium-Contaminated Sediments from beneath a Nuclear Waste Storage Tank from Hanford, Washington: Implications for Contaminant Transport and Fate." Geochimica et Cosmochimica Acta 74(4):1363-80. 10.1016/j.gca.2009.11.014.

Um, W, ZM Wang, RJ Serne, BD Williams, CF Brown, CJ Dodge, and AJ Francis. 2009. "Uranium Phases in Contaminated Sediments Below Hanford's U Tank Farm." Environmental Science \& Technology 43(12):4280-86. 10.1021/es900203r.

Vochten, R and LV Haverbeke. 1990. "Transformation of Schoepite into the Uranyl Oxide Hydrates: Becquerelite, Billietite, and Wolsendorfite." Contributions to Mineralogy and Petrology 43:65-72.

Wang, Z, JM Zachara, PL Gassman, C Liu, O Qafoku, W Yantasee, and JG Catalano. 2005.

"Fluorescence Spectroscopy of U(Vi)-Silicates and U(Vi)-Contaminated Hanford Sediment." Geochimica Cosmochimica Acta 69(6):1391-403.

Webb, SM. 2004. "Sixpack: A Graphical User Interface for Xas Anaylsis Using Ifeffit." Physica Scripta:in press. 
Wellman, DM, CC Bovaird, SV Mattigod, KE Parker, RM Ermi, and MI Wood. 2008. Effect of Concrete Wasteform Properties on Radionuclide Migration. Report, Pacific Northwest National Laboratory, Richland, WA.

Wellman, DM, SV Mattigod, BW Arey, MI Wood, and SW Forrester. 2007. "Experimental Limitations Regarding the Formation and Characterization of Uranium-Mineral Phases in Concrete Waste Forms." Cement and Concrete Research.

Wieland, E, N Mace, R Dahn, D Kunz, and J Tits. 2010. "Macro- and Micro-Scale Studies on U(Vi) Immobilization in Hardened Cement Paste." Journal of Radioanalytical and Nuclear Chemistry 286(3):793-800. 10.1007/s10967-010-0742-y.

Wood, MI, R Khaleel, PD Rittman, AH Lu, S Finfrock, RJ Serne, and KJ Cantrell. 1995. Performance Assessment for the Disposal of Low-Level Waste in the 218-W-5 Burial Ground. Report, Westinghouse Hanford Company, Richland, WA.

Wronkiewicz, DJ, JK Bates, TJ Gerding, E Veleckis, and BS Tani. 1991. Leaching Action of Ej-13 Water on Unirradiated $\mathrm{Uo}_{2}$ Surfaces under Unsaturated Conditions at $90^{\circ} \mathrm{C}$ : Interim Report. Report No. ANL91/11, Argonne National Laboratory, Argonne, Illinois.

Wronkiewicz, DJ, JK Bates, TJ Gerding, E Veleckis, and BS Tani. 1992. "Uranium Release and Secondary Phase Formation During Unsaturated Testing of $\mathrm{Uo}_{2}$ at $90^{\circ} \mathrm{c}$." Journal of Nuclear Materials 190:107-27.

Wronkiewicz, DJ, JK Bates, SF Wolf, and EC Buck. 1996. "Ten-Year Results from Unsaturated Drip Tests with $\mathrm{Uo}_{2}$ at $90^{\circ} \mathrm{c}$ : Implications for the Corrosion of Spent Nuclear Fuel." Journal of Nuclear Materials 238:78-95.

Wronkiewicz, DJ, EC Buck, and JK Bates. 1997. "Grain Boundary Corrosion and Alteration Phase Formation During the Oxidative Dissolution of Uo2 Pellets." In Scientific Basis for Nuclear Waste Management Xx, eds. WJ Gray and IR Triay, Vol 465, pp. 519-26. Materials Research Society, Warrendale.

Zachara, JM, CF Brown, J Christensen, E Dresel, C Kelly, J McKinley, RJ Serne, and W Um. 2007. A Site Wide Perspective on Uranium Geochemistry at the Hanford Site. Report, CH2M Hill Hanford Group, Richland, WA.

Zhao, P, PG Allen, ER Sylwester, and BE Viani. 1999. The Partitioning of Uranium and Neptunium onto Hydrothermally Altered Concrete. Report, Lawrence Livermore National Laboratory, Livermore, California. 


\section{Appendix}


Table A.1. Review of Uranium Solubility Values Found in the Literature

\begin{tabular}{|c|c|c|c|c|c|}
\hline Phase & Solution Composition & $\begin{array}{c}\text { Atmospheric } \\
\text { Conditions }\end{array}$ & Test Conditions & Solubility (M) & Reference \\
\hline Pocounorolito & $0.5 \mathrm{M} \mathrm{NaOH}$ & \multirow{4}{*}{$\mathrm{CO}_{2}$-free } & \multirow{4}{*}{$20 \mathrm{C}, 7$ days equilibration } & $4.28 \mathrm{E}-06$ & \\
\hline Becquerelite & water & & & $8.40 \mathrm{E}-06$ & (Attins ot ol 1008) \\
\hline \multirow{2}{*}{$\mathrm{CaUO}_{5}\left(\mathrm{H}_{2} \mathrm{O}\right)_{1.3-1.7}$} & $0.5 \mathrm{M} \mathrm{NaOH}$ & & & $1.74 \mathrm{E}-06$ & (Atkins et al. 1988) \\
\hline & water & & & $0.63 \mathrm{E}-06$ & \\
\hline \multirow{10}{*}{ sodium/calcium urantes } & \multirow{10}{*}{ BFS:OPC water } & \multirow{10}{*}{ nitrogen } & & $2.5 \mathrm{E}-08$ & \multirow{25}{*}{$\begin{array}{c}\text { (Brownsword et al. } \\
1990 \text { ) }\end{array}$} \\
\hline & & & $\mathrm{pH} 12,2$ days equilibration, & $6.2 \mathrm{E}-08$ & \\
\hline & & & $0.05 \mu \mathrm{m}$ Millipore filter & $2.5 \mathrm{E}-08$ & \\
\hline & & & & $2.5 \mathrm{E}-08$ & \\
\hline & & & & $9.8 \mathrm{E}-07$ & \\
\hline & & & & $1.4 \mathrm{E}-07$ & \\
\hline & & & pH 12, 2 days equilibration, & $1.2 \mathrm{E}-07$ & \\
\hline & & & & 8.6E-08 & \\
\hline & & & & $3.4 \mathrm{E}-08$ & \\
\hline & & & $\begin{array}{c}\mathrm{pH} 12,2 \text { days equilibration, Centricon- } \\
30 \text { filter }\end{array}$ & $3.6 \mathrm{E}-06$ & \\
\hline \multirow{11}{*}{ sodium/calcium urantes } & \multirow{11}{*}{ PFA:OPC water } & \multirow{11}{*}{ nitrogen } & & $1.1 \mathrm{E}-06$ & \\
\hline & & & $\mathrm{pH} 11.1,1$ day equilibration, & $3.6 \mathrm{E}-06$ & \\
\hline & & & $0.05 \mu$ um Millipore filter & $4.2 \mathrm{E}-06$ & \\
\hline & & & & $3.6 \mathrm{E}-06$ & \\
\hline & & & & $2.7 \mathrm{E}-06$ & \\
\hline & & & & $9.8 \mathrm{E}-07$ & \\
\hline & & & $\mathrm{pH} 12,2$ days equilibration, & 7.9E-07 & \\
\hline & & & 541 Whatman filter & 4.7E-07 & \\
\hline & & & & $3.9 \mathrm{E}-07$ & \\
\hline & & & & $1.5 \mathrm{E}-07$ & \\
\hline & & & $\begin{array}{l}\mathrm{pH} 12,2 \text { days equilibration, Centricon- } \\
\qquad 30 \text { filter }\end{array}$ & $1.2 \mathrm{E}-06$ & \\
\hline \multirow{4}{*}{ sodium/calcium urantes } & \multirow{4}{*}{ BFS:OPC:L water } & \multirow{4}{*}{ nitrogen } & $\begin{array}{l}\mathrm{pH} 11.4,1 \text { day equilibration, } \\
0.05 \mu \mathrm{m} \text { Millipore filter }\end{array}$ & $\begin{array}{l}2.1 \mathrm{E}-07 \\
3.0 \mathrm{E}-07 \\
2.1 \mathrm{E}-07\end{array}$ & \\
\hline & & & $\begin{array}{l}\mathrm{pH} 11.4,1 \text { day equilibration, } \\
541 \text { Whatman filter }\end{array}$ & $2.1 \mathrm{E}-07$ & \\
\hline & & & $\begin{array}{l}\mathrm{pH} 12,2 \text { day equilibration, } \\
541 \text { Whatman filter }\end{array}$ & 7.1E-08 & \\
\hline & & & $\begin{array}{l}\mathrm{pH} 12,1 \text { day equilibration, Centricon- } \\
30 \text { filter }\end{array}$ & 7E-08 & \\
\hline
\end{tabular}


Table A.1. (contd)

\begin{tabular}{|c|c|c|c|c|c|}
\hline Phase & Solution Composition & $\begin{array}{l}\text { Atmospheric } \\
\text { Conditions }\end{array}$ & Test Conditions & Solubility (M) & Reference \\
\hline \multirow{3}{*}{ U(IV) } & \multirow{3}{*}{ BFS:OPC water } & \multirow{3}{*}{ nitrogen } & $\mathrm{pH} 12$ & $2 \mathrm{E}-07$ & \multirow{3}{*}{ (Ewart et al. 1992) } \\
\hline & & & pH 10.5 & E-07 & \\
\hline & & & pH 13 & E-05 & \\
\hline U(IV) & sand:OPC water & nitrogen & $\begin{array}{l}\mathrm{pH} 12,7 \text { days equilibration, } 0.45 \mu \mathrm{m} \\
\text { filter, } 30000 \text { MWCO filter }\end{array}$ & $2 \mathrm{E}-07$ & $\begin{array}{l}\text { (Greenfield et al. } \\
\text { 1998) }\end{array}$ \\
\hline \multirow{4}{*}{ undetermined $\mathrm{U}(\mathrm{VI})$ phase } & \multirow{4}{*}{ cement leachate solution } & \multirow{4}{*}{$\begin{array}{l}\text { varied } \mathrm{CO}_{3}^{2-} \\
\text { concentrations }\end{array}$} & $\begin{array}{l}\text { maximum solubility observed for } \mathrm{pH} 9, \\
3 \text { days equilibration }\end{array}$ & $5 \mathrm{E}-03$ & \multirow{4}{*}{ (Sutton et al. 1999) } \\
\hline & & & $\begin{array}{l}\text { maximum solubility observed for } \\
\mathrm{pH} 10,3 \text { days equilibration }\end{array}$ & $5 \mathrm{E}-03$ & \\
\hline & & & $\begin{array}{l}\text { maximum solubility observed for } \\
\text { pH } 11,3 \text { days equilibration }\end{array}$ & $2.5 \mathrm{E}-03$ & \\
\hline & & & $\begin{array}{l}\text { maximum solubility observed for } \\
\mathrm{pH} 11.8,3 \text { days equilibration }\end{array}$ & 3.75E-03 & \\
\hline undetermined $\mathrm{U}(\mathrm{VI})$ phase & degraded cement waters & nitrogen & $\begin{array}{l}\mathrm{pH} 10.5,3 \text { days equilibration } \\
\mathrm{pH} 11.8,3 \text { days equilibration }\end{array}$ & $\begin{array}{c}2.4 \mathrm{E}-07 \\
4 \mathrm{E}-06\end{array}$ & (Pointeau et al. 2004 \\
\hline \multirow{2}{*}{ Na-boltwoodite } & \multirow{2}{*}{$\mathrm{NaHCO}_{3} / \mathrm{NaNO}_{3}$ solutions } & \multirow{2}{*}{ ambient } & $\begin{array}{c}\mathrm{pH} 6.8,7 \text { days equilibration, } \\
0 \mathrm{mM} \mathrm{NaHCO} 3\end{array}$ & $3.4 \mathrm{E}-06$ & \multirow{2}{*}{ (Ilton et al. 2006) } \\
\hline & & & $\begin{array}{l}\mathrm{pH} \text { 9.6, } 7 \text { days equilibration, } \\
50 \mathrm{mM} \mathrm{NaHCO} 3\end{array}$ & 7.74E-04 & \\
\hline \multirow{3}{*}{$\mathrm{U}(\mathrm{VI})$} & \multirow{3}{*}{$\begin{array}{c}\text { artificial cement pore water } \\
\text { with } 0.112 \mathrm{M} \mathrm{NaOH} \text { and } \\
0.14 \mathrm{M} \mathrm{KOH} \\
1.5 \mathrm{E}-02 \mathrm{M} \mathrm{Ca}(\mathrm{OH})_{2}, \mathrm{E}-05 \mathrm{M} \mathrm{Si} \\
3 \mathrm{E}-03 \mathrm{M} \mathrm{Ca}, \mathrm{E}-2 \mathrm{M} \mathrm{NaOH}, \\
\mathrm{E}-4 \mathrm{M} \mathrm{Si}\end{array}$} & \multirow{3}{*}{ nitrogen } & $\mathrm{pH}$ 13.3, 7 days equilibration & E-05 & \multirow{3}{*}{ (Tits et al. 2008) } \\
\hline & & & $\mathrm{pH} 12,7$ days equilibration & $4 \mathrm{E}-06$ & \\
\hline & & & $\mathrm{pH} 12,7$ days equilibration & $3 \mathrm{E}-05$ & \\
\hline $\mathrm{Na}_{2} \mathrm{U}_{2} \mathrm{O}_{7} \cdot \mathrm{H}_{2} \mathrm{O}$ & $\begin{array}{l}\mathrm{MgCl} \text { brine } \\
\mathrm{NaCl} \text { brine }\end{array}$ & ambient & $\begin{array}{l}\mathrm{pH} 7-10.5,5-18 \text { years equilibration } \\
\mathrm{pH} 11-12,5-18 \text { years equilibration }\end{array}$ & $\begin{array}{l}8 \mathrm{E}-09-5 \mathrm{E}-07 \\
2 \mathrm{E}-09-4 \mathrm{E}-07\end{array}$ & $\begin{array}{l}\text { (Kienzler et al. 2010 } \\
\text { Kienzler et al. 2007) }\end{array}$ \\
\hline $\mathrm{U}(\mathrm{VI})$ & artificial cement pore water & nitrogen & $\mathrm{pH} 13.3$ & $6 \mathrm{E}-06$ & (Wieland et al. 2010) \\
\hline
\end{tabular}


Table A.2. Equilibrium Concentrations of Primary Elements in Solubility Study

\begin{tabular}{|c|c|c|c|c|c|c|}
\hline \multicolumn{7}{|c|}{ Soddyite } \\
\hline Pore water & Initial $\mathrm{pH}$ & Final pH & [U] & {$[\mathrm{Ca}]$} & {$[\mathrm{P}]$} & {$[\mathrm{Si}]$} \\
\hline 9:1 BFS/OPC & 12.2 & 6.0 & $2.21 \mathrm{E}-04$ & $1.99 \mathrm{E}-05$ & N/A & $7.01 \mathrm{E}-04$ \\
\hline OPC/BFS/L & 12.1 & 6.5 & 4.11E-06 & 3.62E-05 & $1.66 \mathrm{E}-06$ & $6.04 \mathrm{E}-05$ \\
\hline Harwell & 12.0 & 5.0 & $5.02 \mathrm{E}-06$ & $2.43 \mathrm{E}-03$ & $5.28 \mathrm{E}-06$ & $3.85 \mathrm{E}-04$ \\
\hline $\mathrm{OPC} / \mathrm{L}$ & 12.0 & 10.0 & $1.06 \mathrm{E}-06$ & $7.98 \mathrm{E}-04$ & $2.44 \mathrm{E}-06$ & $2.76 \mathrm{E}-04$ \\
\hline SRPC/L & 12.5 & 5.0 & $2.03 \mathrm{E}-04$ & $6.99 \mathrm{E}-05$ & $3.42 \mathrm{E}-06$ & $3.06 \mathrm{E}-04$ \\
\hline \multicolumn{7}{|c|}{ Becquerelite } \\
\hline Pore water & Initial $\mathrm{pH}$ & Final pH & {$[\mathrm{U}]$} & {$[\mathrm{Ca}]$} & {$[\mathrm{P}]$} & {$[\mathrm{Si}]$} \\
\hline 9:1 BFS/OPC & 12.2 & 7.5 & $5.77 \mathrm{E}-07$ & $2.55 \mathrm{E}-04$ & N/A & $1.76 \mathrm{E}-05$ \\
\hline OPC/BFS/L & 12.1 & 9.5 & $1.10 \mathrm{E}-06$ & $3.92 \mathrm{E}-05$ & 4.61E-06 & 4.99E-06 \\
\hline Harwell & 12.0 & 9.0 & 8.95E-08 & $4.48 \mathrm{E}-03$ & $1.94 \mathrm{E}-06$ & $8.12 \mathrm{E}-06$ \\
\hline $\mathrm{OPC} / \mathrm{L}$ & 12.0 & 11.5 & 8.80E-09 & $1.00 \mathrm{E}-02$ & $3.03 \mathrm{E}-06$ & $1.53 \mathrm{E}-05$ \\
\hline SRPC/L & 12.5 & 7.5 & $8.63 \mathrm{E}-08$ & $5.45 \mathrm{E}-04$ & $4.78 \mathrm{E}-06$ & $3.40 \mathrm{E}-06$ \\
\hline \multicolumn{7}{|c|}{ Uranophane } \\
\hline Pore water & Initial $\mathrm{pH}$ & Final pH & [U] & {$[\mathrm{Ca}]$} & {$[\mathrm{P}]$} & {$[\mathrm{Si}]$} \\
\hline 9:1 BFS/OPC & 12.2 & 9.0 & $2.19 \mathrm{E}-06$ & $3.36 \mathrm{E}-04$ & $2.32 \mathrm{E}-06$ & $2.66 \mathrm{E}-03$ \\
\hline OPC/BFS/L & 12.1 & 10.0 & $1.92 \mathrm{E}-06$ & $1.29 \mathrm{E}-04$ & $1.64 \mathrm{E}-06$ & $1.56 \mathrm{E}-02$ \\
\hline Harwell & 12.0 & 9.0 & 2.44E-08 & $1.82 \mathrm{E}-03$ & $1.14 \mathrm{E}-06$ & $3.12 \mathrm{E}-03$ \\
\hline OPC/L & 12.0 & 9.0 & $2.04 \mathrm{E}-08$ & $4.81 \mathrm{E}-04$ & $1.78 \mathrm{E}-06$ & $2.12 \mathrm{E}-03$ \\
\hline SRPC/L & 12.5 & 9.0 & $3.81 \mathrm{E}-06$ & $6.73 \mathrm{E}-04$ & 2.93E-06 & $2.61 \mathrm{E}-03$ \\
\hline \multicolumn{7}{|c|}{ Autunite } \\
\hline Pore water & Initial $\mathrm{pH}$ & Final $\mathrm{pH}$ & [U] & {$[\mathrm{Ca}]$} & {$[\mathrm{P}]$} & {$[\mathrm{Si}]$} \\
\hline 9:1 BFS/OPC & 12.2 & 7.5 & $4.93 \mathrm{E}-06$ & $1.21 \mathrm{E}-04$ & $4.02 \mathrm{E}-05$ & $1.99 \mathrm{E}-05$ \\
\hline OPC/BFS/L & 12.1 & 8.0 & $1.74 \mathrm{E}-06$ & $1.92 \mathrm{E}-05$ & 3.39E-04 & $1.13 \mathrm{E}-05$ \\
\hline Harwell & 12.0 & 6.5 & $1.53 \mathrm{E}-08$ & $1.06 \mathrm{E}-03$ & $2.98 \mathrm{E}-06$ & $8.72 \mathrm{E}-06$ \\
\hline $\mathrm{OPC} / \mathrm{L}$ & 12.0 & 6.0 & $2.77 \mathrm{E}-07$ & $5.88 \mathrm{E}-05$ & $2.77 \mathrm{E}-06$ & $5.88 \mathrm{E}-06$ \\
\hline SRPC/L & 12.5 & 5.5 & $4.20 \mathrm{E}-07$ & $1.28 \mathrm{E}-04$ & $6.65 \mathrm{E}-06$ & $9.17 \mathrm{E}-06$ \\
\hline
\end{tabular}




\section{Distribution}

No. of

Copies

OFFSITE
No. of

Copies

ONSITE

\# $\quad$ Pacific Northwest National Laboratory

Distr. 1 



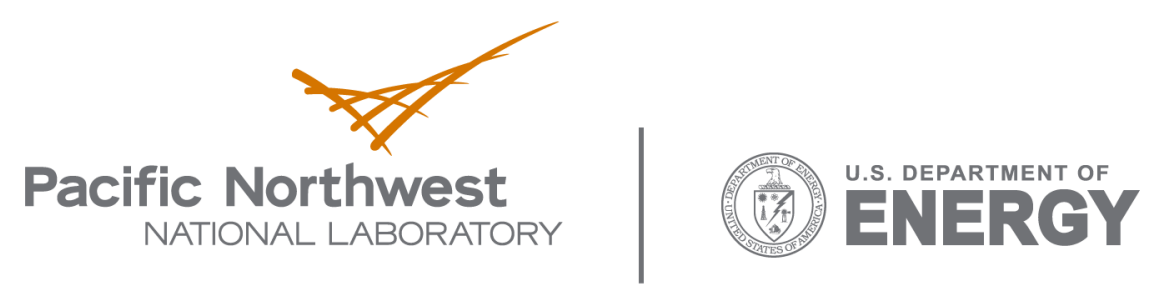

902 Battelle Boulevard

P.O. Box 999

Richland, WA 99352

1-888-375-PNNL (7665)

www.pnl.gov 